
cartografia de múltiplos corpos 


\section{Dança e diferença}


UNIVERSIDADE FEDERAL DA BAHIA

Reitor

Dora Leal Rosa

Vice-Reitor

Luiz Rogério Bastos Leal

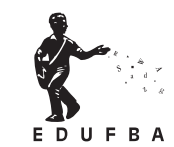

EDITORA DA UNIVERSIDADE FEDERAL DA BAHIA

Diretora

Flávia Goullart Mota Garcia Rosa

Conselho Editorial

Alberto Brum Novaes

Angelo Szaniecki Perret Serpa

Caiuby Alves da Costa

Charbel Ninõ El-Hani

Cleise Furtado Mendes

Dante Eustachio Lucchesi Ramacciotti

Evelina de Carvalho Sá Hoisel

José Teixeira Cavalcante Filho

Maria Vidal de Negreiros Camargo 


\title{
Dança e diferença cartografia de múltiplos corpos
}

\author{
Lúcia Matos
}

EDUFBA

Salvador, 2012 
2012, Lúcia Helena Alfredi de Matos. Direitos para esta edição cedidos à Edufba. Feito o Depósito Legal.

\author{
Projeto Gráfico \\ Angela Garcia Rosa \\ Amanda Santana da Silva \\ Capa \\ Angela Garcia Rosa \\ Editoração e arte-final \\ Gabriel Cayres \\ Revisão \\ EDUFBA \\ Normalização \\ Lucas Esperança
}

Sistema de Bibliotecas - UFBA

Matos, Lúcia.

Dança e diferença : cartografia de múltiplos corpos / Lúcia

Matos. - Salvador : EDUFBA, 2012.

184 p. - (Coleção pesquisa em artes).

ISBN 978-85-232-0964-3

I. Dança. 2. Corpo humano. 3. Pós-modernismo. I. Título. II. Série.

CDD - 793.3

\title{
Editora filiada à
}
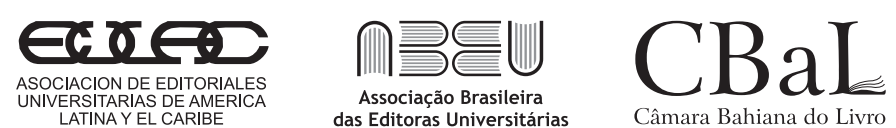

EDUFBA

Rua Barão de Jeremoabo, $s / n$, Campus de Ondina, 40170-II5 Salvador-BA Brasil

Tel/fax: (7I)3283-6I60/3283-6I64

www.edufba.ufba.br | edufba@ufba.br 
Dedico este livro aos meus pais Sylvio e Deolinda (in memorian) e a Guiga, Rafael e Lucas.

A todos pensadores e artistas nômades que, de uma forma ou de outra, contribuem para o emergir da diferença. 



\section{AGRADECIMENTOS}

Minha profunda gratidão aos artistas e grupos de dança que partilharam suas experiências e possibilitaram a efetivação da pesquisa de doutorado, que resulta neste livro.

Agradeço aos meus ex-professores, orientadores e ex-alunos, pelas ideias e pelo compartilhamento de conhecimento. Aos amigos, e em especial Teresa Oliveira, pelo apoio e comentários sobre meus escritos.

Ao CNPq, pela Bolsa de doutoramento e à EDUFBA pelo apoio à publicação deste livro. 



\section{SUMÁRIO}

PREFÁCIO

INTRODUÇÃO - CONECTANDO TERRENOS FRACTAIS:

A MEMÓRIA ENCARNADA DE UM PROCESSO INVESTIGATIVO

SOLOS MOVEDIÇOS: A DANÇA, O CORPO E O CENÁRIO

Diferenciando a diferença

CARTOGRAFANDO ESPAÇOS FRONTEIRIÇOS:

A PRODUÇÃO DA DANÇA INCLUSIVA (DISABLED DANCE) NO BRASIL

Disabled Dance ou dança momentaneamente inclusiva 
EXPLORANDO (RE)CONFIGURAÇÕES TERRITORIAIS E ESTÉTICAS NA DANÇA

Cia. de dança Ekilíbrio 85

O contexto do grupo 88

Processos de criação e suas relações com diferentes corpos 91

Limites Companhia de Dança 104

Pulsar Cia. de Dança

121

Grupo X de Improvisação em Dança

139

Cantos

149

UMA CARTOGRAFIA MUTANTE PARA TRANSITÓRIAS CONCLUSÕES

REFERÊNCIAS 


\section{PREFÁCIO}

Se lançarmos um olhar panorâmico sobre a cena contemporânea da dança, veremos uma infinidade de processos e configurações estéticas circulando em direções múltiplas, através de colaborações dialógicas, transdisciplinares e mesmo transculturais, onde conceitos de arte, ciência, tradição, inovação, pessoalidade, coletividade, corpo, ambiente, dentre tantos outros, se aproximam, se relacionam, se confrontam e se transformam mutuamente. Esta publicação oferece uma perspectiva esclarecedora sobre alguns aspectos que marcam este contexto de pluralidade, de diferenças e de transitoriedades.

Voltando seu olhar para possíveis territorialidades estéticas geradas a partir de propostas coreográficas que incluem dançarinos com e sem deficiências, Lúcia Matos oferece uma perspectiva inovadora de investigação acadêmica em Dança, não apenas por refletir sobre questões que analisam e relacionam estética coreográfica e investigação corporal, mas também pelo uso da pesquisa interpretativa como encaminhamento metodológico do estudo.

A relação entre deficiência/diferença corporal e dança tem sido objeto de interesse da autora, desde seus estudos de mestrado, seguidos pelos 
de doutorado, que tive o prazer de orientar, cuja tese foi adaptada para esta publicação. Portanto, é com autoridade, responsabilidade acadêmica e compromisso artístico que Lúcia compartilha com o leitor suas indagações e reflexões acerca de conceitos como corpo, diferença, processos identitários, participação investigativa, políticas de inclusão, encaminhamentos e protocolos de composição em dança e estética coreográfica, tratados de forma entrelaçada em redes dialógicas e associativas.

Há alguns anos tive a oportunidade de assistir a um espetáculo de dança em Nova lorque que incluía, em seu elenco, dançarinos com e sem deficiência (no caso, deficiência visual). O projeto havia recebido subsídios significativos de apoio à execução e montagem do trabalho. Desapontada fiquei ao constatar o grau de dependência dos dançarinos com deficiências ao serem manipulados por aqueles sem deficiências numa atitude de submissão à estética vigente construída por corpos tradicionalmente normativos em Dança. Ainda hoje, não é incomum, como aponta a autora, encontrarmos trabalhos desenvolvidos por criadores sem deficiências e adaptados àqueles com deficiências, numa negação às habilidades individuais de construção e colaboração coreográfica. Evidencia-se aí a deficiência e não a "artisticidade" do intérprete. Tais abordagens, nada têm a oferecer à perspectiva deste livro, tampouco à experiência criativa de dançarinos com deficiências, uma vez que descartam possibilidades de autonomia criativa e investigativa frente às realidades corporais de seu elenco. Felizmente, estudos aqui desenvolvidos apontam para abordagens diferenciadas sugerindo novas territorializações estéticas, advindas de corpos diferentes, em processos de construção colaborativa e autônoma. Questiona-se, assim, antigos preconceitos e estigmas acerca da diferença, da alteridade, e da participação de artistas com deficiências em sua relação corpórea e estética com a Dança.

Ao discutir relações de corporalidade e produção estética em dança, a autora coloca em foco protocolos metodológicos de construção e colaboração coreográfica centrados em investigações que ocorrem no/pelo corpo. Observa como novas territorializações estéticas podem advir de experimentações e explorações que têm o corpo como eixo primeiro de investigação criativa e compositiva. Esta relação intrínseca entre investiga- 
ção criativa centrada e desenvolvida no/pelo corpo e composição coreográfica me remete ao termo "corporeografia", conceito que vem sendo amplamente discutido no âmbito do PROCEDA' É em ritmo de divergência estética que proposições que incluem pluralidades, diferenças (no sentido deleuziano de uma diferença que se faz diferenciando) e autonomia artística, potencialmente presentes em trabalhos que incluem múltiplos corpos (investigativos e dançantes) em seus elencos, surgem como um fator exponencial de novas territorializações estéticas em dança.

Considerando a escassez de produção bibliográfica na área, esta publicação, por sua temática e qualidade de discussão, assume grande relevância para a Dança, oferecendo contribuição significativa para seu desenvolvimento acadêmico e artístico. Apesar de enfocar trabalhos realizados com dançarinos com e sem deficiência, este livro apresenta e discute conceitos e ações que extrapolam o universo de seu objeto imediato de estudo, oferecendo informações relevantes a todos os que com dança trabalham: dançarinos, coreógrafos, críticos, professores e pesquisadores em dança. Interessa ainda àqueles que direta ou indiretamente lidam com artes, com políticas públicas e de inclusão, com educação, com sociologia, com estética e outras áreas afins.

Para finalizar, conforme escreve a autora em sua apresentação, "os significados encontrados nesta investigação foram resultantes de uma dialogia e polifonia de vozes, numa articulação entre a voz da pesquisadora, as dos sujeitos investigados, aquelas emergentes das obras coreográficas e as dos teóricos." Diria que, a partir de agora, a orquestra de significados deste estudo incorpora também outras, diferentes e inúmeras vozes: a de vocês, leitores.

Cape Cod - USA, 12 de maio de 2010

Leda Muhana lannitelli

Coreógrafa, Professora Titular e Pesquisadora em Dança

Programa de Pós-Graduação em Dança

Escola de Dança da Universidade Federal da Bahia 


\section{NOTAS}

I Processos Coreporeográficos e Educacionais em Dança. Grupo de Pesquisa (PROCEDA) vinculado ao Programa de Pós-Graduação em Dança da Universidade Federal da Bahia, o qual, juntamente com a autora, coordeno. 


\section{INTRODUÇÃO}

\section{Conectando terrenos fractais: a memória encarnada de um processo investigativo}

O processo de indagar, conhecer e escrever sobre um tema coloca-nos o tempo todo em contato com nossos limites no processo de conhecer. Deleuze (1988) explana que, ao escrevermos, imaginamos ter algo a dizer e não temos como evitar abordar temáticas sobre aquilo que mal sabemos ou que não sabemos. Em suas palavras, "só escrevemos na extremidade de nosso próprio saber, nesta ponta extrema que separa nosso saber e nossa ignorância e que transforma um no outro. É só deste modo que somos determinados a escrever." (DELEUZE, 1988, p. 18)

Nesse sentido, toda a tessitura que envolve o processo de investigação da mais simples à mais complexa questão, até chegar ao formato final da redação - torna-se essencial para que se possam encontrar pistas e respostas, mesmo que estas sejam parciais, para nossas lacunas de conhecimento. 
Nessa via, optei por desvelar, nestas primeiras páginas, aspectos do processo de configuração da pesquisa realizada para o Doutorado no Programa de Pós-Graduação em Artes Cênicas da UFBA (2006), cujo resultado, de forma aproximada, corresponde ao conteúdo deste livro.

O corpo vem sendo o foco das reflexões e, após anos de trabalho como professora de balé clássico e dança moderna para crianças e jovens em academias particulares, aliada à incursão no trabalho de formação de docentes no ensino público profissionalizante, iniciei uma nova experiência de docência com crianças e adolescentes Surdos', em 1992, instigada pela rica expressividade gestual de sua língua , a Língua Brasileira de Sinais (LIBRAS). Mesmo não tendo no corpo a experiência de ser uma pessoa com deficiência, questões relacionadas à dança, corpo, diferença e deficiência despertavam indagações. A continuidade do trabalho de dança com jovens surdos me levou à busca pelo aprofundamento dos estudos nessa área, tornando-se foco da pesquisa de mestrado intitulada "Múltiplos olhares sobre o corposurdo: a corporeidade do adolescente surdo no ensino da dança." (MATOS, 1998)

Mantendo como tema o corpo, a pesquisa de doutorado centrou-se no mapeamento de grupos de dança que tinham em seu elenco dançarinos com e sem deficiência ${ }^{2}$ e na análise de obras coreográficas de quatro grupos selecionados dentro desse mapeamento. Assim, foi elaborada uma cartografia que apresentou como novas territorializações estéticas estão sendo tecidas na dança contemporânea a partir de processos generativos que articulam identidades, fisicalidades, diferenças e criam configurações polifônicas e novos sentidos no/pelo corpo que dança.

O termo cartografia é aqui abordado como espaço de (re)apropriação, a partir da perspectiva de Cunha e Silva (1999a), na medida que o corpo que dança, ao investir no movimento, transgride o seu lugar, transforma o espaço e gera mudanças no próprio corpo. Assim, ao focar a análise de trabalhos coreográficos com múltiplos corpos dançantes, suas diferenças impressas no movimento têm a possibilidade de (re)organizarem-se, construindo novas relações no processo de criação e novos sentidos para/com o corpo, resultando em uma rede complexa de significação. É nesse sentido que Cunha e Silva (1999b, p. 24) afirma que “o corpo que dança é, por isso, 
um corpo cartografante: os lugares por onde passa organizam-se como um mapa. E o mapa, ao revelar o corpo através dos lugares por onde passou, emerge como uma metáfora do conhecimento."

Assim, neste livro, aborda-se a cartografia dos múltiplos corpos dançantes como um mapa mutante, não linear e não-conclusivo, que pode apresentar paradoxos, múltiplas forias e disforias, no qual o corpo se inscreve no espaço ao mesmo tempo em que o espaço se inscreve no corpo. Assim, esse processo de corporificação (embodiment), de re-singularização, na acepção de Guatarri, do corpo que dança pode construir novas formas de significação do ser social em seu agir, pensar e sentir, bem como abrir territórios na dança tanto no que se refere à produção estética, quanto ao treinamento e à formação.

Para mapear os grupos de dança, no Brasil, que atendiam ao perfil delimitado pela pesquisa foi realizada uma sondagem, via questionário. Até 2005 foi possível fazer um levantamento de 55 grupos, o que implica que no cenário nacional ainda são poucos os grupos independentes que atuam na dança com elencos formados por bailarinos com e sem deficiência. Dentro desse levantamento, foram selecionadas quatro unidades de análise para este estudo - Grupo X de Improvisação em Dança (BA), Pulsar Cia. de Dança (RJ), Limites Cia. de Dança (PR) e Cia. de Dança Ekilíbrio (MG), todos eles com produção autodefinida como de dança contemporânea.

O percurso traçado na investigação buscou articular a construção de um horizonte teórico que tivesse em seu arcabouço um olhar plural e transdisciplinar sobre o objeto de estudo e o processo heurístico da pesquisa. Assim, no processo de investigação optou-se pelo estado de indagação, na busca de novas articulações que se aproximassem do paradigma da complexidade (MORIN, 1996) e que favorecessem a construção do pensamento como um processo, como agenciamentos, já que, de acordo com a acepção deleuziana, os conceitos precisam ser (re)inventados e essa perspectiva só é possível através de confrontos, agenciamentos, os quais produzem novas possibilidades de conexões ou interpretações.

Para a articulação de terrenos fractais ${ }^{3}$ e a construção de um pensamento como um processo transformador, utilizou-se a perspectiva da pesquisa 
interpretativa. McNamara (1999) apresenta a pesquisa interpretativa como um campo de investigação transdisciplinar que busca examinar o significado "textual” e como esse significado é construído. É importante salientar que essa autora define como texto toda construção simbólica de sentidos, o que inclui as configurações e processos da dança, sejam eles, imagens, escritos, falados ou dançados. Na perspectiva dessa autora, o significado do texto emerge do próprio processo de interpretação, o que sugere a importância de compreendermos o corpo como um produtor de sentidos e de metáforas e se é enfatizado o valor da compreensão da essência do fenômeno e seus variados cenários.

Nesse sentido, os significados encontrados nesta investigação foram resultantes de uma dialogia e polifonia de vozes, numa articulação entre a voz da pesquisadora, as dos sujeitos investigados, aquelas emergentes das obras coreográficas e as dos teóricos.

A perspectiva da pesquisa interpretativa foi fundamental para que se pudesse perceber nos produtos artísticos de cada um dos grupos pesquisados suas especificidades e suas formas de ações estratégicas e significações. Para tanto, esse tipo de interpretação necessitou ser baseada em um pensamento complexo que buscasse "metapontos de vista", objetivando abandonar o relativismo, a partir da premissa de que "é necessário conhecer a si mesmo para conhecer o objeto (curva auto-observável)." (MORIN, I996, p. 28I)

Os trabalhos artísticos dos grupos Ekilíbrio, Pulsar, Limites e $\mathrm{X}$ foram analisados a partir das impressões da apreciação dos espetáculos e com a análise dos registros dos mesmos em vídeo. Esse instrumento foi utilizado, também, como um “alimentador de memória”, já que todos os espetáculos foram assistidos in loco em espaços teatrais, o que contribuiu para minimizar os prejuízos que essa técnica traz para a dança, ao transformá-la de tridimensional para bidimensional.

Foram criadas unidades e categorias de análise que surgiram no processo e serviram de guias para a análise de cada obra coreográfica. As informações encontradas nesse processo foram confrontadas e dialogadas com as teorias e com os demais dados obtidos, tanto através das entrevistas grupais e semi-estruturadas realizadas com coreógrafos, dançarinos e di- 
retores dos grupos em questão, somadas às correspondências realizadas por correio eletrônico, como das observações feitas durante a apreciação dos produtos artísticos e das fontes documentais como fotos, programas, críticas e releases de seus trabalhos.

A articulação entre a observação, a análise da obra coreográfica e a fundamentação teórica se deu num processo dialógico e, como afirma Fernandes (2000b, p. 238, grifo do autor),

[...] esse processo é mutável e organizado gradualmente. A lógica intrínseca de uma obra artística sendo analisada aos poucos invade e determina o método apropriado para sua análise, ou reorganiza um método escolhido a priori. O autor da pesquisa passa a ser um re-criador, tanto quanto o da obra analisada. Assim, a pesquisa em artes cênicas é sempre uma core-grafia, de-compondo ${ }^{4}$ ideias e matéria.

Os diferentes diálogos teóricos utilizados neste trabalho possibilitaram uma organização imagética da pesquisa indo além do fractal, buscando articulações rizomáticas, imagem esta que possibilitou perceber de uma forma não linear a complexidade, a imprevisibilidade e a dinâmica de um sistema, e as retroalimentações que são estabelecidas com o contexto. Essa organização tornou-se importante para que se tecessem diferentes articulações e dialogias com noções-chave como corpo, dança contemporânea, diferença e deficiência.

A estrutura do livro está tecida a partir da visão de uma cartografia como um mapa mutante, que aqui apresenta um recorte espaço-temporal relacionado ao período da pesquisa. Nesse sentido, os capítulos também apresentam relações transitórias estabelecidas entre os corpos e os espaços, no sentido de desterritorializações.

No primeiro capítulo Solos movediços: a dança, o corpo e o cenário contemporâneo, são analisados a ambiência da dança e do corpo na contemporaneidade, partindo do conceito chave de diferença proposto pelo pensamento do filósofo Gilles Deleuze, agregando a esse conceito contribuições do campo dos Estudos Culturais (HALL, I997, 2000; SILVA, 2000), 
que possibilitaram conexões com o corpo que dança e com os trabalhos de autores como Albright (1997), Foster (1996, 1997), Desmond (1997) e Kuppers (2004). Como área específica, também é apresentada as contribuições dos Disability Studies (BARNES, 2003; JOHNSTONE, 2004; SKLIAR, 1999), um novo campo interdisciplinar que busca apreender como fatores sociais, culturais, políticos e econômicos definem a deficiência e a diferença.

Ao discorrer sobre a condição da deficiência no segundo capítulo intitulado Das grutas, dos guetos, às superfícies dissimuladas, apresenta-se, de forma sucinta, a representação da deficiência na arte e a inserção do artista com deficiência, principalmente a partir da arte moderna, quando se vê, de uma forma mais evidente, uma possibilidade de associação da deficiência à categoria estética do grotesco. Assim, discute-se a visibilidade da pessoa com deficiência na arte em conexão com conceitos como normalidade, grotesco e freak.

No terceiro capítulo Cartografando espaços fronteiriços: a produção da dança inclusiva (disabled dance) no Brasil, é apresentado dados referentes ao mapeamento de grupos de dança no Brasil que possuem em seu elenco dançarinos com deficiência, e analisa-se as representações que estiveram presentes em obras coreográficas integrantes do $I^{\circ}$ Festival Internacional Arte sem Barreiras. ${ }^{5}$ (PUC-MG, 2002)

Os resultados analíticos das obras coreográficas dos quatro grupos selecionados como estudo de caso, salvaguardando suas especificidades, estão presentes no quarto capítulo Explorando (re)configurações territoriais e estéticas na dança.

Em Uma cartografia mutante para transitórias conclusões, chega-se as considerações finais, as quais tecem inferências a partir da análise dos grupos estudados, de possíveis desdobramentos e aponta lacunas decorrentes do estudo realizado.

O resultado da pesquisa, agora apresentado em forma de livro, também abarcou os fluxos, refluxos e contra-fluxos e, analogicamente como enfatiza McNamara ( 1999), do mesmo modo que um coreógrafo muda suas ideias iniciais no decorrer do processo de criação, o pesquisador também deve estar atento e aberto para que no processo de interpretação - mesmo 
quando comece a compreender o fenômeno investigado - perceba que novos dados e conhecimentos podem surgir e conduzi-lo para direções inesperadas, o que torna possível a conexão de terrenos fractais. Foi por esse viés que se trilhou os caminhos aqui apresentados.

\section{NOTAS}

I Usamos o termo "Surdo" procurando situar esses sujeitos como um grupo social que possui uma cultura própria, sendo essa nomenclatura adotada pelos próprios Surdos. Essa perspectiva não pretende camuflar os diferentes níveis de déficit sensorial auditivo, mas procura percebê-los como sujeitos sociais, com características peculiares.

2 Adotamos o termo pessoa ou bailarino com deficiência, ao invés de usar outros termos utilizados pelo discurso oficial como pessoas portadoras de necessidades especiais ou pessoas portadoras de deficiência. Muitas organizações de pessoas com deficiência defendem a tese de que o termo deficiência não deve ser vinculado diretamente ao sujeito (pessoa deficiente), pois provoca uma leitura desviante, estigmatizando a pessoa como um todo incapacitado. Por outro lado, o termo portador enfatiza algo móvel como se a deficiência fosse um acessório. Muitos grupos preferem se identificar em relação a aspectos de sua especificidade social e cultural como Surdos, não-visuais, cadeirantes, dentre outros, o que traz a discussão da deficiência para o âmago da estrutura social.

3 Fractais são estruturas geométricas complexas cujas propriedades, em geral, repetem-se em qualquer escala. (HOUAISS, 200I, p. 1383) Analogicamente conceituo aqui como terrenos fractais os campos teóricos possíveis de articulações em rede, que são simultaneamente unos e plurais, apresentando permanências e transformações e, desse modo, podem gerar conexões rizomáticas.

4 Jogo gráfico da autora.

5 Este Festival fez parte do I Congresso Internacional de Artes Sem Barreiras, organizado pelo Programa Arte sem Barreiras da FUNARTE e pela Universidade Católica de Minas - PUC-Minas, foi realizado em Belo Horizonte, no período de 17 a23 de novembro de 2002. 



\section{SOLOS MOVEDIÇOS: A DANÇA, O CORPO E O CENÁRIO CONTEMPORÂNEO}

$\mathrm{Na}$ área da Dança, alguns pesquisadores que constroem investigações sobre a corporalidade e a ambiência contemporânea (ALBRIGHT, 1997; DESMOND, 1997; FOSTER, 1996; GREINER, 2003; IANNITELLI, 2000; KATZ, 1994) vêm contestando visões hegemônicas, dicotômicas e mecanicistas que concebem o corpo como um instrumento ou um meio, no que se refere ao seu treinamento e/ou ao seu processo de criação, bem como sustentam, em seus discursos, a impossibilidade de separações entre a rede complexa de negociações que se estabelece entre a fisicalidade, a subjetividade, a cultura e a identidade dos corpos dançantes.

Apesar dessas novas contribuições, a concepção de corpo mais comumente encontrada nas práticas e nas produções artísticas em Dança ainda reflete o corpo surgido/construído a partir dos valores renascentistas, os quais foram alicerces conceituais para o projeto iluminista: um corpo técnico, clássico, individual e virtuoso. 
Mesmo com as mudanças ocorridas no início do século $X X$ com a dança moderna, que já naquela época apresentou novas formulações de corpo e de dança, muitas das propostas de inovadores dessa arte foram transformadas em meras técnicas corporais mecânicas, distanciadas dos fundamentos filosófico e artístico, que deram origem a esse movimento. (WOLFF, 1997; THOMAS, 1995)

Somente com a dança pós-moderna, a partir daquela produzida nos anos 1960/70, foi que surgiram propostas que se direcionaram ao experimentalismo e à incorporação dos movimentos do cotidiano às criações coreográficas, muitas vezes assumindo posicionamentos críticos em relação ao contexto sociocultural e político.

Assim, começaram a ocorrer, mais enfaticamente, algumas experiências com corpos não treinados, procurando refutar o autoritarismo na concepção de corpo, o que abriu caminho para que a dança começasse a incorporar, em suas produções, "um corpo múltiplo, multiforme e capaz, literalmente, de ser feito de diferentes expressões de corpos”. (FOSTER, 1997, p. 256, tradução nossa)

Hoje, uma das correntes da dança contemporânea engajada em teorias críticas culturais procura enfocar o corpo dançante e as representações seja em relação a gênero, etnia ou mesmo habilidade física - que o corpo do(a) dançarino(a) traz para a dança como resultado de suas experiências diárias no contexto social e cultural.

Essas mudanças advindas da dança contemporânea estão intimamente conectadas com as transformações surgidas no contexto pós-moderno. Apesar de existirem várias linhas teóricas que analisam essa condição pós-moderna (HARVEY, 1992), é quase consenso que vivemos uma crise paradigmática e, como enfatiza Maffesoli (1998) em sua perspectiva sociológica compreensiva, estamos em busca de um novo modo ou modos de estar-junto social.

$\mathrm{Na}$ acepção desse autor, a modernidade sustentou-se numa homogeneização, delimitada por uma ordem epistemológica e que tem em sua raiz uma tríade: o indivíduo - sujeito autônomo do projeto das luzes que implicou no individualismo -, a história - visão de um progresso projetivo e linear, levando à sucessão da historiografia dos acontecimentos pela 
história triunfante - e a razão - racionalidade instrumental e desenvolvimento científico e tecnológico.

Esse cenário da modernidade, de acordo com Maffesoli (1998), leva-nos à compreensão da emergência do que é denominado como pós-modernismo, pois sua forma e hierarquização de composição não atendiam mais aos anseios da sociedade pós-industrial.

Ao entrar na discussão da configuração da pós-modernidade, Maffesoli ( 1998 ) enfatiza que sua (re)composição envolve características que se acreditava estarem superadas, as quais se apresentam levemente modificadas - crescimento em forma de espiral. Em sua definição provisória da pós-modernidade, o autor aborda a sinergia de fenômenos arcaicos e do desenvolvimento tecnológico, que envolvem o retorno ao local - o local serve de vínculo - , a importância da tribo - proximidade social destituída de hierarquias/socialidade - e a colagem mitológica - fim das grandes narrativas.

Essa concepção de pós-modernidade faz surgir uma nova base epistemológica, na qual a tríade indivíduo, história e razão “cedem, mais ou menos, lugar à fusão afetual encarnada no presente em torno de imagens de comunhão.” (MAFFESOLI, 1998, p. 12) O indivíduo cede à persona, com identidades fragilizadas e múltiplas, onde cada um só existe no e pelo olhar do outro; a heteronomia prevalece sobre a autonomia; ocorre uma compressão das categorias espaço-tempo (com predomínio do presente, do vivido); valorizam-se as histórias humanas e a imagem torna-se importante na constituição do sujeito e da sociedade, e a sua espetacularidade favorece um real reencantamento do mundo.

Por outra via, Morin tece uma crítica ao cientificismo e ao racionalismo afirmando que o pensamento simples, disjuntivo, lógico-dedutivo, já não é suficiente para compreender e explicar o mundo à nossa volta. Nesse sentido o autor considera que a rede de relações tecidas, tanto no mundo físico quanto no mundo social, leva-nos ao confronto com o desafio da complexidade, cuja qualidade de pensamento apresenta, simultaneamente, um pólo empírico e um pólo lógico e, desse modo, “pode-se dizer que há complexidade onde quer que se produza um emaranhamento de ações, de interações, de retroações.” (MORIN, I996, p. 274) 
Para Morin (1991), precisamos compreender o ser humano contemporâneo pela via da complexidade. Não é mais possível sustentar a noção insular do homem, separado da natureza e de sua própria natureza. Assim, esse autor sugere que "o homem não é somente biológico-cultural. É também espécie-indivíduo, sociedade-indivíduo; o ser humano é de natureza multidimensional." (MORIN, 1996, p. 28I) É importante compreender que, na perspectiva de Morin, abordar a noção de biológico significa compreender a noção de sujeito na lógica própria do ser vivo e não numa via única de análise da biologia como área de conhecimento.

O conceito de natureza abarca tanto nosso conjunto de heranças genéticas, como os aspectos que aprendemos por meio de nossas interações no ambiente social, de forma consciente e inconsciente. Assim, o biológico e o cultural são elementos inerentes ao conjunto de adaptações geneticamente estabelecidas. (DAMÁSIO, 1996) Essa visão do ser humano, segundo Morin, requer a busca de fundamentos numa lógica da complexidade em que a parte e o todo, a ordem e a desordem, o caos, a autoeco-organização, as ações e retroações, fazem parte da imprevisibilidade dos sistemas complexos.

Essas características da ambiência contemporânea apontadas por Edgar Morin têm aberto novas possibilidades de configurações para o corpo e a dança. Com efeito, percebemos, hoje, uma ênfase ao corpo que vai desde o seu "culto", através das academias de ginásticas e dos regimes da moda, até experimentações como o body modification e outras mais invasivas como as cirurgias plásticas e as de adequação de sexo. Além disso, surgem diversas linhas acadêmicas para o seu estudo, lançando novos olhares e modos de abordar o corpo.

Para a dança contemporânea, a quebra do unívoco e a busca pelo múltiplo abriram espaço para que se investigue novas configurações sobre o corpo que dança, que não estejam sustentadas pelos sistemas universalizantes do pensamento ocidental, como o pensamento cartesiano. $O$ corpo dançante hoje não é mais visto apenas em termos de sua relação cinética ou expressiva. Alguns coreógrafos procuram trabalhar/pesquisar o movimento, a sensação cinestésica, a fisicalidade, as ideias, a singularidade e as identidades daquele corpo específico que dança para que se possa reconhecer 
e incluir as diferenças, ressignificando, na dança, representações e metáforas construídas no/sobre o corpo.

Albright (1997) considera que a dança contemporânea, alicerçada nas teorias críticas culturais, pode ajudar a desvelar os vários significados tecidos entre as imagens do movimento, a experiência somática - corpo vivido/imaginado/percebido - e a identidade. Por essa ótica, o corpo dançante e as representações que o dançarino traz para a dança são resultados das redes tecidas em suas experiências com o ambiente, não sendo possível concebê-lo unicamente como um corpo natural, destituído de valores sociais e culturais, detentor, portanto, de uma identidade fixa.

Com efeito, a identidade do sujeito na contemporaneidade não se encontra centrada em si mesma, em seus aspectos biológicos, ou presa a um lugar social ou de representação, mas, abarca a possibilidade de transformar-se continuamente nas diversas interações, localizando-se num espaço do entre, tornando-se, assim, transitória. Morin (1996) afirma que a identidade abarca os princípios da diferença e equivalência, da exclusão e inclusão e da intercomunicação com o semelhante, que nos permitem subjetivamente sermos únicos e coletivos e termos uma personalidade múltipla no processo de construção do indivíduo-sujeito, o que coincide, parcialmente, com a perspectiva de Stuart Hall, quando este define o caráter oscilátório e multifacetado da identidade na contemporaneidade.

Abordando o mesmo tema, Rubidge (1998) coloca que o sujeito pós-moderno possui uma multiplicidade de identidades (seja em nível macro - coletivo, ou micro - pessoal) que estão em constante fluxo, mudando de acordo com a circunstância. Para a autora, num mundo onde a identidade tem caráter flutuante, a dança também se tornará potencialmente flutuante, uma vez que questões de identidade diretamente se relacionam com a sua produção.

Para Cunha e Silva (1999b), o corpo que dança tem uma "identidade movimentante" fundada na polissemia do material estético, isto é, o corpo, ao mover-se, "arrasta"| consigo o lugar, o transforma noutros lugares e, dessa forma, "o corpo que dança, nesse contexto, pode funcionar como um mediador de particular eficácia na construção de uma corpluralidade activa 
[...], [isto é], na perspectiva de uma assumpção identitária fundada na variabilidade". (CUNHA E SILVA, I999b, p. 23)

Essas relações estabelecidas em torno da ruptura com a representação e da pluralidade do corpo que dança, trazem a possibilidade de novas reorganizações para a dança, rompendo, principalmente, com fronteiras que até então definiam o corpo na dança apenas pelo viés técnico-performático e, nesse novo contexto, o conceito de técnica transforma-se e relativiza-se.

Na dança contemporânea, principalmente nas últimas décadas do século $X X$, o corpo do(a) dançarino(a) rompe as barreiras da "coisificação", de ser um(a) mero(a) executante e reprodutor(a) de movimentos criados por um(a) coreógrafo(a), tornando-se um(a) criador(a) e um(a) intérprete. Em geral, na atualidade, o próprio corpo do(a) dançarino(a) é considerado elemento essencial para o processo de criação.

Ao falar sobre as remarcações de fronteiras no corpo que dança, Greiner (1999a) enfatiza que um dos elementos fundamentais para essa mudança, na dança dos anos 1990, refere-se aos novos diálogos culturais que vêm sendo estabelecidos e envolvem a globalização, as redes midiáticas e as interfaces entre arte e ciência.

Greiner e Katz (2003, p. 13) salienta que é importante percebermos o corpo hoje como "sujeito de si mesmo e mídia do conhecimento" e esse viés nos permite apreendê-lo como uma estrutura complexa que necessita de novas bases epistemológicas para a leitura de seus processos de significação, de suas multiplicidades, que se encontram contidas no próprio corpo (corporificação) $)^{2}$.

Na perspectiva dessa autora, esses diálogos são importantes por estabelecerem de forma diferenciada o pensamento do corpo que dança, sendo que essa forma de pensar não pode ser compreendida por um viés reducionista, como uma tradução de temas e conceitos pertencentes ao campo cultural e social para a "linguagem" da dança. Como salienta Greiner (1999a, p. 7), "este diálogo entre as coisas que se modificam no mundo e o corpo que dança, ganha existência através da configuração de novas organizações, isto é, através da criação de novos modelos de pensamento." 
A busca por outras configurações de pensamento para a dança nos possíveis diálogos estabelecidos entre corpos de dançarinos com e sem deficiência, gera uma questão norteadora. Se a identidade e a dança na contemporaneidade tornam-se flutuantes, como estas podem ser relacionadas com o conceito de diferença no corpo dançante? Para estabelecer algumas reflexões sobre esse assunto toma-se como ponto de partida o conceito de diferença abordado por Gilles Deleuze.

\section{Diferenciando a diferença}

$\mathrm{Na}$ introdução do livro Diferença e repetição (1988), Deleuze enfatiza que a diferença e a repetição são assuntos pertinentes a vários campos, como a filosofia, a arte e o romance contemporâneo e, em torno desses dois termos, o autor percorre um longo caminho reflexivo.

A filosofia da imanência deleuziana se opõe às formulações transcendentais e, como enfatiza Bento Prado Jr. (1996), sua obra percorre a contracorrente do pensamento filosófico da segunda metade do século $X X$, deixando de lado todas as polêmicas em torno da pós-modernidade, voltando-se para a elucidação da nossa experiência no mundo contemporâneo, articulando filosofia, arte e ciência.

Essas articulações, para Deleuze, não são transposições de conceitos de uma área para a outra, mas sim a perspectiva de que o pensamento pode ser construído, tanto na arte como na ciência e na filosofia, como um pensamento nômade ${ }^{3}$, baseado na imanência, diferente daquele de artistas e filósofos que estruturam seu pensamento de uma forma fixa, presos a padrões já existentes, defensores de verdades absolutas e de representações clássicas que aniquilam a diferença.

Como expõe Regina Schöpke, Deleuze pode ser considerado como um pensador nômade, já que os nômades "são os verdadeiros habitantes das estepes, homens que transitam num 'espaço liso', ${ }^{4}$ pensadores da imanência que fazem do pensamento uma aventura de alto risco." (SCHÖPKE, 2004, p. 14) Por esse viés, o pensamento deve ser entendido como um 
processo, divergente, transgressor e descentrado, que pode resultar em novas conexões e interpretações.

Para Deleuze, apesar de a repetição ser comumente vista como generalidade, como elementos iguais que possuem o mesmo conceito, ela precisa ser compreendida em seu caráter transgressor e como singularidade, pois é necessário localizar o "se" da repetição, a singularidade naquilo que se repete. Para o autor, deve-se distinguir duas formas de repetição, sendo que,

Em todo caso, a repetição é a diferença sem conceito. Contudo, num caso, a diferença é posta somente como exterior ao conceito, diferença entre objetos representados sob o mesmo conceito, caindo na indiferença do espaço e do tempo. No outro caso, a diferença é anterior à Ideia; ela se desenrola como puro movimento criador de um espaço e de um tempo dinâmicos que correspondem à Ideia. A primeira repetição é repetição do mesmo e se explica pela identidade do conceito ou da representação; a segunda é a que compreende a diferença e compreende a si mesma na alteridade, na heterogeneidade de uma 'apresentação'. Uma é negativa por deficiência do conceito, a outra é afirmativa por excesso da Idéia. Uma é hipotética, a outra 'categórica'. Uma é estática, a outra é dinâmica. Uma é repetição no efeito, a outra na causa. Uma é em extensão, a outra é intensiva. Uma é ordinária, a outra é irrelevante e singular. Uma é horizontal, a outra é vertical. Uma é desenvolvida, explicada, a outra é envolvida devendo ser interpretada. Uma é revolutiva, a outra é evolutiva. Uma é de igualdade, de comensurabilidade, de simetria, a outra se funda no desigual, no incomensurável ou no dissimétrico. Uma é material, a outra é espiritual, mesmo na natureza e na terra. Uma é inanimada, a outra tem os segredos de nossos mortos e de nossas vidas, de nossos aprisionamentos e de nossas libertações, do demoníaco e do divino. Uma é repetição 'nua', a outra é repetição vestida, que forma a si própria vestindo-se, mascarando-se, disfarçando-se. Uma é de exatidão, a outra tem a autenticidade como critério. (DELEUZE, 1988, p. 55-56)

É interessante salientar que, para Deleuze, a repetição não está subordinada ao idêntico, o que ressalta a singularidade de cada repetição. Esse aspecto é muito importante para a compreensão da dança contemporânea, pois em muitas obras coreográficas a repetição do movimento é utilizada não como uma simples re-apresentação mecânica de uma célula 
de movimentos, mas como um elemento de pesquisa, gerador de uma estética singular.

O papel da repetição na dança é explorado por Ciane Fernandes (2000a) ao analisar o trabalho de Pina Bausch. Para a autora, a repetição é comumente utilizada na dança como treinamento, memorização de sequências ou como elemento formal da composição, resultando em formas de construção ou de confirmação de vocabulário. Apesar de Fernandes abordar especificamente o conceito da repetição na dança-teatro, concorda-se com a autora quando afirma que a dança-teatro - e podem ser incluídos aqui alguns trabalhos de dança contemporânea - explora a desconstrução de gestos e dos signos sociais pertinentes à singularidade de cada corpo e "eventualmente, as exaustivas repetições provocam sentimentos e experiências nos dançarinos e na platéia. Significados são transitórios, emergindo, dissolvendo e sofrendo mutações em meio a repetições." (FERNANDES, 2000a, p. 23)

Ampliando a perspectiva de Fernandes, considero que a repetição na dança contemporânea, ao explorar a complexidade do movimento, o transmutar do que se repete no corpo em seus diferentes estados, provoca deslocamentos, retroações, simulacros, pelos quais a diferença transita na organização que ocorre em cada repetição, transbordando séries heterogêneas de movimento que possuem sentidos e metáforas próprias, fazendo com que a repetição seja a diferença em si mesma.

Para Deleuze, a repetição é transgressão e cada repetição é singular e é afetada por uma ordem da diferença. Essa mesma relação se faz presente no que se refere à identidade, já que esta pode ser dissolvida, transformada e produzida pela diferença, já que "o Ser se diz num único sentido de tudo aquilo que ele se diz, mas aquilo de que ele se difere: ele se diz da própria diferença." (DELEUZE, 1988, p. 76)

Essas relações ocorrem também com o corpo dançante, quando a repetição é explorada como diferença na coreografia, fazendo com que cada retorno do movimento tenha o seu próprio significado.

É interessante ressaltar que Deleuze, apropriando-se do conceito do eterno retorno de Nietzsche, afirma que retornar é o ser do devir, pois “o eterno retorno não faz 'o mesmo' retornar, mas o retornar constitui o 
único Mesmo do que devem. Retornar é o devir-idêntico do próprio devir [...], [é] a identidade da diferença”. (DELEUZE, 1988, p. 83)

Esse conceito de repetição aponta para outra conexão com a abordagem proposta neste livro. Para Deleuze, a repetição se forma disfarçando, sem conceito prévio, e é este aspecto que a distingue, por exemplo, da estereotipia. O estereótipo é algo demarcado como igual e que se repete de forma "nua". Por essa via, normalmente quando se identifica a pessoa com deficiência, principalmente no que se refere à sua exterioridade, generaliza-se sua representação (identidade e semelhança), confundindo o conceito da diferença com algo que se inscreve simplesmente no campo conceitual, geral e abstrato. Assim, "enquanto se inscreve a diferença no conceito em geral, não se tem nenhuma Idéia singular da diferença, permanecendo-se apenas no elemento de uma diferença já mediatizada pela representação" (DELEUZE, 1988, p. 61) e que normalmente vem associada à negação e à contradição.

É importante salientar que existem distanciamentos entre a perspectiva de diferença de Deleuze e o conceito de estigma apresentado por Goffman (1988). Este autor define o estigma em referência a um atributo corporal profundamente depreciativo, como os próprios gregos já o faziam ao se referirem aos sinais corporais que poderiam representar o extraordinário ou o mau do status moral de quem o tinha. Nesse sentido,

Por definição, é claro, acreditamos que alguém com um estigma não seja completamente humano. Com base nisso, fazemos vários tipos de discriminações, através das quais efetivamente, e muitas vezes sem pensar, reduzimos suas chances de vida. (GOFFMAN, 1988, p. 15)

Ainda na perspectiva de Goffman, o estigma se instaura por meio de uma linguagem de relações e de atributos, que definem o que é normalidade e 0 que está fora dessa expectativa passa a ser o anormal, o monstruoso. Para Goffman, existem três tipos de estigmas: as abominações corporais, as culpas de caráter e as de cunho de raça, nação ou religião.

Por outra via, Deleuze enfatiza que a diferença não é apenas uma marca visível ou uma propriedade corporal; a diferença se instaura na relação, 
nos agenciamentos e, nesse sentido, a filosofia da diferença recusa a diferença delimitada como negação ou como negativo de limitação ou de oposição. Assim, a diferença não está circunscrita na exterioridade do sujeito.

Para Deleuze, o conceito de diferença não está preso aos princípios norteadores da representação (identidade, analogia, oposição e semelhança), ${ }^{5}$ devendo ser vista como ruptura, descontinuidade, como um elemento perturbador de uma ordem previamente estabelecida. Como já foi apresentado anteriormente, no sentido deleuziano, o "ser se diz na diferença” e, dessa forma,

[...] ele não é 'a' diferença em si, no sentido platônico do termo. Mas é diferença em si no sentido em que uma filosofia da diferença a toma: um ser unívoco que se diz na diferença. Nesse sentido, ele se expressa na multiplicidade e afirma as diferenças que o compõem, não como um todo fechado, nem mesmo como finito ou infinito, mas como um acabado ilimitado. (SCHÖPKE, 2004, p. I50)

Vale ressaltar que, para Deleuze, a univocidade não significa a existência de um único e mesmo ser; para esse pensador, os seres são múltiplos e diferentes, sempre produzidos por uma síntese disjuntiva, eles próprios disjuntos e divergentes. Esse jogo da diferença é ressaltado por Pealbart (2004, grifo nosso) ao afirmar que:

[Deleuze] fez da diferença um conceito eminente, [...] abrindo o caminho para a elaboração de uma ética da singularidade: não apenas colher as diferenças constituídas, sejam elas individuais ou coletivas, mas produzir novas diferenciações, fazer do homem um grande experimentador, um afirmador de modos de existência singulares.

É a existência de modos singulares de ser e, por consequência, a percepção de modos singulares de criação e produção do corpo que dança, que nos interessa quando se desloca esse conceito à arte/dança.

Ao abordar a questão da diferença no campo artístico, Deleuze enfatiza que o pensamento moderno nasce da falência da representação e da perda 
da identidade, fazendo com que a diferença e a repetição assumam o lugar do idêntico e do negativo, da identidade e da contradição, deixando-se de perceber a diferença como subordinada ao idêntico.

Para esse autor, no mundo moderno, no mundo dos simulacros, o jogo é o da diferença e da repetição e nessa relação, a divergência e o descentramento estão sempre associados à diferença e o deslocamento e o disfarce à repetição. Deleuze considera que a arte "nômade" libera os simulacros, tendo cada obra seu caráter singular e polissêmico, implicando que o simulacro seja o sistema em que emerge a própria diferença e o devir. Em suas palavras:

Por simulacro não devemos entender uma simples imitação, mas sobretudo o ato pelo qual a própria idéia de um modelo ou de uma posição privilegiada é contestada, revertida. O simulacro é a instância que compreende uma diferença em si, como duas séries divergentes (pelo menos) sobre as quais ele atua, toda semelhança tendo sido abolida, sem que se possa, por conseguinte indicar a existência de um original e de uma cópia. É nesta direção que é preciso procurar as condições, não mais da experiência possível, mas da experiência real (seleção, repetição etc.) [...]. Se é verdade que a representação tem a identidade como elemento e um semelhante como unidade de medida, a pura presença, tal como aparece no simulacro, tem o 'díspar' como unidade de medida, isto é, sempre uma diferença de diferença como elemento imediato. (DELEUZE, 1988, p. I24- I25, grifo nosso)

Nesse sentido, mostra-se a diferença diferindo, e ela só pode ser pensada em si mesma quando se desprende das amarras da representação. Com a experiência real a estética perde a bipolaridade de seus dois domínios a teoria do sensível e a teoria do belo - e nessa tessitura desterritorializada "o ser do sensível se revela na obra de arte ao mesmo tempo em que a obra de arte aparece como experimentação." (DELEUZE, 1988, p. 124-125, p. 123)

Por essa via, pode-se entender o pensamento como a afirmação da diferença e essa concepção possibilita uma direta articulação com o conceito proposto por Helena Katz (1994), a qual afirma a dança como pensamento do corpo. Por essa via, a dança torna visível ações que apresentam organizações 
das relações construídas na mediatização do corpo e ambiente, implicando em transformações que podem ser geradas no próprio corpo que dança.

O corpo é mídia de si mesmo, é corpomídia, ${ }^{6}$ pois, como assevera Katz (2006) "um corpo sempre mostra a si mesmo, o que equivale dizer que ele sempre se apresenta com a coleção de informações que o constituem naquele exato momento."

Essa autora ainda enfatiza que tratar o corpo como corpomídia traz conseqüências políticas e a maior delas centra-se na concepção de que o corpo não é e sim está, o que acarreta a instauração da "transitividade no lugar anteriormente ocupado pela noção de identidade”. (KATZ, 2006) A dança, sendo o pensamento do corpo, também pode estar afirmando as informações da diferença contidas na singularidade e nas ideias encarnadas no corpo que dança.

Nessa via, é pelo corpo que, num primeiro momento, a diferença é exposta e se dá ou não o reconhecimento, e é através desse reconhecimento que percebemos o limite entre o sujeito, o mundo e o outro, "lugar de onde se pode determinar a alteridade." (TUCHERMAN, 1999, p. 152) Para Tucherman, são esses lugares sociais que demarcam as fronteiras entre o que é idêntico (o mesmo) e o que é diferente (o outro). É assim que se criam pares opostos, como normal/anormal e eficiente/ deficiente.

Segundo o geneticista humano Karl Sperling (apud BALLET TANZ, 200 I), cada desvio resulta em determinada vantagem. Mutação e transformação não são somente processos naturais, eles são a própria base da vida, e todo desvio de uma "norma" é o que configura a própria "normalidade". Somente através da exceção, do irregular, pode a norma tornar-se visível.

Um outro aspecto a ser considerado como impulsionador pela busca da normalidade refere-se à forte presença do culto ao corpo na contemporaneidade, que empurra para o sujeito social a responsabilidade pela plasticidade do próprio corpo, no sentido de buscar a sua potencialização e manter a jovialidade.

Como observa Fontes (2004), a mídia reforça a busca pelo corpo canônico, ${ }^{7}$ cujas soluções altamente comerciáveis como clínicas estéticas, academias ou cirurgia plásticas, tornam-se cada vez mais anunciadas como 
a chance de salvação para quem não está atendendo aos padrões corporais que nos são impostos cotidianamente.

Por outro lado, o corpo que não é validado por essas expectativas, o qual a autora define como dissonante, ${ }^{8}$ como é o caso do corpo com deficiência, possui uma possibilidade ínfima de realizar uma meta-potencialização através de próteses que nunca lhe darão um sentido de "normalidade" e este, como uma dissonância, torna-se atrativo e consumível numa cultura de massa, podendo ser apresentado na forma de espetáculo ou denúncia, tornando-se uma mercadoria espetacular. (FONTES, 2004)

Cabe ressaltar que espetáculo aqui deve ser entendido na sua raiz etimológica do latim spectaculum, ou seja, algo que chama a atenção do olhar. Assim, alguns tipos de imagens têm servido como um grande chamariz, ou como bem ressaltam Sodré e Paiva (2002), para programas popularescos de televisão que assumem o papel de grande feira de variedades e sob a pulsão do olhar do espectador que fita a TV, independente do conteúdo ou dos significados imagéticos, mostram cenas grotescas que tiram a audiência de seu estado de paralisia. Nessa relação interdependente, essas imagens servem "como um recurso de socialização compensatória da massa excluída da inserção plena no espaço urbano.” (SODRÉ; PAIVA, 2002, p. I I4)

Por outro lado, ainda ao abordar o corpo dissonante, Fontes, citando Mae-Wo Ho (2004), afirma que, na sociedade contemporânea, com os avanços da biotecnologia, a desigualdade social pode se transformar em desigualdade genética, já que, na medicina preditiva, somente os ricos poderão pagar para melhorar seus descendentes e, nesse sentido, Mae-Wo Ho alerta para o perigo de um novo tipo de eugenia, que ampliará os preconceitos de nossa sociedade. Por esse prisma, a autora afirma que

Com o aperfeiçoamento genético de futuras gerações, [os deficientes] tendem a ser vistos como corpos absolutamente antagônicos aos corpos saudáveis que a ciência promete assegurar antes mesmo do nascimento. $E$ à medida que a ciência acena com a possibilidade de banir do corpo, em um futuro breve, a falha e a imperfeição - não pelo tratamento ou a cura do embrião não-saudável, mas pelo seu descarte ainda quando célula, pela sua exclusão e pela seleção de um 
outro, ainda celular, mas absolutamente sadio, virtualmente e potencialmente saudável - tem-se a possibilidade de um mundo onde a anomalia tende a ser cada vez mais rejeitada e estranhada. O fisicamente anômalo, o corpo biologicamente dissonante, será o monstro da corporeidade canônica e geneticamente higienista prometida pela ciência e passível de ser adquirida por aqueles que poderão pagar o seu preço, uma vez que tal possibilidade será colocada à venda, sob a forma de serviços médico-científicos pelas clínicas e hospitais de alta tecnologia. (MAE-WO HO apud FONTES, 2004, p. 62)

É importante lembrar que, apesar da autora aqui se referir ao dissonante como aqueles corpos com deficiência, para os quais a biotecnologia tem tentado garantir o seu descarte assegurando apenas o nascimento de corpos saudáveis em uma verdadeira busca pela "perfeição", o dissonante pode sempre ser um vir-a-ser, já que todo ser humano é suscetível de sofrer lesões que o tirem da condição de "normalidade" e o coloquem na condição de pessoa com deficiência.

Ao mesmo tempo, o vislumbrar da possibilidade da não aceitação da imperfeição nos remete ao paradoxo da própria finitude do(a) homem/muIher, já que, por mais perfeito que um corpo humano possa ser, sua decrepitude não tem como ser remediada.

Nesse sentido, como colocam Villaça e Goés (1998), a perfeição e a imperfeição estão em um paradoxal entrelaçamento, e o espaço criado entre esses dois pólos permite pensar o corpo em suas mutações, pois o imperfeito é a "busca do mais humano e o entendimento da perfeição como visão ingênua da onipotência que não percebe as ligações e ficções contidas no desejo da perfectibilidade." (VILLAÇA; GOÉS, 1998, p. 12-13)

Quando se pensa por esse viés sobre a dança, sabe-se que a expectativa do senso comum é encontrar dançarinos com físicos "perfeitos", pelo menos no que tange aos seus elementos compositivos - a visão iluminista das partes que compõem o todo - e na visão idealizada do corpo dançarino - um corpo com musculatura forte, magro e longilíneo. É desse modo que, pela visão, ao serem colocados em cena dançarinos com e sem deficiência, surge a primeira diferenciação na percepção da dança: o corpo do dançarino com deficiência não é o corpo aguardado como mídia dessa arte. 
O sentido de mídia empregado nesse modelo acaba equivocadamente colocando-o no sentido da palavra meio (do latim mediu), direcionando o corpo como instrumento de algo; assim, se de antemão o espectador apresenta um modelo fixo e pré-estabelecido de corpo que dança, haverá sempre um estranhamento, pelo menos inicial, no processo de fruição da obra.

Uma mudança de percepção só poderá ser configurada, após o contato e a efetivação nas interações estabelecidas, com a nova informação incorporada se, e apenas se, essa informação propiciar um outro entendimento de dança. Assim, considero que o tipo de informação, que é agenciada no momento do trânsito da obra coreográfica com o espectador, poderá implicar ou não na permanência da visão desse corpo como instrumento (como nos trabalhos que enfatizam a normalização do corpo com deficiência), ou então pode promover nesse corpomídia ressignificações a partir da inserção da diferença em si, do acabado ilimitado.

Apesar de correntes da dança contemporânea levantarem a bandeira da diversidade, da polissemia e indagarem o próprio corpo que cria e dança, ainda se percebe, no mundo da dança, muitas restrições quando o corpo que dança não se encaixa dentro de um padrão de expectativa da normalidade e se contrapõe aos cânones do esteticamente correto. Nessa ótica, ao abordarmos a inserção do corpo com deficiência na dança, entende-se que ele é percebido, muitas vezes, na sua incompletude, "anormalidade" e, assim, à margem, torna-se o outro não desejado, carregando o estigma da negatividade.

Essa visão negativa pode provocar reações, tanto no público em geral, como em professores e dançarinos, cujas respostas podem variar do riso à repulsa ou à comoção exacerbada. Certamente, esse corpo, com sua alteridade inquietante, é provocador de estranhamentos e a maioria das técnicas de dança nunca foi pensada para esse tipo de fisicalidade.

A presença de pessoas com deficiência na dança, seja na busca por uma atividade terapêutica, educativa, de entretenimento ou artística, tem proporcionado uma visibilidade de corpos normalmente ocultos. Com essa mudança, o cenário da dança, de uma forma geral, tem sido afetado pela presença - ainda que pequena - dessas fisicalidades e isso tem provocado 
algumas reflexões na área, ao mesmo tempo em que se abrem espaços até então herméticos para o sujeito com deficiência.

Por outro lado, isso suscita três outras discussões: a primeira refere-se aos conceitos de corpo e dança que vêm sendo aplicados em muitos trabalhos artísticos com pessoas com deficiência; a segunda se refere a quem vem atuando como professor de dança ou coreógrafo nesse âmbito; e, por fim, o próprio contorno para esse tipo de dança que, por meio da terminologia atualmente empregada, disabled dance ou o termo utilizado no Brasil, dança inclusiva, demonstra uma necessidade de demarcar um território cultural - que não deixa de ser político e social - , mas, que pode implicar em outras representações estagnadas.

Mesmo com as mudanças significativas que vêm ocorrendo na sociedade contemporânea, padrões hegemônicos não permitem que se perceba que a emersão da imagem das pessoas com deficiência na sociedade e na cultura - seja pela mídia ou pela entrada em outros territórios até então demarcados pelos corpos idealizados, como é o caso da dança - tem propiciado, a duras penas, conquistas dos direitos das pessoas com deficiência como cidadãos.

Ao mesmo tempo, inicia-se uma dialogia com a diferença, baseada na alteridade, não mais presa a representações ou a única leitura dos pares dicotômicos, mas criando maleabilidades para o cruzamento de fronteiras até então demarcadas por espaços estáveis, o que contribui para que os terrenos sociais e culturais, inclusive os da dança, tornem-se mais movediços.

\section{NOTAS}

I $O$ arrastar é aqui utilizado no sentido de enfatizar o movimento de reapropriação.

2 Tradução de embodied. Greiner (2005, p. 34) aponta que a tradução desse termo para o português pode provocar equivocadas interpretações tais como "baixar um espírito num corpo". Incorporação deve ser entendido como organização de estados do corpo.

3 Característica atribuída por Deleuze ao pensamento de Nietzsche por basear-se, dentre outras características, no fluxo, no devir. 
4 O espaço liso é apresentado por Schöpke (2004) como contraposição ao espaço estriado, o qual se refere aos pensamentos sedentários daqueles que defendem a transcendência, a metafísica.

5 Deleuze (1988) identifica quatro aspectos da representação: identidade (conceito indeterminado); analogia (conceitos determináveis), oposição (determinações no interior do conceito); e semelhança (determinação do próprio conceito).

6 Termo cunhado por Greiner e Katz (200I), que nega o corpo como instrumento de alguma coisa e define-o como mídia de si mesmo, cujas informações e cruzamentos culturais estão contidos no próprio corpo em suas negociações com o ambiente.

7 Conceito utilizado por Fontes em sua tese (2004) para definir os corpos que atendem às normas.

8 Fontes (2004) os define como os corpos que não conseguem atingir os padrões corporais determinados, principalmente, pela mídia. 


\section{DAS GRUTAS, DOS GUETOS, ÀS SUPERFÍCIES DISSIMULADAS}

Estudiosos da história da arte e da estética predominantemente exemplificam os movimentos artísticos e estéticos a partir das artes visuais. Referências à dança normalmente são encontradas apenas nos livros de história dessa área, que tendem a apresentar uma visão cronológica, generalista e tradicional de sua abordagem, quando não há distorções imaginativas, distanciando-se das propostas da historiografia contemporânea.

Entendemos a dança como uma linguagem que estabelece interações recíprocas com o contexto e essa perspectiva possibilita também desmistificar a dança como uma arte com linguagem universal, na qual o corpo é visto como uma garantia dessa troca cultural, sendo equivocadamente considerado como o grau zero da cultura e os movimentos do corpo, considerados o grau zero da comunicação. (LEPECKI, 1998)

Nesse sentido, pensar a historiografia da dança a partir de recortes temáticos favorece o estabelecimento de conexões, com aspectos nem sempre tão discutidos na dança. Opta-se aqui em colocar um foco no corpo, 
buscando encontrar pistas da presença de corpos não-idealizados pela estética clássica, discutindo a categoria estética do grotesco, sem ter a pretensão de estabelecer uma conexão ampla com toda a história da dança, mas com a intenção de apresentar algumas topografias que, nessa relação, estão presentes.

Ao relacionar o conceito de grotesco com o corpo humano, depara-se com a existência de padrões de normalidade que visam a distanciar corpos que se encontram fora de padrões esperados e representam o exagero, o desvio e a anormalidade. É importante salientar que um desvio não existe isoladamente, mas está diretamente relacionado a um determinado contexto e, no caso do corpo que dança, ora em questão, os desvios são considerados a antítese do corpo idealizado para a dança.

Greiner (2005), ao analisar as relações entre corpo e cultura, menciona que devemos entender esses dois sistemas como mutuamente contaminados e, por esse prisma, o corpo que dança não se constitui/transforma distanciado do contexto onde está inserido, mas, nesse processo de intercâmbio de informações entre corpo-cultura, o corpomídia torna-se “criador de cadeias sígnicas” cujos sentidos estão no movimento. Por esse prisma, criam-se possíveis articulações entre o corpo que dança e a categoria estética do grotesco.

Para Sodré e Paiva (2002), o grotesco é na maioria das vezes o resultado de um conflito entre cultura e corporalidade, e pode assumir diferentes modalidades expressivas, como a teratológica, a escatológica ou a crítica. Dentre essas categorias, a que mais interessa neste texto refere-se à apresentação crítica do grotesco, pois, como apontam esses autores, ela "dá margem a um discernimento formativo do objeto visado, ou seja, não propicia apenas uma privada percepção sensorial do fenômeno, mas, principalmente, o desvelamento público e reeducativo do que nele se tenta ocultar." (SODRÉ; PAIVA, 2002, p. 69)

Nesse sentido, o corpo grotesco passa a ir além de um objeto de contemplação e é entendido como uma forma especial de reflexão sobre a vida e, dessa forma, articula a expressão criadora e a existencial. Ao definirem a categoria estética como um sistema de elementos que fazem com que uma 
obra alcance determinado gênero, Sodré e Paiva (2002) consideram que três planos se articulam para determiná-la: a criação da obra, seus componentes e os efeitos de gosto que ela provoca junto ao contemplador.

Por outra via, Vásquez (1999) destaca que as categorias estéticas são determinações gerais que permitem apreender as similitudes e as afinidades existentes entre categorias estéticas particulares. Esse autor alerta que, por mais de vinte séculos, o belo foi visto como uma categoria central e que uma alteração significativa só aconteceu em meados do século XIX, quando mudanças radicais da arte abriram espaço para que a arte ocidental, liberada do belo clássico, configurasse novas categorias que abrangessem, dentre outras, o sinistro, o feio e o grotesco, não devendo ser estas consideradas como pólos negativos. Para esse autor, o feio também ocorre na esfera do sensível, e ao estabelecer identificações diretas entre bom/belo, mau/feio, isso é feito com a intenção de ignorar a própria natureza, estética e moral dos termos contrapostos.

O feio, nesse sentido, não se delimita como um polo negativo do belo e nem pode ser considerado como o resultado da retirada de elementos positivos que constituem o belo; o feio, para Vásquez, possui uma qualidade estética positiva. É assim que o grotesco pode se configurar como um tipo de criação artística, com a presença ativa de algo estranho, fantástico, irreal ou antinatural, cujos resultados podem provocar reações diversas, como estranhamentos, atração, risos ou repulsa. Na concepção de Kayser (2003), o grotesco tem componentes do fantástico ou do sobrenatural, apresentando um mundo alheado, cuja ordem se desarticula, e o que era familiar torna-se estranho e sinistro.

Vários autores, como Sodré e Paiva (2002), afirmam que, apesar do grotesco estar associado ao disforme (conexões imperfeitas) e ao onírico (conexões irreais), esse termo vem sofrendo, ao longo do tempo, transformações metafóricas em seu sentido. $O$ termo grotesco aparece pela primeira vez no século XV, em decorrência de um tipo de pintura ornamental descoberta, na Itália, em escavações de grutas (grotto) datadas do período romano.

Esse tipo de representação mistura elementos da forma humana com animais e vegetais, criando uma arte ornamental que, com características 
estranhas, sobrenaturais e híbridas, destoa do realismo pictórico - com formas simétricas e clássicas - vigente no período de sua descoberta.

Inicialmente aceito como um modismo ornamental, o grotesco passou a ser rejeitado pelos críticos da arte classicista, principalmente ao se depararem com o tratado estético do arquiteto romano Vitrúvio, que classificava esse tipo de representação como bárbara, monstruosa e artificial. Para Sodré e Paiva (2002, p. 29-30), “a divulgação da diatribe de Vitrúvio, por Vasari, no século XVI, transforma o admirável em aberrante. Era a própria autoridade da tradição clássica que rejeitava os fantasiosos jogos figurativos, destinando-os ao reino das sombras."

Apesar de ter o seu valor estético negado na própria Antiguidade podemos encontrar vestígios do grotesco nos mitos e nas representações artísticas, relacionados a pares duais como racional/irracional e animal/humano, presentes nas figuras mitológicas, como a Medusa, que mistura elementos humanos com animais e vegetais.

Tucherman (1999) explana que certas figuras mitológicas, como o minotauro, o centauro e outros monstros imaginários trazem à tona suas origens, a partir de hibridizações de espécies de diferentes naturezas (animal/ humana ou divina/humana) e sua descrição não é feita pela falta, mas pela mistura dos elementos.

Assim sendo, o monstro interroga a humanidade do "outro" e, dessa forma, ele não pode ser visto como uma simples oposição ao humano, mas como um sistema complexo de relações de aproximação e distanciamento, de misturas e de hibridização. Nas palavras da autora, "os monstros talvez existam para nos mostrar o que poderíamos ser, não o que somos, mas também não o que nunca seríamos e assim articulam a questão: até que grau de deformação (ou estranheza) permanecemos humanos?.” (TUCHERMAN, 1999, p. 101, grifo nosso)

Ao discutir parcialmente essa questão, a autora afirma que o monstro pensado/simbolizado como uma aberração apresenta a necessidade de uma normalidade humana, de um corpo lógico. Destarte, na cultura grega, a identidade humana é construída a partir do confronto do(a) homem/muIher com os deuses e os animais, pois, os deuses são híbridos, imortais 
e a fugacidade humana diferencia-se da natureza animal pela cultura, de forma oposta ao descontrole (hybris), violência e desregramento. (VILLAÇA; GÓES, 1998)

A expectativa de normalidade pode, por exemplo, ser percebida na Grécia dentro do paradigma espartano. Como uma comunidade guerreira, Esparta dedicava-se ao disciplinamento do corpo, em que a perfeição, beleza e força eram objetivos a serem alcançados. Desse modo, praticava-se uma eugenia radical, eliminando-se crianças que nasciam com defeitos.

Ao abordar o corpo na Grécia antiga é necessário salientar que a prevalência de uma estética clássica, em que o corpo era representado em sua perfeita harmonia e proporção, também interferiu na concepção e funções da dança naquele período histórico.

A imagem do corpo grego, ligado a princípios de uma "estética da existência" (TUCHERMAN, 1999), não era a de um corpo natural, e sim de um corpo produzido em seu constante aprimoramento, e isso pode ser percebido no desnudamento dos corpos dos jovens nos jogos públicos, já que o corpo idealizado era pensado no e para o universo masculino, como também nas representações nas artes, na educação e no cotidiano do cidadão grego.

Por outra via, é interessante assinalar que Platão, além de abrir uma ruptura entre corpo e mente, classifica as danças gregas em danças de beleza e de feiúra (BOURCIER, 1987), separando as danças apolíneas (relacionadas à ordem), das dionisíacas (relacionadas ao êxtase).

Como um rito que promove uma inversão de uma ordem instaurada, - culto a Dionísio aproxima-se da categoria estética do grotesco. Nesse culto, as mênades - mulheres possuídas pela loucura sagrada - dançavam freneticamente no alto das montanhas, local consentido para a realização desses rituais e praticavam a omofagia; aqui o grotesco representa o rompimento de fronteiras entre racional e irracional, sagrado e profano, humano e animal. Portinari (1989) aponta que os excessos desses rituais dionisíacos foram criticados no período clássico, tendo sido disciplinadas essas manifestações até transformarem-se em liturgias.

Numa leitura feminista, Hutcheon e Hutcheon (2003) salientam que, na cultura ocidental, a repressão à presença da mulher em rituais sagra- 
dos ocorre pela suspeita simbolicamente depositada sobre elas, sendo o corpo das mulheres dançarinas relacionado ao irracional, conectado ao dionisíaco, ao excesso e à transgressão, em oposição ao apolíneo, que representa o racional, o controle físico, a disciplina e é relacionado com o universo masculino.

Outra acepção do termo grotesco que pode ser vinculado à dança refere-se ao conceito apresentado por Bakthin, em 1965, ao analisar, na obra de Rabelais, a presença da cultura cômica popular, identificando o rebaixamento representado pela oposição entre o alto e o baixo ventre. Para Bakhtin (1993, p. 26),

O corpo grotesco é um corpo em movimento. Ele jamais está pronto nem acabado: está sempre em estado de construção, de criação, e ele mesmo constrói outro corpo; além disso, esse corpo absorve o mundo e é absorvido por ele.

Nesse sentido, o corpo grotesco - um corpo aberto e suscetível às metamorfoses - é diferente do corpo clássico, que é um corpo fechado, definido e acabado. Ao trazer essa concepção para o grotesco, Bakhtin amplia a definição apresentada em 1957 por Kayser, baseada principalmente na análise de obras literárias, e inclui as manifestações populares, mostrando que o grotesco, como já tinha sido explanado, é um conflito entre cultura e corporalidade.

Na Idade Média, o rompimento de hierarquias se faz presente nas festividades populares, principalmente a carnavalesca, apesar de toda a influência cristã que, numa perspectiva dualista, separava corpo e alma e condenava as manifestações ligadas ao estado físico do corpo, como aquelas em que o animal e o humano se uniam. (BROWN, 1990)

Para Lipovetsky ( 1989), na cultura medieval, o cômico é unificado pela categoria do realismo grotesco, o qual rebaixa o sublime, o poder, o sagrado, por meio de imagens hipertrofiadas da vida material e corporal. É importante salientar que, como afirma Lipovetsky (1989, p. I29), “[...] todo o cómico medieval oscila assim no sentido de uma imaginária grotesca que, antes de tudo, devemos não confundir com a paródia moderna, de 
algum modo dessocializada, formal ou 'estetizada'." Esse autor ainda alerta que o cômico medieval é ambivalente e o simbolismo do rebaixamento está diretamente ligado à inversão entre alto e baixo como, por exemplo, na relação entre morte e ressurreição.

É por essa via que as manifestações populares carnavalescas se abrem para uma mistura de corpos em que, por exemplo, anões e pessoas com deficiência se misturam à população, mas não no sentido de uma inclusão social, e sim de uma permissividade de convívio espacial, através do rompimento temporário de fronteiras e por serem alvos de escárnio já que, como já foi citado antes, o realismo grotesco baseado no rebaixamento do sublime, do sagrado, coloca o corpo como principal acontecimento dessa manifestação.

Nesse sentido, Kuppers (2003), ao analisar a teoria bakhtiniana e suas relações com a performance contemporânea, destaca que, apesar do carnaval evocar conceitos como unidade e comunidade, nessa manifestação não há uma distinção entre plateia e palco, o que viabiliza a presença de corpos extraordinários (do deficiente ou do freak), já que não são o único foco para a comunidade.

Essa autora ainda salienta que o corpo grupal carnavalesco difere da imagem grotesca, já que esta é uma imagem de oposição que admite um papel secundário dentro da dominância e, consequentemente, ao ser colocado na cena, favorece a emersão do que está à margem da norma.

Em outra análise crítica, Russo (2000) observa que a apreciação de Bakhtin, apesar de apresentar uma crítica à modernidade e seus efeitos, baseou-se no carnaval dos primórdios da Europa moderna e, nesse contexto, o grotesco configurado pelo teórico russo apresenta características da transformação material e social, vinculado a todos os âmbitos culturais, apresentando, assim, uma análise nostálgica de um carnaval perdido que ficou trancado na alcova do privatismo burguês. Para a autora, essa forma de percepção tem deslocado as questões de exposição e contenção do corpo para a área do social, fundado como um campo simbólico, deixando o discurso do carnaval destituído de uma análise crítica de temas como gênero e política. 
Retomemos a questão da imaginária grotesca medieval e sua conexão com a dança. Essa aparece nas danças macabras, realizadas geralmente nos pátios externos das igrejas, isto é, nos cemitérios, nos quais as pessoas dançavam freneticamente buscando expurgar as doenças, a morte, ou alcançando-a através da exaustão e do êxtase. Logicamente, essa dança está relacionada ao contexto social, em que a peste, o envenenamento por picadas de aracnídeos e outras doenças erradicaram grande parte da população na Idade Média.

A lgreja, na tentativa de desarraigar as manifestações escatológicas e exercer um controle disciplinar sobre o corpo, enfatiza a dualidade corpo e alma, e passa a incorporar, numa relação dúbia de tolerância e reprovação em seu teatro religioso, a dança macabra, associando-a a uma visão teocêntrica, na qual os homens estão submetidos aos desígnios de Deus.

Assim, essa dança, transformada em representação, passou a simbolizar "a insanidade causada pelo pecado" (PORTINARI, 1989), associado aos estados do corpo. Tal dança, entretanto, com o passar do tempo foi desaparecendo, dando lugar a movimentos mais distanciados dos valores carnais e do transe.

A partir do paradigma renascentista, com a idealização e o desvelamento do corpo humano e a demarcação de fronteiras entre as diferenças (indivíduo/coletivo; eu/outro), não há espaço para o desarmônico ou disforme. É nessa perspectiva que, nos primórdios do balé, cria-se uma distinção entre a dança da corte e a do povo, baseada nas formas culturais burguesas e, com o desenvolvimento dessa arte, estabelecem-se definições sobre o perfil do corpo que dança, delimitado pelo aprimoramento técnico e pelo ideal clássico. Afinal, no pensamento moderno, descarta-se o aspecto natural do corpo e ele passa a ser ligado à razão e à cultura.

A ênfase na racionalização do corpo, principalmente com a revolução iluminista, que, com Descartes, compara o corpo a uma máquina composta de partes que se articulam para o funcionamento do todo, traz para o centro das artes uma preocupação sobre a perfeição. É interessante notar que, como assinala Coli (2002), a preocupação/fascínio iluminista por um corpo que se desmembra - o que o autor define como poética do fragmento enfatiza, contrariamente, uma preocupação com a completude humana. 
Coli (2002) apresenta como exemplo dessa inquietação uma prática constante nos ateliês de restauração, desde o Renascimento até o final do século XVIII: a reconstituição, por meio de próteses, das partes ausentes de estátuas descobertas em escavações arqueológicas, dando a elas um sentido de plenitude para o público que as aprecia, mas, por outro lado, na busca pela harmonia, o restaurador junta pedaços desconexos de outras estátuas.

Considero que, do mesmo modo como o Frankstein, que é construído por pedaços de cadáveres, essas estátuas, ao buscarem o corpo ideal, passam a indagar a própria ciência e a arte. As reconstituições de estátuas, bem como a ênfase na representação do corpo perfeito na dança, reforçam a idealização do corpo que, abarcado pelo modelo da normalidade, não abre espaço para a visibilidade da falta e da diferença.

A objetivação sobre o que é a expectativa de uma norma - seja na dança ou na sociedade como um todo - cria o que Foucault chama da microfísica do poder. $O$ desenvolvimento científico, principalmente entre os séculos XVI e XVIII, favorece a criação de mecanismos de disciplinamento corporal, com o uso de objetos técnicos para se atingir tal finalidade, e criam-se espaços sociais fechados, destinados ao disciplinamento e à vigilância, formando uma sociedade disciplinar marcada pela observação.

A partir do século XVI - apesar da diferença e do diferente serem escamoteados do meio social por meio do confinamento em espaços como sanatórios, escolas especiais e prisões - é comum acontecer, em espaços públicos como as feiras, exibições do que é considerado exótico ou anormal: índios, gigantes, ventríloquos e pessoas com defeitos congênitos são os atrativos de um grotesco teratológico oferecido para uma multidão curiosa pelo que está fora das normas estabelecidas.

Não obstante as mudanças conceituais ocorridas até o século $X V I I I$, o grotesco só passa a ser analisado como uma categoria estética na arte nesse período, tendo como um dos marcos a publicação de Justus Moser (Arlequim ou a defesa do grotesco cômico), influenciado pela Commedia dell'arte com a figura caricatural do Arlequim.

Outro marco referencial é o prefácio (Do grotesco ao sublime) da obra Cromwel (1827), de Victor Hugo, que defende a entrada do grotesco como 
categoria estética. Neste texto, o autor, circunscrito no contexto da estética romântica, aponta que é exatamente no período moderno que o grotesco surge como um novo tipo de poesia, cuja forma é a comédia.

Para Hugo é esse aspecto que faz com que compreendamos a separação da arte antiga e da moderna, da literatura romântica da literatura clássica, o que vai implicar em uma ambiguidade do grotesco e do sublime, o coabitar do feio e do belo. Nesse sentido, "[...] na nova poesia, enquanto o sublime representará a alma tal qual ela é, purificada pela moral cristã, ele, [o grotesco], representará o papel da besta humana”. (HUGO, 1988, p. 33)

Por essa via, percebe-se que o grotesco para Victor Hugo está imbuído dos preceitos cristãos e, como afirmam Sodré e Paiva (2002), ele abandona a versão renascentista do grotesco, colocando de lado sua origem pagã, e amplia drasticamente o rol das representações do grotesco na arte, principalmente na literatura.

Hugo (1988) ressalta que, de uma forma tímida, a comédia já estava presente na tragédia (Helena; Orestes), bem como nos personagens grotescos (sátiros; cíclopes). No pensamento moderno, o grotesco traz o sentido da incompletude e tem um papel imenso: de um lado cria o disforme, o horrível; do outro, o cômico e o bufo.

Como representantes da poesia moderna que receberam influência do grotesco, Victor Hugo cita autores como Cervantes, Ariosto e Rabelais, sendo que, para ele, Shakespeare é o exemplo da fusão do grotesco e do sublime no drama. Para esse autor, a poesia descritiva está morta e a boa poesia seria a pitoresca. Nesse sentido, deve estar presente no drama a "cor local" (o característico, influência do romantismo) e o poeta deve ter a correção da língua, mas, ao mesmo tempo, ousar em mudanças.

Podemos perceber a presença dessa "cor local" na dança através do balé La fille mal gardée, um balé-pantomina de Jean Dauberval, criado em I789, baseado nas concepções de Noverre, mas, cujo sucesso só foi obtido no ano de 1827, passando a fazer parte do repertório da Ópera de Paris.

Esse balé, com características do cômico, narra o romance de Lisa, fiIha de uma rica proprietária que pretende casá-la com Alain, filho do rico Thomas; Lisa, porém, apaixona-se por Colas, um simples camponês, e ten- 
ta de todo modo evitar o noivado com o pretendente eleito por sua mãe. A trama em si mostra a preocupação da época com uma quebra de fronteiras entre a burguesia e o povo, já imbuído pelo espírito da fraternidade, liberdade e igualdade, mas, como afirma Bourcier (1987, p. 200),

Se a revolução romântica podia gozar destes novos direitos no campo da literatura e das artes plásticas, porque elas atingiam o grande público, o mesmo não acontecia com a dança. A Ópera [de Paris] detinha o monopólio do balé [...] e, administrativamente, era parte da casa do rei [...] concedido a um administrador [...] [e] devia, portanto, procurar sucesso junto ao público, sendo que este continuava a ser recrutado na classe rica, conservadora, que não exigia subversão nem na arte nem na sociedade; um público estático numa sociedade em movimento.

Com essa perspectiva, enfatiza-se duas questões intrínsecas em La fille mal gardée. A primeira refere-se à concepção de corpo ainda presente nessa coreografia. Apesar da inclusão de danças e músicas populares, a estética que norteia o espetáculo é a do balé, que, com a restrição de seus passos codificados, tenta uma aproximação com o pitoresco, mas não consegue desvencilhar-se de suas convenções, pois essa arte, concebida como erudita, busca a todo custo mostrar a nítida distinção entre a "alta" e a "baixa" classe, entre o "erudito" e o "popular" e, desse modo, estiliza as danças populares, dando a elas uma "aura" artística. Contrariamente à posição assumida por Portinari ( 1989), consideramos que a coreografia imprime um postiço maneirismo aristocrático, sem conseguir romper com o paradigma de uma fidalguia em decadência.

O segundo aspecto refere-se à concepção do personagem Alain, apresentado como um sujeito rico, porém bobo e infantil. A construção desse bailarino-personagem passa a ser circunscrita pelo seu figurino, pela ação dramática e pelos movimentos: com cabelos desarrumados, largas roupas e movimentos descoordenados. Alain torna-se o "bobo da corte", aproximando-se do personagem bufão e cômico caracterizado por Victor Hugo como um dos tipos da estética grotesca, só que numa perspectiva estere- 
otipada do grotesco, o que imprime ao personagem uma ação de chacota à burguesia vigente, ao mesmo tempo em que apresenta a ambiguidade do grotesco e do sublime. Do mesmo modo é interessante assinalar que o papel de madame Simone, a mãe de Lisa, normalmente é interpretado por homens, exacerbando seu aspecto rude.

Apesar de esse balé estar de acordo com o contexto do século XVIII, a presença da estética romântica, na dança, ocorre mais tarde do que nas outras artes e as obras coreográficas, influenciadas pelas literaturas germânica e inglesa, passam a ter um libreto escrito por um dramaturgo, cujas narrativas apresentam arquétipos da heroína romântica e vêm recheadas de sílfides, de almas fantasmas, de títeres, que mostram a existência de dois mundos: o material e o imaterial.

A chegada da iluminação a gás e do maquinário - que dá movimento aos cenários e aos próprios bailarinos - propicia a criação de um clima de ilusão, e com a contribuição da sapatilha de ponta como um novo artifício do balé, fica visível a busca pelo distanciamento do terreno. Na estrutura desses balés românticos, normalmente, os aspectos da realidade são apresentados no primeiro ato e a preocupação com o espírito e o campo do irreal ficam direcionados ao segundo ato, o que evidencia esta dicotomia em sua ação estrutural.

Ann Daly (1997) ao analisar os discursos presentes no ballet clássico, analisa que em um escrito de Theóphile Gautier a dança é definida como uma arte de mostrar belas formas em posições graciosas, cujo desenvolvimento se torna agradável de ser visto. Nesse mesmo texto Gautier reafirma uma nítida diferença e limites entre o papel masculino e o feminino na dança, tanto no que se refere à qualidade dos movimentos, quanto à ação dramática. Essas notas de Gautier reforçam algumas análises sobre os balés produzidos no século XVIII e no início do século XIX, nos quais se constata a presença de regras sociais patriarcais, em que os movimentos mais fortes são realizados pelos homens, devendo sustentar a imagem viril.

Sua ação dramática é conectada à realidade, tornando-se assim um suporte, tanto corporal, como de conexão com o contexto para sua partner. As bailarinas, com sua ambígua caracterização - frágil/heroína, etérea/ero- 
tizada, bela/pálida, com a ocultação do esforço físico e com os pés deformados pelo uso das pontas, tornam-se "divas" intangíveis, distanciadas da realidade e objeto do desejo masculino.

Como analisa Foster (1996, p. 3, tradução nossa),

[...] ela, [a bailarina], existe como uma demonstração do que é desejado, mas, não é real. Seu corpo flama-se com a carga de desejos de tantos olhos, ainda que a chama não tenha substância. Ela é, em uma palavra, o falo, e ele, [o bailarino], personifica a força que a persegue, guia e manipula.

corpo construído nos balés românticos também teve influências das informações presentes no século XVIII "com as primeiras formulações estratégicas sobre o ensino do movimento através da razão." (GREINER, 2005, p. 52) Esse balé centra-se cada vez mais na exposição das linhas e habilidades técnicas da bailarina, aliada a uma dose interpretativa, trazendo um paradoxo para o corpo dançante: um corpo que valoriza as mais perfeitas formas tenta incorporar os temas circunscritos pelos libretos, apresentando estórias de um mundo irreal, alheado, reconstruindo assim o espaço e o mundo.

É necessário perceber que essa dança só se concretiza por meio da sua organização sistêmica, com seus elementos cênicos, como figurinos, iluminação e maquiagem, que criam essa atmosfera, e com o auxílio da pantomima que, por meio de gestos simbólicos, esclarece para o público do que se trata a ação, pois apenas os movimentos pré-concebidos do balé são insuficientes para elucidar a narrativa. No balé romântico e no início do neoclassicismo, pode-se perceber uma cisão entre a forma e conteúdo, no sentido de que o corpo transcende a materialidade e, assim, o sobrenatural, o mundo alheado, fica diluído na atmosfera da narrativa coreográfica.

A partir do romantismo, o grotesco assume uma intencionalidade marcante, tornando-se desvelado e aliado a alguns dos preceitos da modernidade, como o fragmento, que irá enfatizar a suspensão das ordenações da realidade, bem como a diversidade humana presente em nossa sociedade, mas de uma forma peculiar. De uma forma geral, até o século XVIII, 
nas produções das artes visuais, o feio, o disforme, só ocorre quando bem representado (VASQUEZ, 1999) e retratado dentro de uma perspectiva de normalidade, como pode ser percebido na extraordinária plasticidade dos corpos de Bosch, no higienizado quadro de Poussin - onde São Erasmo é destripado sem mostrar as vísceras ou uma gota de sangue - ou nos limpos e arrumados mendigos e aleijados presentes nos quadros de Peter Brueghel.

É imprescindível lembrar que é nesse mesmo século XVIII que a medicina passa a realizar uma classificação para os sujeitos, apresentando as características do funcionamento de um corpo normal. Consequentemente, os corpos que não atendem a essas normas e apresentam incompletudes ou desvios são taxados como um todo deficiente e, por isso, como seres estigmatizados, devem ficar à margem da sociedade.

Quanto à dança, a presença desses corpos, nas poucas vezes em que são aludidos, ficou restrita a representações feitas por corpos "normais" às estereotipias dos corpos não idealizados, já que no palco só havia possibilidade da manifestação de uma única perspectiva de corpo.

Os outros corpos só encontraram espaço nos shows periféricos ou marginais, que permitiram não a apresentação de uma obra artística, mas promoveram a "exposição" das anomalias corporais, dos freaks. Nesses espaços, onde um público ávido pelo exótico pagava um ingresso para consumar seu voyerismo, o olhar do "normal" reconhece e contempla a não normalidade e há aqui uma paradoxal atração e repulsa pela deformação e desvios.

No século XIX, mesmo sendo um período regido pela moral vitoriana, os freak shows ampliaram sua atuação, principalmente na Inglaterra e nos Estados Unidos, tendo em seu elenco atrações como a mulher barbada, a gorda, o engolidor de fogo e as pessoas com deficiências ou anomalias, como siameses e anões. Analogicamente, como já foi citado no capítulo anterior, esse mesmo tipo de exposição pode ser visto atualmente, no século XXI, nos freak shows televisivos que exploram de forma depreciativa e, muitas vezes humilhante, a deficiência.

Curiosamente, voltando ao século XIX, esta foi também uma época de desenvolvimento de uma cultura física (body building), enfaticamente localizada 
em torno do corpo masculino, em que o nu de um corpo musculoso era considerado aceitável para os padrões morais da época. Para Thomson ( 1997 apud KUPPERS, 2003, p. 34, tradução nossa),

Numa era de transformação social e reorganização econômica, os freak shows do século XIX foram um ritual cultural que dramatizou a hierarquia social e a fisicalidade dessa era, através do foco no estigma corporal, o qual pode ser coreografado como um contraste absoluto com a corporeidade americana, reconhecida como a normal e a verdadeira.

Além dos freak shows, os espaços de audiência médica, onde eram apresentados casos de desvios, principalmente aqueles relacionados ao corpo feminino, como a histeria, ou então estudos sobre as deficiências congênitas e das práticas de dissecação, serviram também para sustentar o viés da normalidade. Pela via do discurso médico, assim, se "institucionaliza" a anormalidade por meio da criação de espaços de reclusão, como os sanatórios e as clínicas, para os portadores de doenças e deficiências.

Se durante o século XIX, mesmo com todas as mudanças ocorridas no cenário social, político e econômico, a dança ainda ficou presa aos resquícios do romantismo ou ao academicismo, podemos notar mudanças na entrada do século $X X$. Contrapondo à forma como é abarcada a estética grotesca no romantismo, pode-se perceber um outro modo de sua manifestação na obra L'après-midi d'un faune, coreografado por Vaslasv Nijinsky, em 1912.

Essa coreografia rompe com os paradigmas românticos, invertendo as relações dos papéis masculinos e femininos no balé e traz à tona a presença da homossexualidade na dança; apresenta um corpo semi nu em cena, com uma inovadora pesquisa e novas qualidades de movimentos para o balé, com uma clara contaminação dos princípios dalcrozianos e do pensamento da dança moderna.

Além disso, os movimentos sexualizados de Nijinsky e a dupla reversibilidade de seu personagem em humano/animal, que em cena tenta acossar uma das ninfas, apresenta ao público, ao final, a possibilidade do prazer sexual solitário através da indicação de uma masturbação. A presença desse 
realismo grotesco é ressaltado por um editorial da época no jornal francês Le Figaro (19I2 apud PORTINARI, 1989, p. I I8):

Aqueles que mencionam arte e poesia a propósito desse espetáculo estão nos ridicularizando. Não se trata de poesia pastoril nem de produção profunda. Tivemos um fauno inconveniente com vis movimentos de bestialidade erótica e gestos despudorados. Justas vaias acolheram a excessiva pantomima desse corpo de bicho mal construído, horrendo de frente e mais horrendo ainda de perfil. O verdadeiro público nunca aceitará esse realismo grotesco.

A presença desse corpo "mal construído" e "horrendo" trouxe para a cena da dança a desconstrução de uma corporalidade presa, até então, pela excessiva idealização e pela rigidez dos padrões da estética clássica.

Nijinsky deixa de lado a imagem sublimada presente nos balés românticos e incorpora, em seus movimentos, nas relações estabelecidas entre o dentro-fora, a realidade grotesca. Nessa coreografia, o grotesco atua como catástrofe (SODRÉ; PAIVA, 2002), realiza uma quebra abrupta de cânones e apresenta uma de/formação. Todas as ressalvas feitas pelos críticos da época resultaram em uma maior procura pelo público, que queria, por meio de seu voyerismo, averiguar in loco a condição da besta erótica.

Vale a pena abrir aqui um parêntese na intenção de tecer similaridades sobre a ferocidade dessa crítica, do início do século $X X$, com uma outra feita no final desse mesmo século, por Arlene Croce, na revista The New Yorker (1994). Essa crítica, ao analisar o espetáculo Still Here, de Bill T. Jones, mostra-se altamente chocada com a presença no palco de imagens de pessoas aidéticas, gordas, com deformidades físicas ou com doenças terminais e declara que essas pessoas são "vítimas da arte" de Bill T. Jones e que o palco não é o espaço para sua apresentação e a elas não cabe outra escolha a não ser de serem doentes.

Assim, analogicamente ao editorial apresentado no jornal Le Figaro, 80 anos depois outra famosa revista publica um artigo contendo o mesmo tom de repúdio às diferenças, solicitando o não apagamento do corpo idealizado na dança. 
No século $X X$, os preceitos instaurados pela dança moderna, que surgem em contraposição aos cânones do balé clássico, trazem para o âmago da discussão a busca pela liberdade de expressão do movimento e, consequentemente, inicia-se uma reflexão sobre o corpo que dança.

Além da dança, as demais artes, aliadas ao paradigma da modernidade, instauram revoluções artísticas contra a arte acadêmica burguesa, provocando uma rebelião contra a beleza, ao colocar a própria presença do feio na cena e sem dissolvê-lo em sua bela re(a)presentação.

Como uma das representantes da dança moderna, pode-se perceber, nas obras de Mary Wigman, a presença do grotesco imbuído dos reflexos do horror das guerras e de conflitos existenciais, como na coreografia solo A bruxa, de 1914. Nessa coreografia, Wigman, envolta pela estética expressionista explora, no chão, formas de locomoção e de expressão de um corpo sofrido e, por que não, também grotesco, já que uma bruxa, além de ocultar poderes sobrenaturais que podem de uma forma ambígua trazer sortilégios ou rogar malefícios, é sempre representada por uma corporalidade envelhecida, circunscrita por um exacerbado processo degenerativo. Ciane Fernandes (2003, p. 62), ao analisar nessa obra de Wigman a presença do princípio labaniano da harmonia, destaca que essa coreografia é circunscrita pelo espaço do entre, pois, ao abordar conceitos como harmonia e desarmonia, grotesco e sublime, essa obra possibilita a articulação desses conceitos como num jogo de espelhos não paralelos, ao mesmo tempo em que as proporções do monstro permitem o emergir de uma memória não-humana.

Fernandes (2003, p. 62) ressalta que “um intérprete 'iluminado' é aquele que não apenas inclui a diferença, mas reconhece, explora e expõe a beleza harmônica de seus próprios monstros, reverenciando a terra e o chão tanto quanto o céu e o espaço". Nesse sentido, como aponta Gil (1994), o monstro não se situa fora do domínio humano, mas no seu limite, com uma alteridade móvel.

Apesar da dança moderna iniciar uma busca pela expressão individual do movimento, os corpos que fizeram parte desse cenário ainda continuaram presos a ideais, só que agora vinculados a diferentes paradigmas técnicos, filosóficos e estéticos de cada escola modernista. 
Em uma análise sobre o processo de aprendizagem técnico da dança, lannitelli (2004, p. 3 I) enfatiza que

[...] técnicas desenvolvidas a partir da estética de um único coreógrafo apresentam movimentos particulares da estética daquele artista. Enquanto tal treinamento contribui pluralizando a experiência do aluno, ele pode também condicionar, bloquear e camuflar a sua expressão pessoal.

Nesse sentido, se para os próprios "corpos normais", a sistematização do ensino da técnica de dança moderna trouxe uma ênfase no aspecto qualitativo da habilidade técnica em detrimento da expressão individual, é claro que os corpos com deficiência nem sequer conseguiram se aproximar desses espaços de ensino-aprendizagem da dança moderna e, muito menos, participar do seu produto estético.

Como já foi citado anteriormente, com a dança pós-moderna, surgida nos anos 1960, é que as propostas cênicas começaram a desvencilhar o corpo e a própria dança de atitudes estéticas demarcadas pela dança moderna (MATOS, 2000), resultando em experimentalismos e visões de corpos não considerados, até então, estéticos para a dança. (BANES, 1994) Em paralelo a dança pós-moderna americana, outras propostas surgiam, como o butô japonês e a dança-teatro de Pina Bausch, cujos movimentos estéticos também emanavam outras visões do corpo que dança.

Nos anos 1980 surge uma tendência da dança contemporânea que parte de uma pesquisa sobre o corpo, mas, ainda relacionada a uma virtuose técnica dos bailarinos, explorando o risco do movimento, a energia, a força, outras dimensões espaciais como a horizontalidade, rolamentos, giros, decomposição e repetição do movimento, com a fisicalidade como um dos pilares centrais, como pode ser exemplificado pelo trabalho do grupo LaLaLa Human Steps, do Canadá, cujo corpo também fugia dos padrões esperados, validando a agilidade, a força física e a exploração da horizontalidade fora do chão. Se, nessa perspectiva, a extrapolação dos limites físicos de um corpo normal é o foco almejado, logicamente, mais uma vez, aqui não há espaço para um corpo com deficiência. 
Por outro lado, pode-se encontrar nas obras de artistas como Maguy Marin a presença da estética grotesca. Em “May B”, de 198I, Marin, inspirada na obra do dramaturgo Samuel Becket, cria uma obra coreográfica repleta de citações em referência ao teatro e à pintura, cujos personagens - ao mesmo tempo patéticos e repulsivos, com corpos deformados e movimentos que apresentam tensões físicas, como falta de coordenação e paralisia, ou mesmo imobilidade - em algumas cenas apresentam-se com os rostos brancos e narizes falsos e em outras, repletos de lama.

Eles parecem estar num espaço de exílio/confinamento, com rotas repetitivas e, assim, empurram o espectador para um espaço de estranhamento e inquietações diante de suas próprias dificuldades de convívio com o “outro". Em alguns momentos coreográficos, o ritmo é marcado pelos pés dos próprios dançarinos e seus corpos, detentores de diferentes códigos culturais e linguísticos, expõem suas memórias pessoais e criam em cena uma polifonia de corpos errantes, sem uma definida localização espaço-temporal. Por essas questões, esses corpos formados/deformados exalam características do grotesco crítico.

Mudanças mais significativas na dança começam a acontecer a partir dos anos 1990, principalmente com grupos europeus como Les Balés $C$. de la B. (Bélgica), Sasha Waltz (Alemanha) e Wim Vandekeybus (Bélgica). No Brasil, trabalhos como os de Vera Sala (SP), Cena I I (SC), dentre outros, também despontam em suas pesquisas artísticas com o foco no criador-intérprete.

Esses artistas começam a buscar as especificidades de cada corpo que dança, explorando novas configurações do próprio movimento, além de, em alguns casos, buscarem a articulação da dança com novas mídias, com a ciência e as demais artes, influenciados pelos processos de globalização, o que acarreta formas distintas de organizar os "pensamentos do corpo que dança".

Para Schlicher (200I), coreógrafos dos anos 1990, como Sasha Waltz, Jêrome Bel e Meg Stuart, sabem que não há mais nada para ser inventado, tudo pode ser reapropriado e, assim, a imagem do corpo na qual estão interessados é anti-virtuosa e anti-heróica. $O$ ponto de partida frequentemente é o exame dos "defeitos" e "deficiências" de seus próprios corpos 
e das limitações/possibilidades físicas individuais. Além disso, a diferença presente em outros corpos torna-se um estímulo para a criação e, pela exploração do corpo do artista, promove a criação de espaços de interlocução e de deslocamentos.

A busca por discursos de um corpo singular, que possui uma lógica sensório-perceptiva, expressiva e cultural específica, contribui para o surgimento de uma nova vertente estética na dança contemporânea, em que o corpo é a apresentação de si mesmo, e essa linha, por sua vez, abre a possibilidade para que grupos compostos por bailarinos com e sem deficiência, como CandoCo (Inglaterra), DIN A I 3 (Alemanha), Pulsar (RJ) e Grupo X (BA) explorem as diferentes fisicalidades e singularidades na dança.

Como já foi dito, é curioso notar que o interesse pela diferença e alteridade também está presente em trabalhos de coreógrafos e de artistas contemporâneos sem deficiência, nos quais a busca pelo entendimento da diferença presente em outros corpos torna-se um estímulo para a criação; a transformação do corpo do artista sem deficiência promove a criação de espaços de interlocução e deslocamento com a im/perfeição.

Assim, o que antes devia ser ocultado, por ser considerado um defeito ou uma falta, passa a ser revelado e transformado em um elemento gerador de possibilidades discursivas do corpo. Isso pode provocar novas percepções, tanto no processo de criação, quanto no processo de fruição e, assim, tanto os artistas quanto o público passam a ser remetidos às suas próprias incompletudes a partir do olhar e do contato com o corpo do outro, numa relação direta entre ambivalência e im/perfeição. Em ambas as vertentes corpos sem deficiência que buscam incorporar as diferenças e os grupos com bailarinos com e sem deficiência - os diálogos desses corposmídias da dança têm possibilitado uma construção estética na qual a categoria do grotesco pode assumir um caráter transgressor e crítico, apresentando a especificidade de cada corpo dançante e as teias de relações que podem ser criadas e pesquisadas, criando zonas de estranhamento, de encontros, desencontros e de desterritorialização.

Quando nos referimos à visibilidade desses trabalhos e à receptividade do público, no entanto, fica claro que a presença desses corpos com deficiência 
nos circuitos tradicionais da dança ainda é insignificante. Por mais que se fale na igualdade pela diferença, os corpos trans/formados dos dançarinos com deficiência ainda permanecem relegados a superfícies dissimuladas.

\section{NOTAS}

I Aura aqui é entendida no sentido benjaminiano, como "uma figura singular, composta de elementos espaciais e temporais" (BENJAMIN, 1985, p. 170) que, no caso da arte, seria a necessidade de uma sensibilidade especial e a existência única da obra. Para Benjamin, esse conceito torna-se inexistente na arte na era da reprodutibilidade técnica. Entretanto, aqui, opostamente, o balé, ao estilizar as danças populares, busca dar ao popular uma aura artística, criando diferenciações entre a alta e a baixa cultura. 



\section{CARTOGRAFANDO ESPAÇOS FRONTEIRIÇOS: A PRODUÇÃO DA DANÇA INCLUSIVA (DISABLED DANCE) NO BRASIL}

Desde as últimas décadas do século $X X$, o termo inclusão ganha cada vez mais espaço nos discursos oficiais e nas políticas públicas de diferentes países, em decorrência das ações promovidas por grupos que se encontram à margem da sociedade e que têm buscado validar suas vozes, organizando-se como um movimento social, fazendo com que os demais sujeitos não apenas os percebam na diversidade, mas que validem seus diferentes modos de estarem no mundo.

Segundo dados da ONU (2006), temos uma população mundial com cerca de 500 milhões de pessoas com deficiências, $80 \%$ delas localizadas em países em desenvolvimento. Os dados do Censo do IBGE de 2000 apontam para a existência de 24,5 milhões de brasileiros com deficiência,' o que representa $14,5 \%$ da população. 
Apesar das pessoas com deficiência estarem hoje mais "visíveis", ainda ocorre muita discriminação por parte da população majoritária que, de modo consciente ou inconsciente, estabelece padrões de expectativa de normalidade para seus atores sociais. Esses padrões são metanarrativas, ${ }^{2}$ que apontam para categorias fechadas e totalizantes, sustentando conceitos de normalidade e representações estáticas de gênero, cultura, classe, sexualidade e habilidade física. Assim, aqueles que estão longe dos padrões esperados, ou seja, as minorias, como é o caso das pessoas com deficiência, são excluídos, estigmatizados e delimitados em suas ações no meio social.

Uma das formas encontradas por esses grupos minoritários para romper com esse paradigma é a instalação de políticas afirmativas (ou compensatórias), que se tornam temporariamente necessárias para garantir seus direitos como cidadãos no que se refere a aspectos como acessibilidade, igualdade de direitos, mercado de trabalho, inclusão social e cultural. Mesmo em sociedades que já possuem firmes políticas inclusivas e os direitos das pessoas com deficiência são garantidos, ainda se percebe uma tensão entre os diferentes grupos sociais, que abrange também seus referenciais culturais.

As diretrizes inclusivas que têm sido delineadas nos documentos oficiais no Brasil esbarram, primeiramente, na dificuldade de sua real implantação, devido à própria estrutura social perversa, que instaura uma distribuição desigual dos bens simbólicos e materiais. Consequentemente, há ausência de efetivas ações públicas e de representatividade das pessoas com deficiência em cargos estratégicos, bem como muitas das barreiras culturais que permanecem em nossa sociedade são decorrentes, em sua maioria, da falta de informação da população.

No cotidiano, as pessoas com deficiência ainda encontram dificuldades em realizar, por exemplo, uma simples locomoção, em decorrência das barreiras arquitetônicas das cidades, ou da escassez de transportes públicos adaptados, que facilitem seu livre acesso.

No âmbito educacional, pode-se visualizar a preocupação de muitos educadores com a integração dos excluídos, objetivando uma equidade da educação, o que ainda poucas vezes vem sendo alcançado com êxito. Muitas dessas ações acabam direcionando-se ao reconhecimento da diver- 
sidade e não à emancipação - no sentido freireano - desses sujeitos, pela falta de adequação das condições do ensino público e privado.

Infelizmente, as propostas inclusivas em andamento, em sua maioria, estão sendo vistas apenas como uma ocupação espacial, como se, na cotidianidade do território escolar, todos já estivessem supostamente inclusos, libertos de ideologias e contradições. Assim, o despreparo dos professores da rede pública e privada, a ausência de recursos, a baixa expectativa em relação aos alunos com deficiência e a carência de referenciais de êxito de seus pares na escola, contribuem para uma nova perspectiva de exclusão dentro da suposta inclusão.

Ao mesmo tempo, é necessário salientar que as políticas inclusivas para a educação, alardeadas nos documentos e na mídia, configuram-se em um discurso oficial que na realidade não prioriza metas transformadoras para a educação, passando a ser uma política de intenções, em decorrência de um plano econômico nacional que colocou em primeiro plano, durante muitos anos no Brasil, o atendimento às exigências dos acordos feitos com organismos internacionais e/ou órgãos financiadores internacionais como o Fundo Monetário Internacional (FMI) e o Banco Mundial.

No que se refere às questões culturais, ainda são praticamente inexistentes políticas governamentais que favoreçam a produção artística e o acesso da pessoa com deficiência no campo das artes, seja na formação, na produção ou no acesso aos bens culturais. É importante ressaltar que não se aborda aqui a perspectiva da arte como terapia, pois essa sempre foi e é muito utilizada nos programas de reabilitação.

Analisando à luz dos Disability Studies, ${ }^{3}$ esse breve panorama referente às características das questões políticas, sociais e culturais da deficiência, no Brasil, pode-se afirmar que ainda há um predomínio do modelo médico, o que leva à patologização da deficiência. Por outro lado, percebe-se na sociedade civil um movimento das pessoas com deficiência na tentativa de validar suas vozes, diminuir as relações hierárquicas de poder entre as pessoas com e sem deficiência e transformar a realidade atual.

Para Shakeaspeare (1996), existem dois modos de percepção das pessoas com deficiência enquanto grupo: um direciona-se para a perspectiva 
médica ou à classificação física do impairment, ${ }^{4}$ e tem como ênfase a deficiência em si e suas características patológicas; e "no segundo foco a deficiência tem sido concebida como resultado de processos sociais ou como uma categoria criada ou construída." (SHAKEASPEARE, 1996, p. 3) Assim, no modelo social, a deficiência é resultado de uma condição social, cultural e política, a qual coloca pessoas com diferentes fisicalidades reféns da incapacidade social de lidar com a diferença. (BARNES, 2003; DINIZ; MEDEIROS, 2004; FONTES, 2004)

Essas duas perspectivas amplamente discutidas pelos Disability Studies apontam-nos duas indagações: se a identidade não é mais fixada em uma única instância social - descentramento de si e do espaço social - (HALL, 1997), o que lhe dá uma caráter oscilatório e provisório, feito no cruzamento de seu referencial com o do outro, como as pessoas com deficiência se percebem nesse contexto, já que, ainda hoje, sua identidade não foi descolada pela maioria da sociedade da sua falta, da sua deficiência? E, nesse contexto, como está sendo abordado o corpo com deficiência na dança?

\section{Disabled Dance ou dança momentaneamente inclusiva}

O uso do termo disabled dance demonstra uma necessidade de demarcar um território cultural (que não deixa de ser político e social), caracterizando-se como uma produção artística feita por artistas com deficiência, o que lhe imprime uma singularidade. Como cita Pick (1992, p. 2 I, tradução nossa), "a arte com deficientes pode ter um diferente tipo de grandeza daquela arte dos não deficientes, pois a primeira é baseada na situação e experiência única de ser deficiente."

Como exemplo das questões que envolvem o uso desse termo, nas entrevistas realizadas com os quatro grupos de dança contemporânea envolvidos na pesquisa, os dançarinos demonstraram não se identificar com o termo dança inclusiva por considerarem que esse termo vislumbra apenas a integração e, para eles, o que produzem é dança, tendo nos grupos dançarinos com fisicalidades diferenciadas do ideal de corpo da dança. Para 
muito deles, no cenário brasileiro, essa nomenclatura pode implicar em outros estigmas como, por exemplo, a dúvida se esses bailarinos podem ser definidos ou não como artistas ou mesmo se seu produto é arte. Em suas palavras:

[...] foi necessário usar esse nome no início, mas nunca gostamos porque, a gente achava que isso já era excludente. Também não era uma coisa que dizia que a gente está fazendo arte. Simplesmente parece que você está fazendo outro tipo de coisa que não é arte. (Sílvia Renhe, dançarina e coreógrafa da "Ekilíbrio")

[...] a dança que a gente trabalha é a dança contemporânea que ela já tem essa diversidade de corpos. Então que inclusão que é essa se os corpos já são diversos, entendeu? (Alessandra Bittencurt, dançarina da "Limites")

eu até acho que não se ajusta muito a gente, quando as pessoas usam esse nome, esse termo dança inclusiva ou qualquer outra forma de, ah, o dançarino com deficiência. Na nossa estética, mesmo no palco com Edu, eu sinceramente vejo como um dançarino com sua particularidade. A gente trabalha muito isso: eu, grandão e magro, Edu na cadeira, Juliana magrinha e baixinha, Fafá com os cinqüenta anos dela. Lindão! (Hugo Leonardo, dançarino do "Grupo X”)

Vale ressaltar que todos os grupos analisados são formados por dançarinos com e sem deficiência, e que essa configuração pode ser decisiva para a não adoção de um termo específico como disabled dance - que na língua portuguesa não se torna tão significativo -, o que muitas vezes remete a trabalhos exclusivos de artistas com deficiência.

Ao mesmo tempo, em nenhum desses grupos analisados os dançarinos com deficiência assumem papéis decisivos como, por exemplo, coreógrafo ou diretor, sendo no máximo apresentados como cocriadores, o que demonstra ainda a predominância da relação de poder da pessoa sem deficiência sobre a pessoa com deficiência.

Em alguns países, como a Inglaterra, o trabalho de dança inclusiva - por enquanto adotaremos esse termo adaptado ao português -, já vem se organizando há pelo menos duas décadas. Vale ressaltar que a Inglaterra possui 
claras políticas públicas, nos campos educacional e cultural (THE HUMAN RIGHTS ACT, 1998), as quais promovem a inserção da pessoa com deficiência e reconhecem a disabled dance como um tipo de produção artística específica, com alguns fundos financeiros de apoio à sua produção como o da Loteria (Big Lottery Funds).

O trabalho do CandoCo Dance Company pode ser um exemplo positivo de ações pessoais desenvolvidas nesse país que conseguiram uma amplitude internacional, tanto de público, quanto de crítica. Esse grupo foi fundado por Celeste Dandeker e Adam Benjamin, em 1991, e apenas ela permaneceu na companhia, até 2007, realizando a direção artística do grupo. Dandeker foi uma dançarina que tem em sua memória corporal a experiência de ter sido andante,$^{5}$ tendo trabalhado durante seis anos na London Contemporary Dance Theatre até que um acidente no palco tornou-a paraplégica.

Uma das obras mais conhecidas desse grupo é o videodança Outside in que apresenta uma dupla visibilidade: a coreografia e a deficiência, o estar dentro e o estar fora. Utilizando uma linguagem contemporânea, o grupo CandoCo insere na cena corpos que possuem uma limitação física real, cuja pesquisa de movimentos baseia-se exatamente nas diferenças: estampa-se as múltiplas fisicalidades, conjunções/disjunções e interações desses diferentes corpos, que, nesse contexto, criam uma gramática própria, explorando suas possibilidades e vulnerabilidades. Os corpos dos dançarinos não tentam camuflar seus limites físicos. Além das ações artísticas, o grupo promove o treinamento de dançarinos e cursos na área da educação visando a favorecer práticas integrativas em dança.

Dentre outras ações desenvolvidas na Inglaterra, foi realizado, em 2002, um congresso denominado Dancing Differently? Nesse fórum, os artistas com deficiência diagnosticaram barreiras encontradas na dança, dentre as quais, podemos citar: barreiras culturais dentro da própria dança sobre quem pode ser um dançarino e o que é dança; barreiras durante o acesso à educação formal e não formal e às artes; e diferenças culturais dentro da sociedade sobre o que é deficiência e sobre quem é o sujeito com deficiência.

Como exemplo de relatos sobre essas barreiras, David Toole, em um artigo escrito para a revista Animated (2002), apresenta um depoimento 
sobre as dificuldades encontradas quando resolveu ser um performer. Para Toole - ex-dançarino da CandoCo e participante de alguns projetos do grupo inglês de dança contemporânea DV-8 - as opções para as pessoas com deficiência são muito limitadas e uma carreira na área da performance não é vista como viável.

Além disso, mesmo em áreas nas quais é "esperada" a atuação da pessoa com deficiência, esta tem que conseguir demonstrar que faz o trabalho meIhor que uma pessoa sem deficiência. Toole passou nove anos trabalhando nos correios de sua cidade até conseguir iniciar sua incursão na arte.

Ao narrar sua experiência na área da Dança, Toole aponta que - nos anos em que estudou no Laban Center, graças a uma bolsa de estudos recebida após participar de um rápido workshop do CandoCo - ele praticamente não aprendeu nada sobre técnica, pois nem ele e nem seus professores sabiam como lidar com sua fisicalidade - David Toole possui deficiência física, tendo as duas pernas amputadas, e uma ampla mobilidade fora da cadeira de rodas usando suas mãos e braços. Em contraposição, Toole narra que seus anos de estudo no Laban Center foram de aprendizado sobre estar com outros dançarinos e coreógrafos.

Nesse mesmo artigo, o bailarino conta ainda que, quando passou a fazer parte do CandoCo, percebia pessoas na plateia ligeiramente chocadas com sua fisicalidade e outras com uma simpatia pelo grupo. Para ele, o sucesso do CandoCo não é o tipo de resultado esperado de um "disabled dance group". Em situações sociais, Toole teve sua identidade quase sempre questionada. Quando se apresentava para estranhos como dançarino, ele precisava dar mais explicações sobre esse fato.

Nesse relato de David Toole fica patente que a expectativa da sociedade majoritária ainda relaciona, de uma forma direta, a identidade do sujeito com deficiência com o modelo médico da deficiência (a patologização do não “normal”), traduzindo uma parte pelo todo e colocando-o, por esse motivo, à margem da sociedade.

Por outro lado, analisando a organização do fazer artístico em dança de alguns grupos que possuem dançarinos(as) com e sem deficiência, como é o caso do trabalho Outside in, do CandoCo, com a participação de David 
Toole, novamente pode-se afirmar que o corpo do(a) dançarino(a) com deficiência pode posicionar-se como um corpo político, que rompe com representações identitárias estagnadas e cuja diferença presente nesse corpo possibilita que suas próprias experiências transitem na obra coreográfica.

Apesar de se ter a crença de estarmos iniciando uma mudança de paradigma, ressalta-se que, muitas vezes, espetáculos de dança que incluem dançarinos com deficiência podem também servir para uma visão estereotipada desses sujeitos por apresentarem, de forma liminar ou explícita, o sujeito com deficiência como herói de si mesmo, alvo da compaixão ou alguém que busca incessantemente a proximidade com o paradigma da normalidade.

Para discutir a presença dessas perspectivas no cenário cultural brasileiro, apresentamos a análise do $1^{\circ}$ Festival Internacional Arte sem Barreiras, que aconteceu, em 2002, no Teatro SESIMINAS, em paralelo às atividades do $1{ }^{\circ}$ Congresso Internacional Arte sem Barreiras, na PUC-MG.

\section{A de/limitação do festival}

O “Arte sem Barreiras", em sua edição nacional, pode ser considerado como um dos maiores eventos na área de arte inclusiva, no Brasil, ao abordar exclusivamente trabalhos artísticos e educativos direcionados para a pessoa com deficiência, possuindo uma Mostra de Dança como um circuito segmentado.

O Festival faz parte do Programa Arte sem Barreiras, que tem como origem o programa americano Very Special Arts (VSA). Nos Estados Unidos, esse projeto está filiado ao John Kennedy Center for the Performing Arts e foi fundado em 1974, por iniciativa de Jean Kennedy Smith, tendo hoje representações em mais de 80 países. O Brasil tornou-se filiado ao VSA em I988, sendo que, em 1989, o comitê do VSA no Brasil passou a ser apoiado pela Funarte (MINC), de uma forma não oficializada, apesar de funcionar dentro de sua sede no Rio de Janeiro.

Albertina Brasil Santos, ex-presidente da Associação Vida, Sensibilidade e Arte, representava o VSA no Brasil. Após 15 anos, em 2003, esse programa 
passou a ser gerenciado pela própria Funarte e coordenado pela musicoterapeuta Rita Maria Aguiar, ex-membro da diretoria anterior da associação. Esse projeto permaneceu apenas por um curto período de tempo, atuando nas dependências da FUNARTE.

Vale a pena registrar que, no que se refere às questões culturais no Brasil, ainda são praticamente inexistentes políticas governamentais que favoreçam a produção artística e o acesso da pessoa com deficiência no campo das artes. Das raras atividades deflagradas, o único em nível nacional foi o Programa Arte sem Barreiras. A sua mais efetiva linha de atuação relacionou-se às ações no campo educativo, visando à inserção social da pessoa com deficiência e ao desenvolvimento de atividades artístico-educativas que envolvam pessoas com e sem deficiência.

Os objetivos desse programa, durante seu período de funcionamento, entretanto, não tiveram seu papel devidamente esclarecido como fomentador da arte como campo de conhecimento, já que sua diretriz principal enfatizava a promoção da cidadania e tinha como objetivo maior a inclusão social e não a cultural:

O programa promove a arte, a educação e a expressão de jovens e adultos, fortalecendo dessa forma o espírito humano e melhorando a qualidade de vida de todos. Considera que a experimentação com a arte incrementa o crescimento pessoal, educativo e profissional. $O$ uso das linguagens da arte por pessoas com necessidades especiais promove sua aceitação e inclusão em todos os aspectos da vida. (FUNARTE, 2006)

Além disso, ainda apresenta uma compreensão de arte numa perspectiva universalizante, bem como é apontada a possibilidade de um uso instrumental da arte, como pode ser visto no sítio eletrônico do programa: "A arte, como linguagem universal, é um meio para a expressão de sentimentos, percepções e sensibilidades inerentes ao ser humano, possibilitando olhares diferenciados sobre a realidade e agindo como importante vetor para o crescimento pessoal, educativo e profissional." (FUNARTE, 2005) 
Essa perspectiva se distancia da visão da arte na contemporaneidade, abrindo brechas para conceituações equivocadas de uma "linguagem universal" da dança, por exemplo, o que tira a singularidade das mediações construídas pelo ser humano em seu próprio entorno, bem como o próprio fazer artístico não se torna o alvo central de seus objetivos.

Após dois anos da incorporação desse Programa pela Funarte, em 15 de dezembro de 2005, o Ministério da Cultura anunciou - em uma carta de intenções assinada entre a Funarte, o Projeto Arte sem Barreiras e as Loterias da Caixa - uma parceria que pretende utilizar um milhão de reais em benefício desse programa, através dos recursos arrecadados pelas loterias, "que sempre foram usados em programas e projetos de cunho social principalmente na área da cultura e educação." (FUNARTE, 2005)

Entretanto, até 2006, ${ }^{\circ}$ ○ Arte sem Barreiras não anunciou quais serão os mecanismos para o pleito desses recursos. Em entrevista, a coordenadora do programa salientou o momento de mudança, mas ainda sem definições:

A gente está em mudança. Antes os projetos chegavam e a gente fazia uma contrapartida. Por exemplo, [narra a organização de um evento] nós entrávamos com a orientação, com os folders, com os textos que é uma coisa que a gente faz e gosta muito de fazer. Fazendo essa parceria e a realização lá com um apoio local [...]. Nós estamos ainda no meio do caminho. [...] então daqui pra frente nós vamos trabalhar com editais. (Rita Aguiar, 2005)

Apesar de o Programa ter como uma das vertentes de sua atuação "o incentivo e difusão profissional de trabalhos em condições ${ }^{7}$ de circular em espaços culturais não-segmentados", ${ }^{8}$ no que se refere especificamente às políticas culturais, tanto esse programa, quanto o próprio Ministério da Cultura não possui ações efetivas para a profissionalização na dança -,e quase que em de nenhuma outra área artística -, e raramente promovem a apresentação de produtos de artistas com deficiência nos circuitos não segmentados.

Como estava destacado, no sítio eletrônico da Funarte, sobre o Programa Arte sem Barreiras (2004), a sua ação direciona-se à “discussão e elaboração 
de políticas públicas de ensino através da arte e realiza procedimentos com arte para pessoas com necessidades especiais". 9

Mesmo constando como sua missão um destaque aos aspectos educativos, o "Arte sem Barreiras" encontra-se sob o guarda-chuva da Funarte/ Ministério da Cultura, o que contribui para questionamentos sobre os espaços fronteiriços da arte como produto artístico e como processo educativo e sobre quais estruturas e recursos financeiros (educação/cultura) devem subsidiar suas importantes, porém distintas e complementares ações.

Ao mesmo tempo, indaga-se também o papel da própria Funarte no delineamento de políticas públicas inclusivas para a arte, visto que, no Brasil, as políticas federais de incentivo à arte, mais especificamente no que se refere à dança (manutenção, produção e circulação), são quase inexistentes, pois se limitam a editais e não a um plano político continuado para a cultura. ${ }^{10}$

Ao analisar as diretrizes do Programa Arte sem Barreiras, pode-se perceber, pelo seu discurso e nas mostras artísticas que possuem o seu apoio, que esse projeto sustenta uma visão de arte como processo, valorizando a produção amadora da dança. Isso pode ser ressaltado na fala do ex-presidente da Funarte, Antonio Grassi (2005, grifo nosso), na abertura de um evento com a tarja desse programa: "No Brasil, 24 milhões de pessoas têm algum tipo de deficiência, o que corresponde a $14,5 \%$ da população do país. O objetivo desse evento [Mostra Rio de Arte sem Barreiras] é apresentar à sociedade a produção artística de pessoas com deficiência e discutir a inclusão social através da arte”.

Além do mais, alguns conceitos como superação e comoção, normalmente, muito explorados pela mídia, também são associados pelo discurso oficial como uma valoração positiva. Isso pode ser percebido, por exemplo, no discurso do ex-ministro da Cultura, Gilberto Gil, no qual há uma referência ao lançamento do Programa Arte sem Barreiras, em 2004:

Lembro-me bem da avalanche de emoções que tomou conta de todos nós que assistíamos às apresentações de danças, músicas, cantos, poesias, artes plásticas, performances teatrais. Surpresas atrás de surpresas, lições humanas e estéticas que jamais esqueceremos. Aquelas ações, que hoje se transformaram 
em um constituinte programa de inclusão, podem ser resumidas um uma única palavra: superação. (FUNARTE, 2005)

Essas perspectivas acabam, também, se refletindo na programação de seus eventos e em outras ações que vêm sendo desenvolvidas ao longo destes anos no Brasil. Para entender um pouco mais esses aspectos, consideraremos como alvo central de análise as produções de dança apresentadas no $1{ }^{\circ}$ Festival Internacional Arte sem Barreiras, em 2002. É importante frisar que, nesse período, a Funarte apenas apoiava o programa, não tendo sido responsável pela sua formatação.

É interessante observar, primeiramente, o delineamento da programação. Durante cinco dias, apresentaram-se 30 grupos nacionais, 15 deles participaram da mostra vespertina, que tinha um caráter amador, ficando o restante dos grupos na mostra da noite. Muitos desses grupos amadores são mantidos por instituições de reabilitação, escolas regulares ou especiais, sendo alguns deles dirigidos por terapeutas, educadores ou profissionais da educação física, com ínfimo conhecimento de dança. Esse é um dos aspectos que favorece o surgimento de conceitos equivocados sobre dança e a manutenção da visão terapêutica e das relações de poder do não deficiente sobre a pessoa com deficiência.

Além dos 15 grupos identificados pela comissão organizadora como semiprofissionais e profissionais," foram convidados os Grupos "Dançando com a Diferença", da llha da Madeira, Portugal, dirigido pelo brasileiro Henrique Amoedo e mantido pelo Serviço de Arte e Criatividade da Secretaria Regional de Educação daquela ilha, e a companhia profissional inglesa CandoCo, dirigida por Celeste Dandeker, cuja vinda ao Brasil foi parcialmente subsidiada pelo British Council.

As coreografias apresentadas pelos grupos da mostra noturna podem ser caracterizadas, nesta análise, pelo seguinte perfil estilístico (auto-identificação): um grupo de balé; dois grupos de dança moderna; dois grupos de dança de salão; um de dança de rua; dois de folclore; um com estilo não definido (mistura de folclore e dança de salão); cinco de dança contemporânea e uma performance. 
Desse cenário, apenas quatro dos cinco grupos aqui configurados como dança contemporânea apresentaram um trabalho diferenciado, em que se percebe nas obras coreográficas uma busca pela dialogia com os diferentes corpos, sendo que alguns grupos obtiveram um resultado mais significativo do que os demais. Esses grupos ficaram diluídos na programação geral da noite, misturados com os amadores, sendo que vários destes amadores se intitulam profissionais e apresentam o modelo de dança esperado pela plateia: virtuose e e(co)moção.

Na perspectiva de Sodré e Paiva (2002), trabalhos artísticos que, na sua categoria estética, enfatizam a reação afetiva mais do que seus elementos constitutivos podem fazer com que a relação estabelecida com a obra seja uma impressão de natureza emocional. Assim, neste caso, por se tratar de pessoas com deficiência, as emoções de piedade e horror (trágico) ou espanto e riso (grotesco) são normalmente associadas.

Os trabalhos apresentados pela tarde, com características eminentemente amadoras, representam o senso comum do que é dança, com os mesmos equívocos encontrados em alguns festivais de encerramento de academias que não possuem profissionais com uma sólida formação artística e estética em dança, o que implica modelos chavões que recaem, por exemplo, no uso de movimentos padronizados, na falta de exploração espacial e temporal e na inexistência de pesquisa, seja ela temática, de movimento ou artística. Aliado a tais fatores, esses trabalhos apresentam outro elemento complicador: a forma como o corpo com deficiência é abordado na obra.

Um dos primeiros indicativos dessa abordagem fica estampado na escoIha de alguns nomes adotados pelos grupos: "Vencendo limites, conquistando horizontes...", "Arte de viver" e "Portadores da alegria", cujas adjetivações colocam os sujeitos com deficiência como seres encantados e/ou enfatiza-se a sua capacidade de superação.

Esse aspecto da superação é levado ao extremo em uma declaração da coreógrafa e fisioterapeuta Fernanda Bianchini, do Grupo de Dança do Instituto de Cegos Padre Chico, ao colocar no programa do evento os seguintes dizeres: "tudo se torna possível quando se tem força de vontade [...]; uma bailarina deve sempre olhar para as estrelas, ainda que não as enxergue”. 
Além de solicitar uma superação impossível para uma pessoa cega, essa fisioterapeuta sustenta uma normalização do corpo do deficiente, no que se refere ao modo de percepção, afinal, provavelmente, a pessoa com cegueira tem uma forma diferente da representação mental da estrela do daquela da pessoa que enxerga.

Outras representações foram identificadas em algumas coreografias selecionadas para o horário "nobre”, cujos grupos eram vistos como semiprofissionais e profissionais pela organização do evento, todavia, alguns deles, apresentavam discursos muito similares aos trabalhos amadores.

Em algumas dessas coreografias, foi encontrada uma perspectiva terapêutica da dança para a pessoa com deficiência, visando à expressão do indivíduo ou mesmo à reabilitação. A terapia traz no seu âmago a promoção da saúde e, no caso da dançaterapia, utiliza-se dos processos criativos da dança para alcançar a cura de um "corpo doente". ${ }^{2}$

Nesse contexto, a dança faz parte de um processo que não busca chegar a um produto artístico. O perigo passa a ser quando essa fronteira equivocadamente é dissolvida, confundindo-se o processo de reabilitação com um resultado artístico. Essa questão foi suscitada durante o evento, após a apresentação do grupo Crepúsculo $(\mathrm{BH})$, dirigido por duas terapeutas ocupacionais, uma delas com formação em dança clássica e dança moderna, na Fundação Clóvis Salgado, e uma professora de educação especial.

A coreografia “Extensão”, apresentada pelo grupo Crepúsculo, mostra, já perto do seu final, a entrada de um rapaz que é carregado e colocado no centro do palco sob uma bóia e seus movimentos são claramente percebidos como involuntários. Enquanto os demais membros do grupo dançam, ele permanece o tempo todo nessa posição, com espasmos. A cena se desfecha, o grupo agradece, aos poucos vão saindo e o rapaz fica no meio do palco, encravado na bóia, até que duas pessoas retornam e o carregam para fora do palco.

Esse jovem é portador de paralisia cerebral quadriplégica espástica com atetose $^{13} \mathrm{e}$, segundo as diretoras do grupo, ele tem um grave quadro motor com grande espasticidade e movimentação involuntária, sem uma comunicação oral (apenas pela expressão facial) tendo, porém, preservada a inteli- 
gência. A coreógrafa afirma que o rapaz tem "consciência de seus desejos e aspirações” 14 e, por esse motivo, ele foi integrado ao espetáculo.

Diferentemente da posição das diretoras do grupo, consideramos que a questão a ser abordada aqui não se refere à possibilidade de inserção ou não desse jovem, mas sim como seu corpo é abordado na coreografia, o que suscita algumas questões: que conceito de dança permeia esse trabalho? Terá ocorrido algum movimento consciente e voluntário executado por esse jovem? Será que um processo terapêutico ou clínico, com a relação paciente-terapeuta, pode ser apresentado como um resultado artístico (dança-criador-intérprete-obra)? Onde ficam os limites entre o ético e o estético? Questionamentos à parte, grande parte do público responde co-movido pela apresentação.

Uma segunda leitura pode ser feita por meio de uma coreografia de hip hop apresentada nesse festival pelo grupo Bombelêla Dance Company (SP), na qual a relação de poder entre eficiente/deficiente é claramente desvelada. Inúmeras vezes, sobreposto ao fundo musical, é repetida, durante a coreografia de hip hop, a frase "apenas um corpo diferente", como se o simples uso da frase desse o aval e qualificasse a presença da pessoa com deficiência na dança.

Analisando essa intencionalidade semântica e as relações estabelecidas na coreografia, pode-se perceber que o dançarino diferente era apenas um corpo de passagem, cujo traço lançado no espaço coreográfico rapidamente se apagava, ficando à margem. Seu movimento foi, em muitos momentos, conduzido por aqueles que "dominavam" o modelo de movimento almejado ou, em outras ocasiões, esse corpo - com deficiência - era literalmente carregado na coreografia pelos demais dançarinos, com um sentido apenas de uma mudança de “arranjo” espacial, mostrando a sua dependência. Além disso, os ápices coreográficos evidenciavam a eficiência do corpo "normal" e a virtuose do solista do grupo, cujas ações em cena remetem ao seu papel de líder de mais uma tribo urbana (no sentido maffesoliano).

Essa estrutura se repetiu em várias coreografias, principalmente nas de dança de salão, cuja relação de poder masculino/feminino é transferida para 
a relação eficiente/deficiente. Essa perspectiva revela uma clara hierarquia de poder, em que os corpos com deficiência passam a ser corpos dóceis, no sentido foucaltiano, treinados para a subordinação.

Uma terceira via pôde ser percebida pela apresentação do grupo Integrarte (São Bernardo, SP), que apresentou uma coreografia de balé clássico muito bem ensaiada, com um corpo de baile com capacitação técnica e precisão musical, uma precisão provavelmente decorada pelos Surdos do elenco.

Essa é uma das maneiras pelas quais se impregna o paradigma da superação e da normalização, implicando que o corpo com deficiência seja um corpo simulacro que aparenta ser/ter o corpo do outro, o do não deficiente (homogeneização). Por outra via, esse padrão de normalização, que esteve muito presente de uma maneira geral no festival apresenta-se, no caso dos cadeirantes, como uma anulação do baixo ventre, valorizando os movimentos de braços e cabeça, o rodopiar das cadeiras, na tentativa de anular a parte do corpo ausente de controle de movimento.

Nesse modelo, volta à cena a importância do partner, a pessoa sem deficiência, para conduzir o espetáculo, o que nos traz outras indagações: se não estivesse em cena o bailarino andante, qual seria a dança, a estética, a surgir do corpo do cadeirante? Quais seriam suas possibilidades de movimento e que relações espaço-temporais seriam tecidas?

Esses aspectos implícitos nos três modelos acima tornaram-se despercebidos para a maioria da plateia. Durante quase todo o festival, notamos uma plateia vivaz, que ovacionava a cada virtuose feita no palco ou se comovia com coreografias cravejadas de apelos emocionais e de superação (afinal, são deficientes); assim, não importava como a dança era feita ou mesmo o papel do dançarino com deficiência. $O$ único dia em que a plateia esmaeceu, empalideceu e friamente permaneceu em seus assentos, foi durante a apresentação do CandoCo. Houve um estranhamento a um padrão de dança desconhecido pela maioria; surge, no palco, uma companhia que não recebeu nenhum destaque na divulgação da programação do evento, pois aparentava, para os desavisados, ser mais uma dentre outras. Em cena estão os corpos esperados pela plateia - dois dançarinos cadeirantes, uma 
dançarina com uma perna amputada, uma sem uma mão e três dançarinos sem deficiência -, mas o pensamento de dança é outro e complexo.

O CandoCo apresentou três coreografias, até então inéditas no Brasil, que fizeram parte de sua tournê 2002-2003: Phasing, de Jamie Watton, Sour Milk, de Javier de Frutos e Shadow, de Fin Walker. A direção artística dessa companhia optou por trabalhar com reconhecidos coreógrafos contemporâneos, com o intuito de quebrar tabus e percepções esperadas pela plateia com a inserção, na dança, do dançarino com deficiência.

Nessas coreografias, respeitando a intencionalidade e a especificidade de cada criador, as diferenças corporais e as singularidades dos dançarinos se interconectam e geram uma dança cujo significado está na obra, no corpo específico que dança, em suas conjunções e disjunções e não no conceito de ser deficiente. No trabalho do CandoCo, os dançarinos não possuem hierarquias, seus corpos transgridem as regras de normalidade/ anormalidade e "não tentam camuflar seus limites físicos mas trabalham no espaço do entre, isto é, no espaço de conjunção, ao explorarem a fisicalidade de cada corpo que interage e atua com e sobre o outro." (MATOS, 2002, p. 182)

É por essa via que se compreende o estado de estranhamento provocado pelo CandoCo à plateia do Festival. Naquele dia, ao final da apresentação, os presentes educados e friamente agradeceram, com breves aplausos, o impacto causado por aqueles corpos que, como mídia da dança, apresentaram uma linguagem ainda desconhecida para a maioria da plateia.

Todos os aspectos apresentados, a partir desta análise do festival, também oferecem contrapontos que se relacionam às questões educativas em arte/dança como, por exemplo: que bases filosóficas permeiam essas ações? Quais conceitos de arte/dança estão sendo difundidos com as pessoas com deficiências? E, quem exerce o papel de educador de arte/dança?

Em relação ao produto artístico, o ponto que queremos chegar refere-se à busca de conceitos sobre a dança feita com e para as pessoas com e sem deficiência. Afinal, quais são as especificidades de um corpo dançante, seja ele com ou sem deficiência? Como trabalhar diferentes singularidades 
e fisicalidades sem cair nas velhas dualidades do normal/anormal, uno/múltiplo, eficiente/deficiente?

De uma forma geral, a visibilidade do corpo com deficiência pode provocar indagações sobre o papel que vem sendo assumido por esses corpos, já que eles começam a ocupar espaços até então dominados pelos corpos ideais. Entretanto, a depender de suas opções, esses corpos também podem sustentar, com uma visão acrítica, a primazia dos corpos ideais ao procurar escamotear as suas próprias diferenças e tentar refletir uma falsa superação da deficiência, invocando a imagem de um corpo clássico e seus valores ideológicos.

É nesse sentido que ao considerar, numa acepção deleuziana, que a diferença se instaura na relação, nos agenciamentos, afirmamos que a maioria dos corpos dançantes apresentados nesse festival tornou-se visíveis por uma aparente inclusão espacial; entretanto, eles foram encobertos pelo fino manto da normalidade, o que faz com que eles permaneçam no que denominamos de superfícies dissimuladas, nas quais se disfarça de uma forma crua a diferença.

Contraposta a essa perspectiva, vemos a emersão de grupos de dançarinos com e sem deficiência, que tem afirmado na dança a qualidade artística de seus trabalhos. Muitos trabalhos contemporâneos - como os realizados pelas companhias CandoCo (Inglaterra), DV 8 (Inglaterra), Vertigo (Israel), DIN A/3 (Alemanha) e alguns grupos brasileiros - apresentam corpos que normalmente são considerados estigmatizados pela dança, e por meio de sua obra coreográfica levam a plateia a refletir sobre concepções estagnadas de corpo, dança e eficiência/deficiência.

A apresentação do dançarino com deficiência no palco, distante da perspectiva de fomentar o sentimento de compaixão, pode levar a plateia a dialogar e confrontar a história desse corpo com a história, valores e (pre) conceitos do seu próprio corpo, podendo, por esse caminho, provocar sentimentos desconcertantes, bem como desafiar as representações de corpo que são estabelecidas na dança. Assim, num viés deleuziano, esses corpos podem tornar-se um elemento perturbador da ordem instaurada, e com suas estórias inscritas na própria carne esses dançarinos "se dizem na diferença". 
Como toda relação entre processo/produto, a inserção de corpos diferenciais também traz implicações para o ensino da dança. Infelizmente ainda há uma enorme distância entre as pesquisas realizadas no campo artístico e seus reflexos no âmbito educacional, pois são poucos os espaços que, neste momento, se tornaram acessíveis (tanto física como artisticamente) para as pessoas com deficiência.

Além disso, os espaços educativos de dança, em sua maioria, pouco se interessam por transformações nas propostas metodológicas e filosóficas do ensino da dança, os quais se baseiam predominantemente nos aspectos quantitativos da aprendizagem motora. (IANNITELLI, 2004)

Quando enfatizamos na dança contemporânea a singularidade do corpo que dança - seja ele com ou sem deficiência - faz-se necessário que as habilidades técnicas e expressivas se baseiem também na individualidade e não na padronização técnica, para que surjam assinaturas pessoais e uma pluralidade estética.

Em poucos grupos que trabalham com bailarinos com e sem deficiência, os diálogos desses corposmídias na dança têm possibilitado uma construção estética que pode assumir esse caráter transgressor e crítico, apresentando a especificidade de cada corpo dançante e as teias de relações que podem ser criadas e pesquisadas, criando zonas de estranhamento, de encontros e desencontros. As pequenas fissuras, todavia, que começam a ser delineadas, apontam que esses espaços fronteiriços, de uma forma ou de outra, já demarcam uma reconfiguração territorial na dança. Ampliam-se os rastros pelos quais se pode iniciar uma dialogia com a diferença, baseada na alteridade.

\section{NOTAS}

I A metodologia de coleta de dados desse censo foi modificada, sendo incluído nesse levantamento um amplo conceito de deficiência relacionada à capacidade de enxergar, ouvir e caminhar ou subir escadas, com as seguintes alternativas para respostas: incapaz; grande dificuldade permanente; alguma dificuldade permanente; e nenhuma incapacidade. Aliada a essas três questões, uma quarta foi direcionada para a identificação de deficiência física. Desse modo, na perspectiva esboçada para esse censo 
estão inclusos sujeitos que fazem uso de próteses como óculos, bengalas etc., o que fez com que os dados saltassem de $2 \%$ para $14,5 \%$.

2 Lyotard (1993) considera que as metanarrativas são aquelas narrativas totalizantes que marcaram a modernidade tais como: emancipação e progresso da razão, dentre outras.

3 Essa área de pesquisa no Brasil começa a tomar corpo e tem como forte influência a literatura inglesa.

$4 \mathrm{Na}$ Língua Portuguesa, não temos palavras que diferenciem tão claramente, como no inglês, os termos impairment e disability. No Brasil, todos esses termos giram em torno de combinações de palavras com deficiência. Quando nos referimos puramente ao termo deficiência, estamos dando ênfase à palavra impairment, termo este que em português está relacionado à anormalidade e diminuição da capacidade. $O$ termo "pessoa com deficiência" relaciona-se à expressão person with a disability. Ao pé da letra, a palavra disability em português é traduzida como inaptidão ou deficiência. Nota-se que não há uma correspondência direta para esses termos e que a Língua Portuguesa não dá conta das especificidades de termos como disability/disabled.

5 Utilizamos o termo andante a partir da distinção que as pessoas com deficiência física fazem em relação aos cadeirantes (usuários de cadeiras de rodas) e os que usam as pernas para a locomoção.

6 Após a finalização da pesquisa em 2006, a Funarte lançou um edital intitulado Além dos Limites e direcionado "para artistas, grupos e companhias que desenvolvam projetos de pesquisa e criação artística com artistas com deficiência” nas áreas de dança, teatro, música, cujo prêmio contemplou, entre essas três áreas, 15 projetos com um valor bruto de $\mathrm{R} \$ \mathbf{1 7 . 0 0 0 , 0 0}$. A proposta do projeto deveria estar relacionado aos objetivos do Programa Arte sem Barreiras.

7 Grifo nosso.

8 Dados obtidos no folder de divulgação do Programa Arte sem Barreiras, 2003.

9 Termo adotado pelo discurso oficial.

I0 Pela primeira vez na história do Brasil, o governo federal está elaborando diretrizes para as políticas públicas para a dança, com a participação de artistas e especialistas da área, através da instalação da Câmara Setorial de Dança, em 2005, cujos trabaIhos foram finalizados em 201 I, pelo Colegiado Setorial de Dança

I I Depoimento obtido em uma conversa informal com a comissão organizadora, responsável pela seleção dos grupos.

12 Mais questionamentos sobre a relação dançaterapia, dança e corpo do dançarino com deficiência podem ser encontrados na dissertação da autora. (MATOS, 1998)

I 3 Diagnóstico apresentado pelas terapeutas no Manifesto Crepúsculo (2002).

14 Argumentos presentes no Manifesto Crepúsculo (2002) entregue aos participantes do evento após as declarações críticas de Dorival Vieira (arte-educador) em uma oficina. 


\section{EXPLORANDO (RE)CONFIGURAÇÕES TERRITORIAIS E ESTÉTICAS NA DANÇA}

O breve panorama apresentado no capítulo anterior, a partir da análise do Festival Arte sem Barreiras, é representativo de uma configuração da produção do que alguns denominam como dança inclusiva no Brasil. Ao longo da investigação realizamos um mapeamento de grupos que possuem dançarinos com e sem deficiência, efetivando a coleta de dados por meio de formulários enviados a mais de 150 pessoas e/ou instituições', além de dados obtidos através do Programa Arte sem Barreiras e do banco de dados do Rumos Dança (Itaú Cultural, 200I).

Esse mapeamento resultou no registro de 55 grupos espalhados em diferentes regiões do país, sendo que II deles se intitularam como profissionais ou semiprofissionais ${ }^{2}$ e os demais como amadores. Do total dos grupos mapeados, trinta deles estiveram presentes no $1^{\circ}$ Festival Internacional do Arte sem Barreiras, de 2002, o que significa que $55 \%$ desses grupos fizeram parte desse Festival. 
Ao montante geral dos grupos, foi direcionada uma pergunta referente à estética adotada em seu trabalho artístico e/ou esse dado foi recolhido de programas de espetáculos, o que gerou a seguinte situação:

Gráfico I - Categorias dos grupos pesquisados.

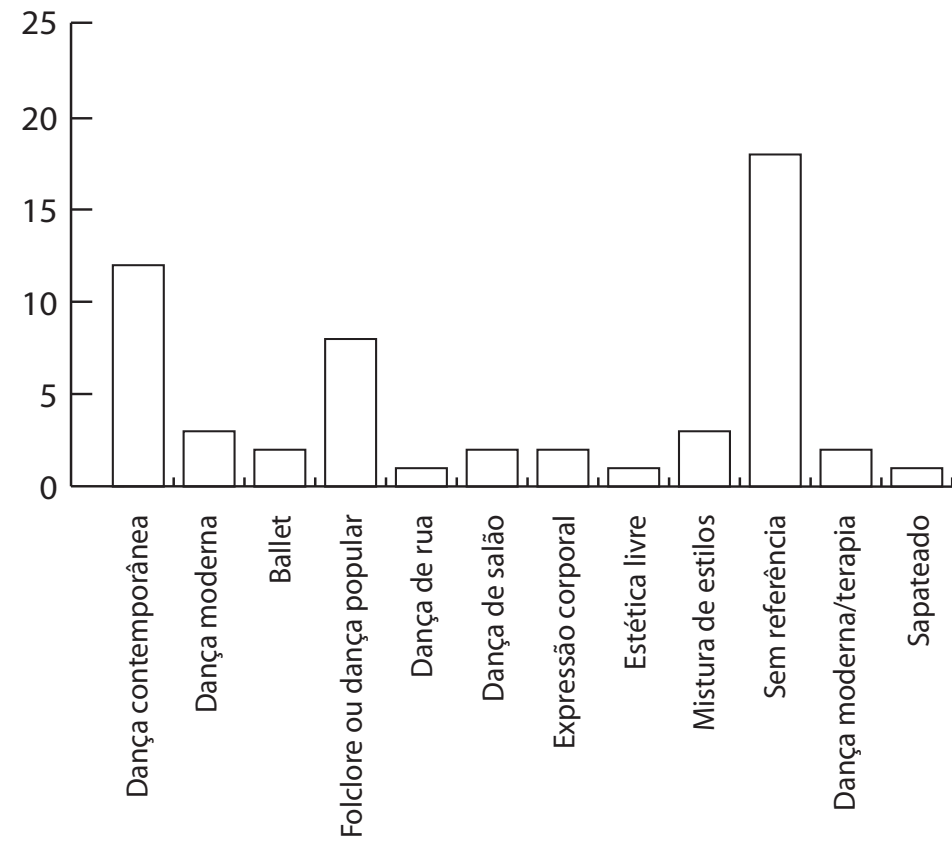

Fonte: Elaboração da autora.

Pelo quadro acima, observa-se que muitos grupos não explicitam o perfil de sua produção artística (32,73\%) e que outra porcentagem representativa (I4,55\%) se define como dança popular. Trabalham com categorias com baixa representação de ocorrência $12,73 \%$, e por esse motivo aqui foram agregadas, como foi o caso do sapateado, da dança de rua, da dança de salão, estética livre e dança expressiva. Apresentam-se 5,45\% deles como uma mistura de estilos e estéticas; outros $5,45 \%$ se identificam como dança moderna; 3,64\% como dança moderna, com cunho terapêutico; e outros 3,64\% como ballet. Do montante geral, 2 I ,82\% apresentam sua produção no âmbito da dança contemporânea. 
No universo dos grupos de dança contemporânea, realizamos uma triagem, a partir de critérios estabelecidos para a pesquisa ${ }^{3}$, na qual selecionamos quatro grupos. Todos os trabalhos desses grupos foram assistidos no Festival Arte sem Barreiras e/ou em apresentações em teatros. Posteriormente, esses trabalhos coreográficos também foram analisados a partir de registros de vídeos e feitas triangulações dos dados com o material das entrevistas presenciais. A análise dos quatro estudos de caso baseou-se em categorias criadas a partir de quatro eixos: (I) proposta artística; (2) processos de criação; (3) produto artístico; e (4) treinamento em dança.

Desse modo, os grupos selecionados que deram conta da tessitura analítica da investigação foram: a Cia. Ekilíbrio, que promove algumas discussões em relação ao ensino da dança; a Limites Cia. de Dança, que abarca questões relacionadas ao treinamento e ao produto artístico em dança para pessoas com deficiência e a Cia. Pulsar e o Grupo X de Improvisação em Dança, que apresentam consistentes produções artísticas.

\section{Cia. de dança Ekilíbrio}

As imagens à seguir fazem parte da coreografia Sente-se, da Cia. Ekilíbrio $^{4}$, com direção coreográfica de Sylvia Renhe. Essa coreografia, com 21 minutos de duração, foi apresentada no lo Festival Internacional Arte sem Barreiras (CONGRESSO, 2002) e em outras cidades do país. A dança se inicia com uma alternância entre 20 focos e blackouts, com lentas mudanças de um quadro para outro, cujas cenas, como os exemplos abaixo ilustrados, mostram diferentes formas de interação com uma cadeira de estrutura metálica, em grupo ou individual, explorando o equilíbrio, pontos de apoio e diferentes formas de sentar e de se relacionar com esse objeto, ressignificando-o. 

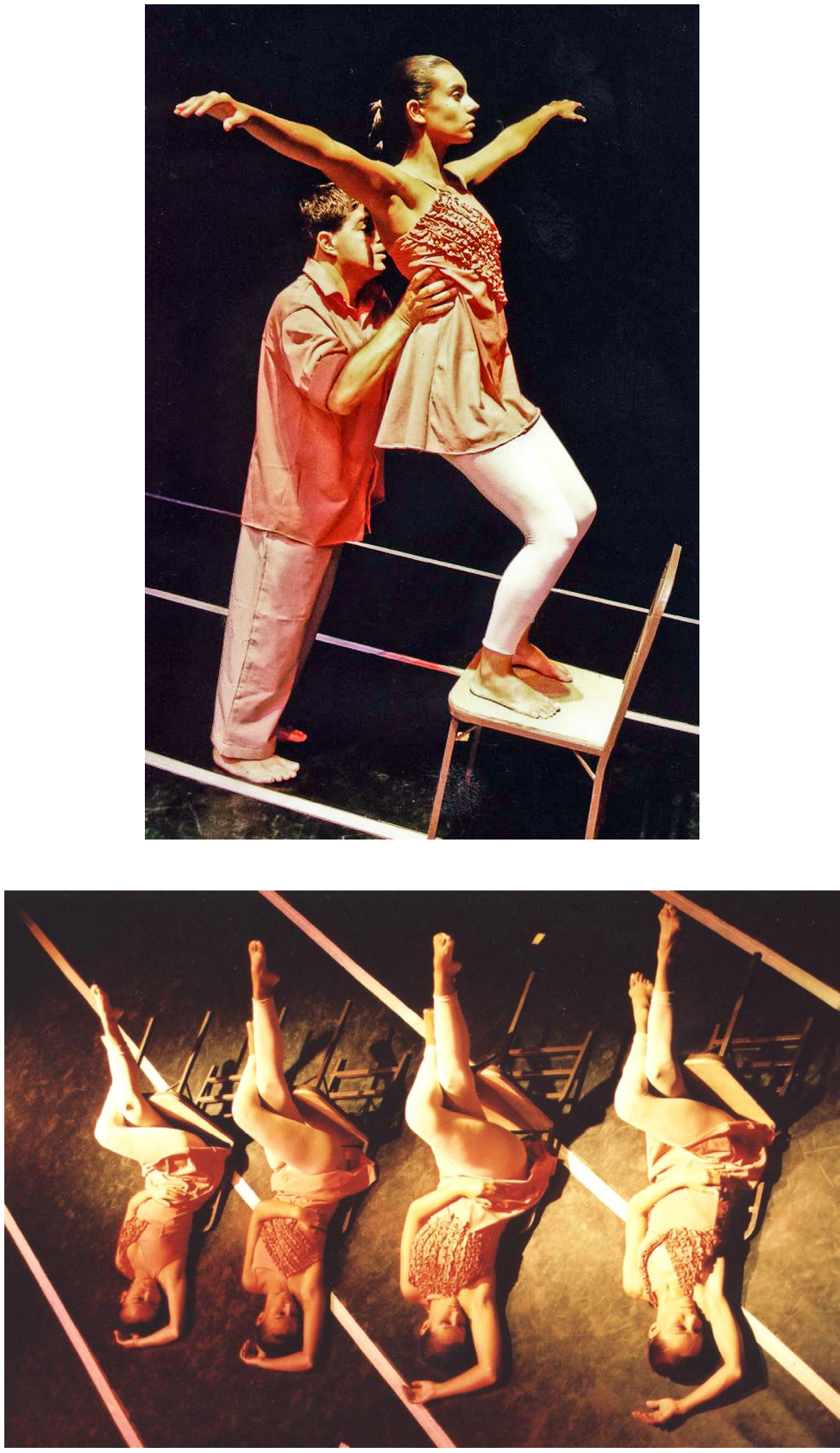

Figuras I e 2. Coreografia: Sente-se (a) e (b). Grupo Ekilíbrio. Foto de divulgação. 
Após o último foco sobre uma cadeira vazia e o blackout, a luz se abre, toca a música ${ }^{5}$ e no palco aparecem quatro dançarinas: uma na frente no lado direito, a segunda na linha da diagonal direita sentada no chão atrás de uma cadeira, a terceira ajoelhada no fundo e uma quarta em pé, de perfil, na frente do lado esquerdo do palco. Entra pela coxia, do lado esquerdo, um dançarino andando vagarosamente em direção a dançarina que está ajoelhada; estes quando se encontram realizam movimentos lentos, que, gradativamente, se conectam e ganham velocidade, explorando a transferência de peso e o equilíbrio no contato com o corpo do outro.

As duas dançarinas localizadas na direita do palco realizam, simultaneamente, diferentes sequências de movimentos em diferentes planos, uma sobre e a outra sob a cadeira. Aos poucos elas também começam a explorar, individualmente, a cadeira para o equilíbrio e transferência de peso. Uma quinta dançarina entra em cena, atravessa o palco e, ao encontrar com a outra que estava localizada do lado esquerdo do palco, explora também o equilíbrio/desequilíbrio, a partir do ponto de contato com o corpo do outro.

Diversas sequências de movimento em duos continuam a acontecer até que ficam apenas três pessoas - duas mulheres e um homem, no palco. $\mathrm{Na}$ mudança da música, entra mais uma dançarina que com um andar acompanhado de movimentos oscilatórios dos braços, se posta na frente do dançarino e com suas mãos sustenta o peso do corpo do outro.

Poderia prosseguir com esta simples descrição da coreografia focalizando as ações e interações que emanam da cena o que certamente poderia gerar na mente do leitor imagens dos tradicionais corpos dançantes. Entretanto, ao lançar um olhar atento, com foco nas singularidades e suas qualidades de movimento, desvela-se a presença nesse grupo de dois alunos-dançarinos ${ }^{6}$ com múltipla deficiência, que, ao assumirem o papel de dançarinos, exploram suas fisicalidades, apresentam suas formas de auto-organização, de adaptação ao meio e criam com os demais membros do grupo estratégias para estarem em cena.

A Cia. Ekilíbrio é o único dos grupos analisados que não está localizado em uma das capitais do Brasil. Nos dados do Rumos Dança (2003) é também o único dentre os grupos investigados que especifica a inclusão de dançari- 
nos com deficiência e esclarece seu papel de dança inclusiva desenvolvendo "uma linguagem própria dentro das noções e construções da dança contemporânea." (RUMOS DANÇA, 2003) Nesse sentido, a inserção desse grupo no campo de análise desta investigação dar-se-á pelo fato do mesmo ser o único dos grupos mapeados que apresenta uma proposta diferenciada na articulação da ação educativa em dança com uma preocupação com a pesquisa artística. Ademais, o grupo não possui dançarinos cadeirantes e a presença dos dois alunos-dançarinos com múltiplas deficiências (mental e sensorial - auditiva e visual) traz indagações sobre quais procedimentos são adotados no treinamento e no processo de criação, no sentido de assegurar uma consciente participação desses alunos na organização coreográfica.

Nesse sentido, buscamos compreender algumas das estratégias utilizadas por esses sujeitos no processo de se tornarem um corpo dançante. Apesar de citarmos, nas próximas páginas, determinadas características presentes nesse tipo de múltipla deficiência, não iremos nos aprofundar nas questões patológicas e nem nas limitações significativas de seu funcionamento adaptativo, como a comunicação e outras habilidades, limitando-nos apenas aos aspectos que se relacionam a este estudo. Assim, o norte a seguir será a singularidade desses sujeitos no processo de criar e dançar visando a perceber suas capacidades de adaptação.

\section{O contexto do grupo}

A ideia de fundar a Ekilíbrio surgiu a partir da conexão de alguns projetos de dança realizados por Christine Sílmor - professora de educação física, bailarina, educadora e coordenadora dos trabalhos do Comitê de Juiz de Fora do Programa Arte sem Barreiras. Em 1996, essa professora atuava em escolas públicas e particulares e teve como meta favorecer um intercâmbio entre seus diferentes alunos, tanto no que se refere ao espaço físico, trazendo os da periferia para a escola do centro e vice-versa, quanto a propiciar a troca de experiências.

Por meio dessas ações, Christine Sílmor percebeu a potencialidade artística de alguns participantes e, desse modo, pensou em viabilizar a profissiona- 
lização, formando, em 1998, a Cia. Ekilíbrio. Inicialmente, o grupo funcionava em locais cedidos para ensaios, como escolas, academias ou clubes, em troca da inserção do nome do apoiador no seu material de divulgação.

Em 2002, essa companhia tornou-se uma associação - Associação Amigos do Ekilíbrio - Dança, Cultura e Cidadania - e, por meio da Lei Municipal de Incentivo à Cultura obteve apoio de empresas da região, o que viabilizou a estruturação de sua sede como um pequeno espaço cultural. Assim, a Ekilíbrio além de oferecer aulas de dança nas quais todas as turmas são inclusivas, tornou-se também um espaço usado para a apresentação de espetáculos de pequeno porte, principalmente os do próprio grupo. Muitas vezes, esse espaço também é usado para a realização de palestras sobre inclusão e cursos na área de dança, tendo, por exemplo, efetivado uma parceria com a Faculdade Angel Vianna (RJ) para um curso de extensão em, 2004.

Até 2006, o grupo, ainda encontrava-se em processo de profissionalização, com um elenco composto por cinco dançarinos sem deficiências: as alunas Raíssa Moraes e Louise Moraes; um dançarino acadêmico de educação física, Ricardo Visciano; Christine Sílmor; e Sylvia Renhe; e dois dançarinos com deficiência: Coriseu Guedes e Cássia Guedes. Todos os alunos-dançarinos tiveram a formação em dança feita dentro da própria Ekilíbrio iniciada quando eram adolescentes.

A entrada de alunos com ou sem deficiência na companhia passa por um processo de seleção baseado em observações de sala de aula. Segundo Christine Sílmor, os que já são adolescentes e "têm um interesse maior na dança, são comprometidos e responsáveis, são convidados a participarem das aulas da companhia. Isso independente de apresentarem alguma deficiência ou não."

Em 2005, os dançarinos participantes do grupo tinham uma média de sete anos de atividades na área, o que implica serem ainda corpos em processo de construção profissional, tanto no treinamento corporal quanto no amadurecimento da expressividade artística. Os dois alunos-dançarinos com múltipla deficiência tinham mais de 40 anos de idade e uma experiência média de seis anos na dança. Eles são irmãos e os dois apresentam a mesma deficiência ${ }^{7}$, com diferentes graus de comprometimentos. Ambos possuem 
uma dificuldade de comunicação, sendo que Cássia Guedes atende a estímulos sonoros enquanto Coriseu Guedes apresenta um resíduo auditivo em apenas um ouvido. Além do mais, Coriseu Guedes possui dificuldades motoras $^{8}$ e uma menor prontidão para o movimento.

É sabido que a deficiência intelectual se caracteriza pelas limitações na capacidade de operar e compreender os dados cognitivamente, o que em sua maioria implica, dentre outros aspectos, inabilidades na comunicação oral (com a existência de um vocabulário restrito e fala linear) e a parcialidade do desenvolvimento de uma auto-suficiência e das habilidades sociais.

Esses aspectos derivam de um nível cognitivo que pode ficar estabelecido, de acordo com as classificações piagetinianas, entre o período sensório-motor (0-2 anos) e o período das operações concretas (7- 12 anos). Entretanto, segundo Bartalotti (200I), apesar de durante um longo período as pessoas portadoras desse transtorno de desenvolvimento terem recebido um treinamento para terem ações determinadas exteriormente à sua consciência individual, hoje, a prática procura favorecer para esses sujeitos uma abordagem qualitativa, buscando promover uma independência, entendida como auto-regulação, e a oportunidade de desenvolver suas habilidades adaptativas no campo social. No caso da dança, essa atividade, enquanto ação artístico-educativa, pode promover um desenvolvimento de habilidades, da percepção sensório-motora, da auto-estima, da comunicação, da consciência corporal e das relações que são estabelecidas entre corpo e ambiente.

A Companhia, até 2006, funcionava com uma rotina de quatro encontros semanais, cada um com quatro horas de duração, sendo que as duas primeiras horas eram destinadas para o treinamento corporal e as duas outras para o processo de criação e ensaios. No que se refere ao preparo técnico, o trabalho era realizado tanto por Christine Sílmor quanto por Sílvia Renhe, esta também graduada em educação física e bailarina formada pela Alvin Ailey American Dance Center (EUA).

Christine Sílmor tem um trabalho mais voltado para a consciência corporal, enquanto Sílvia Renhe ministra aulas de ballet e aulas de dança moderna, 
utilizando como base várias técnicas de dança moderna (Martha Graham, Lester Horton, José Límon e Eric Hawkins), que conheceu em sua formação na Alvin Ailey. Aliado ao trabalho técnico, essa professora utiliza os princípios da dança contemporânea e do contact improvisation, tendo com base experiências tidas em cursos com João Saldanha, Tuca Pinheiro e Tica Lemos.

\section{Processos de criação e suas relações}

\section{com diferentes corpos}

Voltemos à coreografia Sente-se. A primeira parte da coreografia, descrita anteriormente, tem influência de princípios do Contact improvisation - como o uso de transferência de peso e impulso a partir do contato com o outro corpo -, mas podem também ser encontrados alguns padrões de movimento alusivos a técnicas corporais da dança moderna - por exemplo, queda em espiral de Martha Graham - e da composição da dança pós-moderna - simultaneidade, fragmentação, sobreposição e repetição. Ao longo da coreografia, surgem metáforas que exploram sensações e situações abstraídas a partir do objeto cênico, cadeira. Uma dessas metáforas está relacionada com o trecho coreográfico que acontece na terceira música. Três dançarinas estão sentadas em suas cadeiras e essa cena nos remete a flashes de um baile, no qual ocorre a espera, a conquista, o movimento e a dança a dois; só que, aqui, realizados em alguns momentos com a cadeira, e em outros simulando uma relação com um inexistente parceiro da dança. Esse clima é quebrado com a entrada de mais dois dançarinos, Ricardo Visciano e Cássia Guedes, que começam a brincar com as cadeiras que estão no palco, como num jogo de troca de lugares.

É interessante assinalar que em alguns trechos coreográficos nos quais a aluna-dançarina Cássia Guedes atua, pode-se perceber sutis indicações de iniciações de movimentos fornecidos por outros dançarinos, através do impulso do movimento ou de um toque em determinada parte do corpo e em outros momentos um domínio de suas próprias ações, reconhecidos através de seus deslocamentos pelo palco e pela execução de uma pequena 
célula coreográfica individual, que é feita com a cadeira e que reflete suas características pessoais de movimento.

Em muitas ocasiões as sequências de movimentos realizadas por Cássia Guedes se articulam temporalmente com movimentos realizados por outros dançarinos - por exemplo, ela faz um movimento de balanço lateral com a cadeira enquanto uma outra dupla faz o mesmo movimento com o peso do corpo do outro -, ou mesmo, são realizados em sincronia com outros dançarinos, o que nos leva a identificar certa autonomia e a presença de mecanismos organizativos na sua percepção individual e grupal. Sobre esse aspecto Sílvia Renhe (2005) afirma que:

No início realmente era assim, a gente tinha que dar o modelo, tinha que ser até quase que guiado, mas aos poucos eles foram percebendo que eles aprenderam aquilo. Cássia adora mostrar o que ela aprendeu, ela tem agora esse vocabulário, ela criou um vocabulário; ela mostra, ela sabe que ela aprendeu; ela quer mostrar que ela aprendeu, ela quer mostrar que ela sabe fazer o que foi proposto. Mas esse estímulo, pra fazer uma coisa individual, também é recente.

Nas duas músicas seguintes, com características populares, são usadas diferentes sequências de movimentos realizadas em duplas, trios ou em grupo que utilizam impulsos, giros, transferências de peso e rolamentos com e sem a exploração da cadeira. Nessa parte, há uma pequena participação do aluno-dançarino Coriseu Guedes.

Com um olhar mais atento, pode-se observar que há também uma condução de Coriseu Guedes pelo palco, bem como de seus movimentos e que, em outros momentos, há a ativação de uma espécie de "senha" do movimento, onde um dançarino toca, por exemplo, sua cabeça, o ombro e o braço e, após esse toque, ele inicia uma sequência repetitiva de movimentos que envolvem essas partes do corpo. Em poucos momentos, Coriseu Guedes apresenta a iniciativa individual da geração do movimento antes dos demais membros do grupo, diferenciando-se da relativa autonomia de Cássia Guedes.

Na última parte da coreografia, acompanhada da música Stand by me, de King Ben E., amplia-se o sentido lúdico do sentar e, analogicamente, o palco 
torna-se nessa cena um enorme playground onde diferentes corpos, com diferentes idades e referenciais de movimento, enfatizam o brincar com a cadeira ou a relação com o corpo do outro.

A segunda coreografia, Sem nome (2003), surgiu em decorrência de pesquisas iniciadas em um workshop realizado com a CandoCo Dance Company (Inglaterra). Em 2002, a Ekilíbrio, em parceria com Fundação Cultural Alfredo Ferreira Lage (Funalfa), levou para Juiz de Fora a CandoCo para realizar um workshop de cinco dias e uma apresentação das coreografias que integravam sua turnê 2002-2003, apresentando o mesmo repertório que fez parte do $1^{\circ}$ Festival Internacional Arte sem Barreiras.

O resultado da experiência do workshop ${ }^{9}$ com a CandoCo, que em uma das atividades explorou células individuais de movimento relacionadas ao nome de cada participante, tornou-se o elemento gerador para uma nova criação. Os dançarinos da Ekilíbrio, com a direção coreográfica de Silvia Renhe, criaram a coreografia Sem nome, na qual buscam abordar a afirmação da singularidade de cada ser e discutir aspectos das identidades pessoais e sociais.

De uma forma geral, o resultado da coreografia Sem nome não atinge plenamente os objetivos propostos (tanto artísticos, quanto temáticos) e poderia ser mais bem editada no que se refere ao timing.

Ela é iniciada com um movimentar-se individual, porém simultâneo, dos dançarinos no palco. Durante as caminhadas, frases, muitas vezes incompreensíveis, são ditas e direcionadas a um(a) outro(a) dançarino(a) e normalmente as respostas são evasivas. Todos sentam em fileira, um ao lado do outro; começa uma música tendo ao fundo o usual ruído feito no estabelecimento de uma conexão discada de internet. Os movimentos são individualizados e a cada execução de uma célula individual é criada uma vinculação para a ativação do movimento do outro, de forma sequencial. Esses movimentos de passagem vão e voltam até que a rede é ampliada e os corpos se espalham pelo palco por meio de movimentos de giros e deslocamentos no chão. 

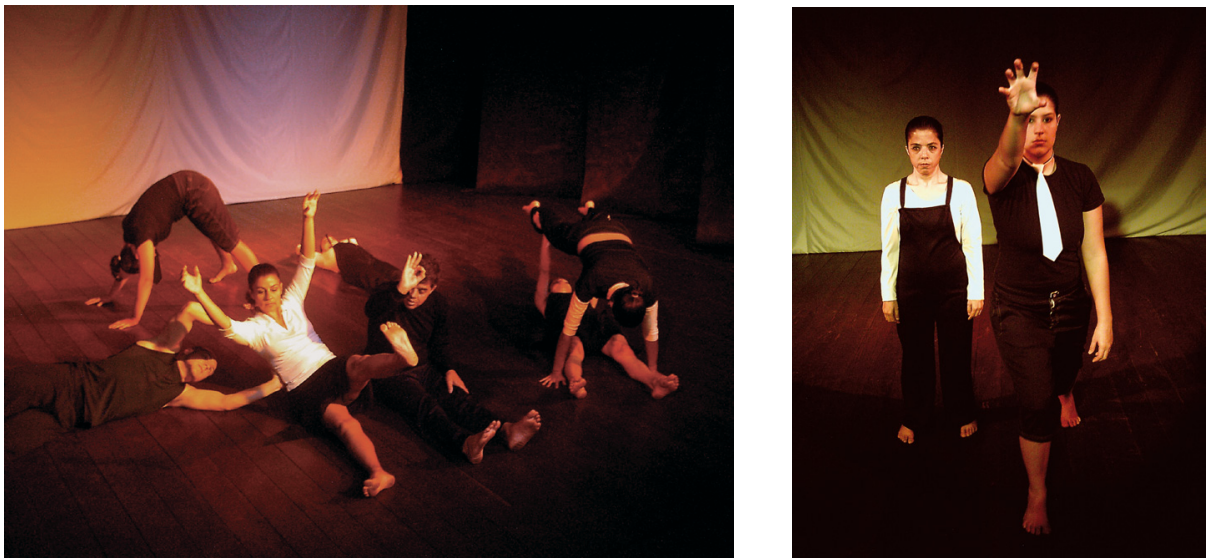

Figuras 3 e 4. Coreografia: Sem nome (a) e (b). Grupo Ekilíbrio. Fotos de divulgação.

Os dançarinos voltam a andar e, em alguns momentos, dois corpos se encontram e se tocam com rápidos contatos e quedas, enquanto outros continuam a se locomover pelo espaço. Há a presença de células individuais que se repetem aludindo a um símbolo de identidade pessoal.

Apesar de haver poucas conexões entre eles, em determinado momento a dançarina Raíssa Moraes, ao repetir a sua sequência de movimentos, grita a palavra "caindo" e vagarosamente desequilibra seu corpo na direção do chão; todos correm ao seu encontro e pegam seu corpo, balançam-no no ar e restabelecem a sua conexão.

Em outras partes da coreografia, além da exploração das sequências individuais realizadas em outros planos com a ampliação e redução de movimentos, pode-se perceber a contaminação da sequência de movimentos: um dançarino, na sua sequência, incorpora partes da célula coreográfica do(a) outro(a) dançarino(a), modificando a si próprio(a). No final, cada um executa sua sequência de movimentos alternada com uma segunda versão, onde se misturam elementos de seus movimentos com o dos outros, o que sugere a contaminação que o ambiente e o outro produziu no corpo. $\mathrm{Na}$ última cena, a dançarina Raíssa Moraes repete o movimento de desequilíbrio em direção ao solo, grita “caindo”, mas, ninguém vai ao seu encontro. Quebra-se a conectividade e os corpos se dissipam. 
Alguns aspectos do processo e dos produtos coreográficos de Sentese e de Sem nome precisam ser discutidos. Segundo depoimento de Sylvia Renhe, os trabalhos coreográficos da Ekilíbrio partem de pesquisas laboratoriais nas quais todos os alunos-dançarinos participam. Para essa coreógrafa, seu processo de criação é intuitivo e está ancorado nas possibilidades de movimentos do elenco, a partir de alguns estímulos fornecidos (verbais, imagéticos ou de movimentos) e dos materiais que surgem das improvisações, seguido de uma organização coreográfica.

Em Sente-se, especificamente, o processo de criação incorporou alguns movimentos resultantes de brincadeiras realizadas no intervalo ou durante o trabalho de investigação e uma poesia escrita pelo dançarino Ricardo Visciano, cujas palavras-chave foram geradoras de improvisações que resultaram em um jogo coreográfico.

Por abordar aspectos abstratos da relação com o objeto cênico cadeira - que vão além da sua funcionalidade - indaguei, na entrevista realizada com o grupo, como os alunos-dançarinos com múltipla deficiência são inseridos nesse processo. Foi consenso no grupo a pouca eficiência do uso de estímulos verbais, principalmente no caso de Coriseu Guedes, e que as meIhores respostas foram obtidas por meio de estímulos corporais, já que há muitas dúvidas sobre os níveis de comprometimento funcional adaptativo, de compreensão intelectual e de habilidades de comunicação desses alunos.

A falta de uma comunicação verbal ou gestual também foi por nós presenciada. Na entrevista, Coriseu Guedes não apresentou respostas às nossas perguntas, nem mesmo sobre sua identificação pessoal, o que dificultou a coleta de dados uma interação. Já, Cássia Guedes, durante a entrevista, comunicou-se oralmente, mas, não construiu frases da maneira convencional; ela sabia se identificar, explicitou seu gosto pela dança e narrou de forma bem fragmentada suas ações em pequenas partes da coreografia, enfatizando com quem ela realizava os movimentos.

Em algumas partes da entrevista, Cássia Guedes respondeu questões por meio de monossílabos que nem sempre estavam relacionados às perguntas realizadas ou refletiam uma opinião pessoal. $\mathrm{Na}$ entrevista grupal, feita em julho de 2005, D. Catharina, mãe de Cássia e Coriseu, salientou que Cássia 
na escola consegue escrever o próprio nome e copiar as letras, mas não lê e em casa ajuda nas atividades domésticas. Quanto a Coriseu, a mãe ressalta que ele é uma pessoa tímida, com dificuldades motoras, mas que em casa conversa, atende telefone, faz tarefas cotidianas, mas, apesar de continuar a frequentar a escola especial, não conseguiu ser alfabetizado. As dificuldades de comunicação e compreensão desses alunos-dançarinos se refletem em diferentes aspectos do processo de ensino-aprendizagem e na criação, podendo haver a necessidade de um direcionamento maior de suas ações:

Isso é o que é mais difícil de tudo. É o que sempre me deixou mais frustrada, porque eu tinha a vontade assim de não estar guiando, de não estar mandando fazer dessa ou daquela forma, mas de estar realmente vendo o que eles tinham para oferecer. Então, algumas vezes, isso dá certo. A gente estimula e eles dão respostas. Eles estão progredindo e isso está acontecendo mais agora, mas no início já foi mais comandado. No 'Sente-se' Cássia fez a improvisação na cadeira também; já o Coriseu não estava no processo ainda no início, só no final que ele entrou, e ele entrou, apesar de guiado, mas a gente estava com ele, fazendo aquilo que ele poderia fazer [...]. Não foi o estímulo verbal, mas foi o estímulo de movimento assim, pelo toque e a gente vai sendo guiado pelo que eles podem fazer também. Já [Cássia] já deu essa resposta com a cadeira [...], ela improvisou com a cadeira e depois eu só 'enxuguei' [...]. Eles têm uma memória fantástica.

Com o Coriseu é mais difícil de estar argumentando assim, falando, verbalmente. Com Cássia é mais fácil, dela entender o que você está querendo, propondo, com o Coriseu já é mais pelo movimento [...]. (Renhe, 2005)

Apesar de ser ressaltada essa sensação de frustração pela necessidade de um maior direcionamento dos alunos-dançarinos com deficiência durante o processo, em outros momentos, as respostas às propostas atingem resultados inesperados:

O estímulo acontece de acordo com a necessidade. Isso é para todos. Pode ser através do corpo, da fala, do visual, do imaginário. Cada um entende e responde de forma diferenciada ou não. Isso é muito complexo. Às vezes em um laboratório, é dado um estímulo, no qual é esperada uma resposta, e essa resposta vem tão diferente do esperado, mas ela é tão rica, talvez muito mais rica do que nossa imaginação pudesse elaborar, e daí acontecem outras coisas. É difícil explicar, mas o trabalho coreográfico 
acontece assim. Os bailarinos são sempre estimulados a produzirem, e às vezes observamos Cássia e Coriseu fazendo coisas que imaginávamos que seriam impossíveis para eles. (Sílmor, 2005).

Essas respostas corporais revelam a ocorrência de construções pessoais que envolvem percepções cinestésicas e proprioceptivas desses alunos, mas que também desvelam algumas dificuldades na percepção e/ou assimilação do movimento,

A Cássia também, ela quer mais o movimento, ela busca mais o movimento [...]. O Coriseu ele é mais parado, ele gosta de ficar mais parado [...], ele tem uma dificuldade motora. (Sílmor, 2005)

Às vezes a gente muda alguma coisa e a gente tenta manter assim, o que eles fazem pra não perder. A gente não pode também mudar [...] o movimento totalmente. A gente tem que deixar parecido pra que não perca aquela referência [...], mas tem coisas que eles têm que pegar [como por exemplo], tem que andar para tal coxia [...], tem que aprender ali na hora a fazer isso. (Visciano, 2005)

Em estudos na área da Psicomotricidade, Meyer (1988) sinaliza que temos uma memória somoestésica, formada a partir de informações recebidas pelas vias cinestésicas, que definem as características espaço-temporais da trajetória do movimento, e as informações estatésicas, que nos dão a percepção do posicionamento dos segmentos corporais na referência postural. Para esse autor, essa memória nos possibilita termos uma linguagem gestual, independente de uma linguagem verbal, fazendo com que a "linguagem mimo-posturo-gestual provoque uma grande subversão das concepções lingüísticas do pensamento." (MEYER, 1988, p. 90)

Hoje, com as contribuições advindas das neurociências, sabe-se que o sistema sômato-sensitivo é uma combinação de diferentes subsistemas, que transmitem ao cérebro sinais sobre os estados corporais, por meio dos sistemas proprioceptivo ou cinestésico, o tato discriminativo, as sensações interoceptivas e os estados músculo-esqueléticos. 
Assim, a experiência perceptiva é o suporte para o estabelecimento de um processo contínuo de auto-categorização conceitual. (GREINER, 2005) Esse processo parece estar presente nas respostas corporais feitas pelos alunos com deficiência.

A busca pelas qualidades expressivas do movimento de cada dançarino e as construções que são esboçadas a partir da singularidade de cada corpo vai ao encontro da abordagem das inteligências múltiplas de Howard Gardner (1995), o qual sugere que as habilidades cognitivas se processam de formas diferenciadas, ${ }^{10}$ sendo uma delas a inteligência cinestésica.

Para lannitelli (2004), a inteligência cinestésica permite considerar as singularidades efetivadas no corpo que dança por meio de suas percepções, formas de processamento e idiossincrasias. Esse aparenta ser um dos caminhos utilizados para a efetiva participação dos alunos Coriseu e Cássia no processo de criação, o que coloca as diferentes paisagens do corpo no foco da investigação.

A múltipla deficiência também traz comprometimento na consciência de si próprio e de sua relação com o ambiente. Como ressalta Sílvia Renhe (2005), há diferenças nessa percepção em cada um dos alunos:

Eles têm a referência mais do movimento no corpo deles, e não exatamente se ali é frente ou se é aqui atrás [...]; eu ainda não sei como exatamente eles trabalham. Quando a gente corrige o Coriseu, por exemplo, pra ele é simplesmente a mudança do corpo dele; eu não sei se ele sabe que está mudando em relação ao espaço [...]; não tenho certeza, [...], é muito obscuro isso pra mim ainda.

Hoje, Cássia já arruma a cadeira, ela sabe que a cadeira está torta, ela arruma a cadeira com relação à frente do palco, à plateia. Então isso eu já percebi nela assim, recentemente [...]. Ela não fazia isso, a cadeira ficava torta e torta ficava até o final do espetáculo então, não tinha essa referência de espaço, tinha a referência dela com relação à cadeira.

Por essas razões, a diretora e a coreógrafa, com a ajuda do grupo, acabam buscando estratégias alternativas para que eles possam se localizar espacialmente, como no momento de uma apresentação: 
A gente sempre busca uma referência [...]. lá na PUC [...] o palco era assim estreito e comprido. Lá no fundo, a gente deixou uma luz acesa, arrumou o esquema duma luz [...] porque aí eles tinham que andar na direção daquela luz, e era isso. Esse era o código (Sílmor, 2005).

Outro aspecto que interfere no processo como um todo se refere a pouca autonomia desses dois alunos no grupo, criando interdependências:

A gente fica mais seguro a partir do momento que você sabe, mais ou menos, entre aspas, o que está fazendo. Acho que a Cássia já atingiu isso, ela tem muita noção do que ela faz. Ela tem essa possibilidade já de estar sozinha [...], ela dança no centro, sozinha. O Coriseu, acho que ele ainda não chegou muito nisso também; ele está meio inseguro, como ele tem um pouco de dificuldade de criar alguma coisa sozinho. (Moraes, 2005)

O Coriseu é mais parado; ele gosta de ficar mais parado. Assim, toda hora tem que estar lembrando que ele tem que estar movimentando, e [para isso] tem a colaboração de todos os bailarinos. (Sílmor, 2005)

Cássia tem a dificuldade visual, a dificuldade auditiva, e ela está deitada com a cabeça para o chão sem ver nada [referindo-se a um trecho da coreografia]. Então, se ela não escutar, ela perde o tempo, aí tem esse momento que acontece esse toque que ela sabe que tem que ir. (Sílmor, 2005)

Como eles não ouvem e não enxergam, eles precisam estar muito atentos, porque eles pegam o que dá pra pegar. Quando a gente muda de palco, quando muda de espaço assim, eles estão sempre atentos e a gente precisa ficar atento realmente, [...] porque podem acontecer acidentes, como já aconteceu. Uma vez [Coriseu] quase caiu do palco e na pontinha eu o segurei. Estava todo mundo deitado e Coriseu andando sozinho no palco [...] aí eu levantei correndo e segurei; ele ia cair de verdade [...]. (Moraes, 2005)

O sexto aspecto refere-se à compreensão da temática da coreografia. Em Sente-se, apesar de haver um nível de abstração, o objeto cadeira facilitava a criação de metáforas e outros significados para os alunos-dançarinos. Já em Sem nome, a temática eleita para essa coreografia requer um nível mais eleva- 
do de abstração de pensamento para a compreensão da sua proposta, o que dificilmente é alcançada pelos dançarinos com deficiência e, em alguns momentos, essas dificuldades também encontram eco naqueles sem deficiência.

Ao referirmos, na entrevista, sobre a percepção de si próprio, através da pergunta "quem é você?", os dois alunos com deficiência não responderam a esse estímulo e D. Catharina (2005), mãe desses alunos, coloca que

Eles aprendem o que é falado, mas eles não têm consciência da fala. Tanto é que na pergunta [feita no decorrer da coreografia Sem nome] quando perguntam pra ela, Cássia, o seu nome, ela fala camisa, porque tem uma história de uma camisa também [...].

Por outro lado, em alguns depoimentos dos dançarinos sem deficiência, também emergiu a dificuldade da abordagem temática dessa coreografia. Como coloca Ricardo Visciano: "identidade é uma coisa que nem a gente sabe, às vezes, é uma coisa assim que [...] eu ficava totalmente doido".

Outro aspecto a ser observado na coreografia Sem Nome refere-se à presença de toques sutis que impulsionam a execução de movimentos, a mesma ocorrência já citada na coreografia Sente-se.

No caso de Coriseu Guedes, pode-se exemplificar com toques em um ombro, que geram o impulso de um balanço no chão; conduções pelo espaço ou um leve toque no pé, que desencadeia uma célula de movimento. Diferentemente da primeira coreografia, em que esse aluno começou a participar já no final do processo de criação, o que se torna mais um elemento dificultador, nesta há uma relativa autonomia e consciência nas interações com o outro, através de carregas ou movimentos realizados concomitantemente com outra dançarina. Já, Cássia Guedes apresenta um maior domínio do movimento e percepção espaço-temporal.

É interesse ressaltar que as peculiaridades do movimento desses alunos-dançarinos com deficiência - como um andar com oscilações laterais de peso, hipotonia, balanço de braços, maior uso do peso nos membros inferiores - não são camuflados na coreografia, mas, também, não são explorados como elementos geradores de pesquisa de movimentos. 
Mesmo com uma ampliação de seus referenciais de movimento, algumas dificuldades encontradas no processo de assimilação da proposta por parte desses alunos são enfatizadas por Sílvia Renhe (2005):

A gente passou pra Cássia a questão do nome, dela escrever o nome dela com a movimentação dela, ela conseguiu entender. O Coriseu não conseguiu [...], mas ela sabia que no final das contas a gente fazia 'escreve seu nome', aí ela fazia a movimentação, a que era referente ao nome dela. E ela sabia também que ela tinha que entrar e repetir aquela movimentação; quando ela entrasse, naquele momento, ia esbarrar comigo, eu iria fazer a minha movimentação e ela a dela. Mas aí tem aquele processo deles memorizarem e repetirem. É mais técnico, mais movimento [...].

Durante a entrevista, ao abordar as especificidades do processo de criação de cada uma dessas coreografias, ficou explícito que o processo de Sem nome foi mais complicado, tanto para os alunos-dançarinos, quanto para a coreógrafa:

Eu queria falar do processo de criação [de Sem nome] que foi muito diferente de 'Sentese". Sente-se' foi tão gostosinho assim, o processo de criação, tudo girava em volta da cadeira e etc., foi ótimo. Agora o 'Sem nome', foi assim, acho que foi ruim pra todo mundo né, digamos, tinha que sair, mas não saía. A gente demorou muito tempo pra criar [...], o 'negócio' não vinha, a gente não conseguia tirar aquilo e passar [...]. (Moraes, 2005)

No 'Sente-se', esses movimentos, eles foram surgindo mais naturalmente assim, pela própria proposta lá da cadeira, da poesia [...]. Já o Sem nome eu acho que ele foi uma coisa mais imposta, ele foi imposto, realmente, já tinha o trabalho [...] [referindo-se as células de movimento surgidas no workshop do CandoCo]. Quando se fala em identidade, foi o que a gente conseguiu trazer para aquela situação que a gente estava vivendo. Mas não foi uma coisa muito confortável assim, ninguém estava se sentindo muito confortável com isso. (Renhe, 2005)

[...] ficou mais difícil por ser uma coisa mais abstrata. Assim, o próprio processo mais técnico [...], assim de ter mais referência na música, de contagem [...], se você não ir ali, o outro cai no chão. (Visciano, 2005) 
Eu lembro do dia, o dia que a gente terminou o 'Sente-se' [... . . Do Sem nome eu não me lembro não, mas foi um alívio o dia que a gente terminou. (Moraes, 2005).

Muitas das questões aqui levantadas - principalmente aquelas relacionadas aos dançarinos com deficiência intelectual - remetem ao nó crítico da consciência. Teorias contemporâneas, principalmente aquelas advindas das neurociências, têm trazido importantes contribuições para o entendimento do funcionamento da mente e, dentre elas, os estudos de Antônio Damásio (2000) dão indícios de que a consciência é inseparável da emoção e a emoção é inseparável de um estado do corpo. Por outra via, estudos como os da comunicação e da consciência corporal sugerem que pensamos com o corpo (KATZ, 1994) e que a consciência exerce um papel fundamental nesse processo.

Damásio (2000) define consciência como um termo abrangente usado para designar fenômenos mentais que permitem nos colocarmos como observadores ou conhecedores das coisas observadas e proprietários dos pensamentos formados em nossa perspectiva, o que nos torna agentes no processo de conhecer. Além disso, a consciência, para Damásio, é como um rito de iniciação que

Permite a um organismo equipado com a capacidade de regular seu metabolismo, com reflexos inatos e com a forma de aprendizado conhecida como condicionamento tornar-se um organismo com mente, o tipo de organismo em que as reações são moldadas por um interesse mental pela vida do próprio organismo. (Damásio, 2000, p. 44-45)

A consciência, na perspectiva damasiana, refere-se às relações que são estabelecidas no processo de "conhecimento de qualquer objeto ou [na] ação atribuída a um self” (DAMÁSIO, 2000, p. 47) e não deve ser explicada apenas em termos de suas funções cognitivas como, por exemplo, linguagem ou memória, pois temos dois tipos de consciência: a central, que não requer, por exemplo, as funções acima citadas, pois ela funciona no "aqui e agora" e seu senso interior é baseado em imagens; e a consciência ampliada, que pode ter diferentes níveis e, para a efetivação de seus mais complexos 
graus, a linguagem é necessária. È importante salientar que Damásio (2000) explana que consciência ampliada não é a mesma coisa que inteligência. A consciência ampliada é um pré-requisito para a inteligência, pois, a primeira torna o organismo ciente do conhecimento e a inteligência é a capacidade de manipular conhecimentos com êxito. Em sua perspectiva, "os seres humanos devem à linguagem importantes capacidades, mas a consciência não é uma delas." (DAMÁSIO, 2000, p. 149) Reiterando esse ponto de vista, Damásio ressalta, em uma entrevista, que "mesmo assim estou convencido de que há seres não humanos com consciência alargada que não têm qualquer linguagem e que organizam a consciência de uma forma não verbal." (DAMÁSIO 2000 apud MURCHO, 2005)

Damásio, em sua investigação, enfatiza ter estudado pacientes com deficiências de raciocínio e planejamento e esses apresentavam "a consciência central perfeitamente normal, embora no momento os níveis superiores da consciência ampliada estejam comprometidos." (DAMÁSIO, 2000, p. 162)

Nesse sentido, no caso desses alunos-dançarinos com múltipla deficiência, quando sinalizamos a ausência de respostas verbais e a presença de determinadas respostas corporais, nem sempre automatizadas, pode-se perceber a presença de uma memória corporal e um certo estado de consciência. Porém, como não especialista dessa área, não temos a competência para avaliar seu alcance.

No que se refere ao trabalho coreográfico e à estética do grupo pode-se perceber - muito mais na coreografia Sem nome do que em Sente-se - uma forte influência da ambiência contemporânea da dança e do contact improvisation, no que se refere à fragmentação do movimento, exploração dos fatores de movimento e o uso do peso, impulso, momentum, ação e reação.

De um modo geral, os movimentos na coreografia exploram a velocidade, o que dificulta a plena execução por parte dos alunos-dançarinos. Entretanto, fica notório que, por enquanto, a ênfase dada ao preparo corporal - destacando-se o aprendizado de diferentes estilos de técnicas da dança moderna, aliado à imaturidade da expressividade cênica da maioria dos alunos-dançarinos - dificulta a incorporação das qualidades complexas de 
movimento propostas nessa coreografia, já que ficam em déficit uma consciente exploração de aspectos como relações físicas, quedas, força, relaxamento, velocidade, energia, sensações internas e percepção do movimento. A falta de uma consciente percepção desses aspectos promove na coreografia uma descompensação entre a qualidade de execução dos três dançarinos profissionais e a visível dificuldade presente nos corpos dos alunos.

Nesse sentido, no processo de ensino-aprendizagem, por mais que se transmitam os princípios organizadores do contact improvisation, a resposta corporal depende muito da experiência de cada dançarino e de suas formas de construção do pensamento no corpo. Assim, como já foi ressaltado, eles ainda são corpos em processo de construção para a profissionalização em dança.

Além disso, a temática proposta para essa coreografia, a identidade, requer um grau de consciência ampliada com a participação de um self autobiográfico (DAMÁSIO, 2000), que, baseada nas experiências individuais, permite reflexões que partem da(s) identidade(s), isto é, da noção de singularidade, diferença e de multireferências.

A proposta inclusiva da Ekilíbrio, ao abarcar as diferenças de corpos e capacidades individuais de relacionar-se com o ambiente, apresenta possibilidades e limites para a sua própria produção artística. Por outro lado, sua preocupação com o processo/produto coreográfico traz para o cenário da dança, enquanto uma ação artístico-educativa, uma proposta diferenciada, que, na seriedade de seu trabalho, busca encontrar caminhos alternativos, distanciando-se dos objetivos terapêuticos, os quais normalmente são dirigidos aos sujeitos com deficiência intelectual.

\section{Limites Companhia de Dança}

Sediada em Curitiba, esta companhia foi criada, em 1992, pela bailarina, fisioterapeuta, coreógrafa e professora da Faculdade de Artes do Paraná, Andréa Sério, a partir de seu interesse na diversidade corporal como objeto de investigação no contexto da dança contemporânea, quando ainda era estudante da licenciatura em dança. Em 2005, ela era representante paranaense do Programa Artes sem Barreiras - Funarte. 
Inicialmente, a Limites" foi formada por quatro pessoas com deficiência e aos poucos foi incorporando dançarinos sem deficiência, sendo, em 2005, composta por dez bailarinos, ${ }^{12}$ quatro com deficiência física (paraplegia) e seis sem deficiências, com uma faixa etária que varia dos 19 aos 46 anos. Desde 1992 o elenco teve várias modificações, permanecendo apenas Cláudia Fantin como bailarina da formação inicial. Em 2005, a Limites já possuía outros bailarinos com cinco ou seis anos de atuação no grupo.

No período da coleta de dados, a Cia. Limites contava com o suporte da Associação dos Deficientes Físicos do Paraná, que arcava com o contrato do professor de dança, Gustavo Lutke, e o da coreógrafa e diretora do grupo, Andréa Sério. Outro importante subsídio existente nesse período, cujo apoio foi iniciado em 1998, refere-se ao apoio do Centro Cultural Teatro Guaíra, através do uso de suas dependências físicas para os ensaios e o suporte técnico para as montagens (sonoplastia, iluminação e figurino).

A entrada desse grupo num ambiente tradicional de dança, como o Guaíra, torna-se um exemplo positivo para a abertura de espaços até então negados para pessoas com deficiência, ao mesmo tempo em que mostra um reconhecimento da qualidade artística dessa companhia. Contribuindo para esse cenário inovador, a Limites tornou-se um espaço de pesquisa e de reflexão sobre a prática em dança, já que, desde 1998, tem recebido estagiários dos cursos superiores de dança do Estado do Paraná, tendo incorporado em suas atividades um grupo de estudos em funcionamento desde 2004.

Essa companhia já realizou mais de 100 apresentações em várias cidades brasileiras, tendo participado de festivais do circuito tradicional de dança, como Joinville, em congressos relacionados à educação especial/inclusão, em eventos segmentados como as Mostras do Very Special Arts, em cidades como Brasília, Ponta Grossa, Rio de Janeiro, São Paulo, Belo Horizonte e no exterior (Boston e Los Angeles - USA; e Ismir - Turquia).

Em 2005, o grupo Limites participou da Mostra Arte, Diversidade e Inclusão Sociocultural, promovida pelo Centro Cultural Banco do Brasil, no Rio de Janeiro. Mesmo com essa contínua produção, eles se apresentam como um grupo que tem uma dedicação profissional, mas, que ainda não 
consegue sobreviver dessa atividade, o que faz com que seus componentes tenham atividades profissionais paralelas.

Seus espetáculos costumam ser denominados "Limites em movimento", sendo o mesmo composto por coreografias curtas, podendo ocorrer mudanças no repertório de uma apresentação para a outra. A escolha por esse título é justificada como uma proposta de "mover o espectador para o dinamismo característico da dança contemporânea” (LIMITES, 2005). As coreografias apresentadas são bem distintas, representativas de diferentes momentos da companhia e, segundo sua diretora, transitam do expressionismo alemão até a pós-modernidade, na intenção de retratar a principal característica do grupo: a diversidade.

O espetáculo analisado na pesquisa tinha 35 minutos de duração e era composto das seguintes coreografias: Clap sobre rodas (1992), um duo, com duração média de três minutos; Natura (1995, primeira versão; 2002, segunda versão), duo com Paulo Bravo e Luciana Gomes, com seis minutos; Passagens (1993), duo com Cláudia Fantin e Gustavo Lutke, com seis minutos; In sono (2000), quarteto, com oito minutos de duração; Caçador de mim (200 I), solo de Gustavo Lutke, com sei minutos; e Cores do silêncio (1998, primeira versão; 2002, segunda versão), trabalho em grupo, com sete minutos. Não fizeram parte desse repertório analisado as coreografias Sala de espera (1998) e Disforme (2002), que foram apresentadas no I’ Festival Internacional Arte sem Barreiras. (CONGRESSO, 2002)

Limites se define com um grupo que tem como proposta a pesquisa de movimento na dança contemporânea, visando a novas possibilidades de comunicação do corpo. Assim, em suas criações, a coreógrafa do grupo não concebe a cadeira de rodas como uma extensão do corpo, mas como um meio de locomoção que só é utilizado nas coreografias quando esse se torna um elemento cênico.

Andréa Sério defende a ideia de que, para o dançarino com deficiência, "a roda não é o seu corpo e nem extensão do seu corpo [...]; [na] concepção do corpo de um bailarino, o seu corpo é o seu corpo, a roda é só um elemento, que poderia ser outro". Os bailarinos cadeirantes Cláudia Fantin e Paulo Bravo 
concordam com esse ponto de vista e ressaltam que a cadeira é apenas o meio de locomoção. Em suas palavras:

Cadeira para mim é apenas um instrumento de locomoção, um meio de transporte. De maneira nenhuma é uma extensão de meu corpo. Mesmo que eu não tivesse as pernas jamais a cadeira iria substituir parte do meu corpo. Para mim, que tenho formação em educação física, onde a vida toda trabalhei com esquema corporal, é muito claro separar e saber onde acaba a cadeira e começa o meu corpo. $O$ comprometimento motor não me faz perder, de forma alguma, a noção de corpo como um todo. (Bravo, 2005)

Não entendo a cadeira de rodas como extensão do meu corpo de maneira alguma. Nem no dia-a-dia, nem no processo de criação artística. No dia-a-dia, para mim, é como um meio de locomoção. No processo de criação artística é mais um elemento coreográfico e, como tal, pode estar ou não presente, dependendo da ideia e concepção coreográfica. (Fantin, 2005)

É importante salientar que esses bailarinos tornaram-se cadeirantes em decorrência de acidentes, o que deixa ativa em sua memória corporal os registros de já terem sido pessoas andantes, e esse pode ser um aspecto que os diferencia, por exemplo, da perspectiva do dançarino Edu Oliveira, do Grupo X, cujas sequelas da poliomelite o colocaram desde pequeno na cadeira de rodas. Para este, a cadeira é extensão do seu corpo.

É com ela que minha vida é facilitada. Sempre questiono as pessoas que não têm um cuidado ao lidar com a cadeira comparando-a com partes do corpo do outro. Ou as pessoas que utilizam a cadeira como suporte para seus objetos, porque é a mesma coisa que eu pendurar minhas bolsas, casacos ou qualquer outra coisa nos ombros de quem está ao meu lado. Inclusive, isso, é uma coisa que me irrita profundamente, pois raramente há quem respeite essa questão. (Oliveira, 2005)

Os bailarinos com deficiência da Limites não possuíam nenhuma experiência com a dança antes de entrarem para o grupo; a formação foi feita no processo de fazer/conhecer/apreciar a dança. Apenas Paulo Bravo possuía referências de atividades corporais, tendo sido atleta e professor de educa- 
ção física, no ensino superior, atividade esta que continuou a exercer depois do acidente. Os demais bailarinos sem deficiência possuíam, em sua maioria, graduação em dança, com formação mais direcionada para o clássico, moderno e contemporâneo.

No que se refere à rotina de trabalho, o grupo mantinha uma frequência de cinco encontros semanais, sendo três dias dedicados ao treinamento corporal e a pesquisa de movimentos e os outros dois para a manutenção do repertório. É interessante ressaltar que o grupo destaca a existência de uma pesquisa para o preparo técnico dos dançarinos, que não tem necessariamente uma ligação direta com o processo de criação.

Inicialmente, o trabalho técnico explorava os exercícios no solo, com as graduações de níveis até os movimentos locomotores. Esses exercícios eram passados para os corpos com deficiência através da transposição do movimento e do uso do espaço, como, por exemplo, o dançarino "andante" trabalhava o movimento da sua perna e o dançarino "cadeirante" fazia a correlação do movimento para seus braços.

A coreografia Clap sobre rodas mostra claramente a influência dessa fase. Criado em 1992 esse duo - interpretado pelas dançarinas Cláudia Fantin e Andréa Serrato - tem uma grande influência de uso de vocabulário de movimentos de coreógrafos da dança moderna, o que pode ser notado, por exemplo, nas qualidades dos movimentos de braços, que dão continuidade ao movimento do tronco (espiral de Martha Graham) e no uso da simetria de movimentos e da organização espacial.

Essa coreografia traz como materiais incorporados à dança uma cadeira de rodas e um skate, na perspectiva de serem elementos de locomoção e de exploração dos movimentos. As dançarinas começam sentadas ao fundo do palco, cada qual sobre um desses objetos, realizando os mesmos movimentos de braços que dão continuidade ao movimento do tronco no plano da "mesa", movendo-se de um lado para o outro. A cada deslocamento, fazem correlações de uso espacial e de movimentos, como, por exemplo, quando uma deita e desliza com o skate, a outra avança com a cadeira de rodas, o que vai gerando sincronias e alternâncias de movimentos e de locomoções. 


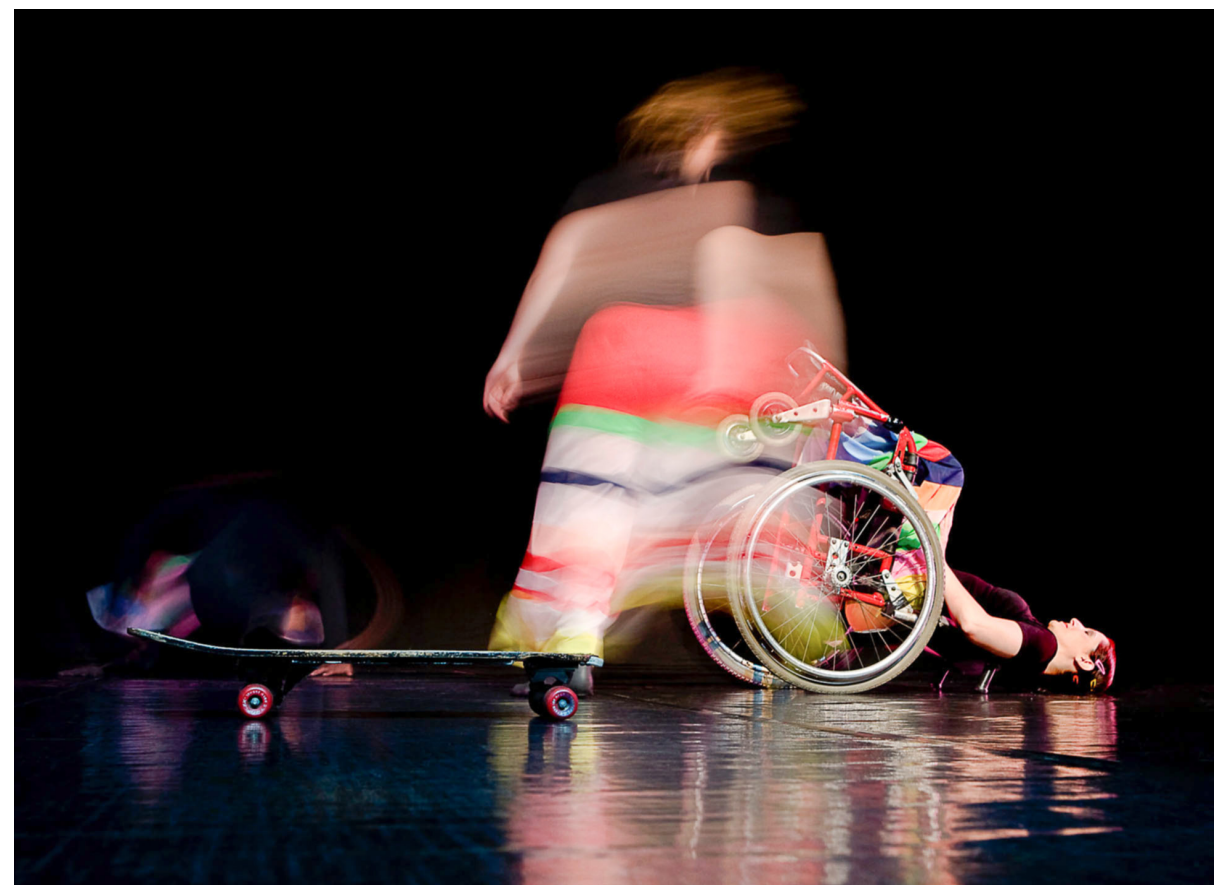

Figura 5. Coreografia: Clap sobre rodas. Limites Cia de Dança. Foto de Sérgio Vieira.

Em outra parte da coreografia, Andréa Serrato senta no colo de Cláudia Fantin e realizam movimentos simultâneos de braços e tronco, dando sequência a uma transferência de peso sobre a cadeira de rodas, com o corpo de Andréa Serrato sustentado na horizontal e Cláudia Fantin curvada à frente, apoiando as mãos no chão; assim, giram com a cadeira, como numa "carrega". Após, desfazem a forma e uma gira com a cadeira de rodas e a outra no seu entorno. A cadeira de rodas é inclinada para trás, até deitar o encosto no chão e, com a ajuda de Andréa Serrato, Cláudia Fantin, apoiando o corpo nos braços, faz um movimento de "bananeira", transferindo o peso do corpo para o chão.

No solo, trabalham a ação de impulsionar um corpo em contato com o outro, o que gera rolamentos e movimentos estimulados pelos braços, até que cada uma continua com esses impulsos, uma no nível do chão e a outra que segue até o nível alto e retorna ao chão. Com o skate elas deitam uma 
sobre a outra e, com as mãos, Andréa Serrato torna ativo o movimento passivo das pernas de Cláudia Fantin, realizando, em alguns momentos, as mesmas ações, o que conecta os dois corpos em um só movimento.

Após utilizarem mais uma vez a cadeira de rodas, enfatizando os movimentos de braços, as duas dançarinas vão ao chão, rolam juntas e, com o apoio dos braços, levantam o tronco e sentam puxando o quadril para o eixo de estabilidade da coluna, adotando, nesse movimento, a qualidade do corpo do cadeirante. Olham uma para a outra e repetem esse movimento até saírem de cena, abandonando os objetos de locomoção.

Mesmo que nessa coreografia haja poucas transposições de movimentos de uma parte do corpo para outra, fica clara a preocupação de encontrar soluções para que um mesmo movimento seja "adaptado" à singularidade de cada corpo. Após realizarem algumas pesquisas dentro dessa proposta de transferência de movimento de um corpo para outro, esse tipo de trabalho foi abandonado ao perceberem que o mais importante não era a transposição, mas o princípio gerador desse movimento.

A partir desse período, a coreógrafa começou a explorar mais os princípios do movimento - baseados nos fundamentos de Laban e Bartenieff - e os conhecimentos da aprendizagem motora, o que acabou resultando em um estudo denominado Progressão Qualitativa do Movimento. ${ }^{13}$ Para Andréa Sério essa proposta de trabalho continua em processo de sistematização, mas, de uma forma geral, visa a trabalhar didaticamente a compreensão dos contrastes e depois as nuances do movimento, através de elementos da aprendizagem motora como seletividade, atenção e progressão, valorizando, principalmente, como cada corpo percebe determinado conceito. Para Gustavo Lutke (2005), que, além de intérprete, há alguns anos assumiu o papel de professor do grupo, esse estudo

Proporciona uma mesma aula que 'cabe' em vários corpos. Então, didaticamente, torna-se muito mais simples de trabalhar [em] um grupo com diversidade, com corpos que se adaptam de forma diferente a essas situações. A parte criativa não fica só no momento da improvisação [...], mas também durante toda aula; até porque essa diferença dentro de cada objetivo que a gente tenta buscar dentro da aula é representada de forma diferente por cada bailarino, sendo ele 
portador de deficiência ou não. [...] todo mundo vai colocar sua personalidade, sua qualidade de movimento [...] em cada exercício ou trabalho.

Para Cláudia Fantin, a experiência de ter vivenciado a busca pela transposição do movimento em seu corpo com deficiência foi importante como aprendizado e "mostrou que é possível, mas não é bem o caminho. Hoje em dia, [...] a gente tem que usar muito mais a criatividade para atingir os mesmos objetivos". A consciência da percepção do próprio corpo, de suas potencialidades e uma reflexão sobre o conceito de dança também são ressaltadas por Gustavo Lutke, que após narrar suas diversas experiências em diferentes técnicas de dança, chega a conclusão de que: "hoje eu danço com a minha cabeça, com meu modo de pensar, com a maneira que eu observo as pessoas".

Alguns dos aspectos ressaltados pelos componentes do grupo sobre o preparo técnico na dança são também abordados por lannitelli (2004). Ao apontar a necessidade de transformações nas propostas metodológicas para o ensino da técnica da dança, essa autora enfatiza a importância do aspecto qualitativo no desempenho técnico-expressivo do dançarino, o qual é resultante de uma conscientização de tendências pessoais para a ampliação do vocabulário expressivo.

O grupo Limites, ao constatar que uma parte do corpo não pode substituir a função/ação de outra parte e que as possibilidades de movimento são pessoais, acaba se aproximando das ideias propostas por lannitelli, já que essa autora observa que as respostas corporais também dependem das idiossincrasias e das relações estabelecidas entre percepção/processamento/expressão do corpo de cada dançarino.

Assim, a pesquisa desenvolvida por Andréa Sério torna-se essencial para que se abra uma nova perspectiva sobre o treinamento em dança, que leve em conta também as singularidades de cada corpo, incluindo aqui o corpo do dançarino com deficiência.

Nesse sentido, vale ressaltar que, além dos resultados de treinamento, essa proposta pode contribuir para um melhor entendimento da performance do dançarino com deficiência, pois, como coloca Benjamin (2002, p. 9 , 
tradução nossa), "a performance de pessoas com deficiência não pode ser avaliada a partir dos parâmetros de uma técnica específica, mas, sim, pela visão geral dos elementos artísticos e das habilidades técnicas individuais."

Um reflexo dessa mudança de perspectiva na concepção do movimento pode ser percebido em In sono. Essa coreografia tem como tema a insônia e é interpretada por Alessandra Bittencourt, Cláudia Fantin, Rosângela de Lara e Luciana Gomes. A trilha sonora composta por Eliane Campelli utiliza sons do cotidiano (como pingos de água, descarga de banheiro, buzina de carro, latidos de cão, marteladas, ranger de portas, dentre outros), que são amplificados no sentido de transmitir a percepção de uma pessoa atordoada pela falta de sono e pelos barulhos da noite. Na coreografia In sono, a ambientação da cena nos remete a segmentos não lineares de uma casa, tendo: à esquerda do palco uma mesa baixa com uma bandeja de maçãs; na região posterior do palco, centralizadamente, duas almofadas; e, no lado direito, à frente, dois colchões com dois travesseiros.

Quando a cortina se abre, a dançarina Cláudia Fantin está em cena sobre um dos colchões, espaço esse que ela ocupará até o final da coreografia. Seus movimentos são bruscos, objetivando mudanças de posição do corpo de um lado para o outro, demonstrando uma impaciência na busca pelo sono, estando num estado de vigília, na qual a atenção corporal está mobilizada.

Enquanto isso, três dançarinas entram aos poucos no palco; seus movimentos possuem pouco tônus muscular e pouca prontidão, o que sugere um sono interrompido. Uma dançarina atravessa o fundo do palco num movimento de arrastar o corpo, com movimento pendular de um braço, como se fosse o ponteiro de um relógio; uma segunda dançarina entra fazendo o mesmo movimento, enquanto outra, na direção oposta, atravessa o palco com um movimento titubeante.

Esses movimentos são geradores de balanços, quedas e buscas de apoios, como se o corpo tentasse ceder ao cansaço, mas há uma desconexão de informações corporais vindas das redes neurais que continuam a deixar esses corpos em estado de vigília relaxada, mesmo que fadigados, desequilibrados e desorientados. Enquanto isso a dançarina Cláudia Fantin 
continua em um prolongado estado de vigília, atenta a todos os estímulos externos, lutando para ficar sonolenta.

Cada dançarina, em momentos diferentes, amplia o ritmo respiratório e deflagra um movimento repetitivo de uma parte do corpo após cada mudança de posição do corpo no espaço. O corpo resiste e uma das dançarinas vai ao encontro da dançarina Cláudia Fantin e estas passam a realizar movimentos de transferência de peso de um corpo para outro, com diferentes ritmos, buscando reconforto no corpo do outro. Ao mesmo tempo, as demais dançarinas continuam com os movimentos desconexos, com equilíbrio/ desequilíbrio, quedas, balanços, cujas repetições de movimentos não geram a "anestesia" corporal para a entrada no estado de sonolência. Elas comem, se ajeitam, mudam a posição do corpo e de lugar. Ao final da coreografia, as três dançarinas saem se arrastando, como se a falta de sono ainda resistisse ao cansaço corporal, e, na mistura de estímulos internos e externos, estivessem num estado ambivalente de vigília e sono. Enquanto isso, Cláudia Fantin, após insinuar comer uma maçã, ajeita o travesseiro e dorme.

De uma forma geral, essa coreografia já mostra uma pesquisa individual de movimentos e as articulações propostas pela coreógrafa, sem ficar centrada em transpor o movimento de um corpo para o outro. Por outro lado, a estética coreográfica é ainda predominantemente permeada pelo vocabulário dos corpos dos dançarinos sem deficiência, não sendo amplamente investigadas as qualidades específicas do corpo dançante com deficiência.

Apesar de Andréa Sério e Gustavo Lutke enfatizarem a preocupação do grupo com a investigação de alternativas metodológicas para o ensino da dança, que incluam as diferenças corporais, nos dados obtidos na entrevista, encontramos conceitos divergentes sobre o corpo, que mostram em alguns momentos a anulação da diferença por meio de uma meta-pasteurização - "todo mundo é diferente, naturalmente [...], todo grupo tem um tipo de inclusão” (Gustavo Lutke, 2005); “é todo mundo igual”. (Cláudia Fantin, 2005) Em outros, apontam para uma consciência da real diferença corporal:

Embora a gente diga somos todos diferentes, visivelmente [a pessoa com deficiência] é diferente de você. Então essas questões a gente não pode negar, elas existem (Sério, 2005). 
Eu não posso ir numa academia comum fazer exercícios de alongamento e de peso como uma pessoa comum, porque eu não sou uma pessoa comum. Eu tenho limitações que eu tenho que respeitar e tenho que trabalhar essas limitações de uma forma tal que eu não venha a ter prejuízo mais tarde [...] e com a dança também. (Bravo, 2005)

Outra perspectiva conflitante surge no depoimento desse mesmo dançarino, Paulo Bravo, no qual aflora a anulação da parte do corpo "sem controle": "o importante é a comunicação com aquela parte do corpo que você domina [...]. Quem não domina as pernas, trabalha com os braços, com a cabeça, com o olhar". Outra dançarina com deficiência, Cláudia Fantin, ressalta a necessidade da consciência corporal na relação com o outro: "eu acho que vai muito também de como que a gente se coloca; de como o portador de deficiência é; do conhecimento do corpo, das suas limitações e das possibilidades [...] e de como que a gente se coloca também perante esses bailarinos convencionais".

Essa divergência de conceituações em relação à diferença/deficiência revela, em alguns momentos, o que Bavcar (2003) denomina de maquiagem conceitual do corpo deficiente. Para esse autor "o corpo deficiente decorre apenas de uma consciência de corpo um pouco mais aguda e um pouco mais dolorosa sem poder dizê-lo, devido a toda a aparelhagem conceitual que impede essa mesma consciência de dizer a sua própria visão da história." (BAVCAR, 2003, p. I77) E mais à frente em seu texto completa "por que é que a ideia do deficiente invadiu a história contemporânea? Falar do corpo ferido, designar o outro como diferente de nós, é tentar acreditar na possibilidade do corpo ideal, perfeito." (BAVCAR, 2003, p. I88)

A perspectiva apresentada por Bavcar também proporciona um outro ponto de vista, já que precisamos perceber que a diferença está instaurada em cada ser, em cada singularidade, independente de ser uma pessoa com ou sem deficiência, mesmo que persistam na nossa sociedade fortes estereótipos que sustentam a homogeneização de padrões corporais.

Outro aspecto a ser abordado refere-se ao consenso do grupo sobre a importância dos processos criativos, tanto na preparação técnica, quanto na construção coreográfica, já que os dançarinos também participam do processo de criação, cujos resultados são “costurados” pela coreógrafa. 
Assim, mesmo as coreografias sendo dirigidas e concebidas por Andréa Sério, a partir de temas, ideias ou pesquisa de movimentos, o resultado da investigação em si, depende muito da disponibilidade e das possibilidades corporais dos dançarinos.

Para realizar observações e análises críticas do processo, o grupo adota o recurso da filmagem como forma de acompanhamento. As dificuldades e desafios encontrados no processo de criar são narrados pelo grupo:

[No início] existia no processo de composição sempre uma certa expectativa, principalmente dos bailarinos com deficiência, de que para com os outros, [os bailarinos sem deficiência], não houvesse essa mesma busca [criativa do movimento]. [...] Eles imaginavam que isso só acontecia pelo fato deles terem uma deficiência [...]. Quando começaram a ter contato com outros bailarinos que já tinham também uma história na dança, perceberam que pra todo mundo é esse trabalho - de novo e de pesquisa; não só de novo no sentido de ensaio, de repetição, mas de processo mesmo. Você percebe o amadurecimento deles em relação ao conhecimento do próprio corpo e, nesse aspecto, [a proposta de] Laban ajudou muito: sistematizar, conhecer e começar a ver outras maneiras de usar o corpo, outras maneiras de usar diferentes qualidades de movimento. (Sério, 2005)

Sempre fui um bailarino voltado para a dança clássica e tive um convite pra dançar [na Limites]. Tive que rever todos os meus conceitos e me encontrei numa área da dança que até então pra mim era desconhecida e tive que reformular essa questão de pensar o movimento, formar um novo sistema do meu vocabulário motor. (Lutke, 2005)

Pra todo mundo é dificil, a pesquisa e movimento. Pra qualquer pessoa é difícil. Talvez, acredito, que pra nós seja um pouco mais dificil, pra quem porta algum tipo de deficiência [...]. Hoje eu já me conheço um pouco mais, mas essa dificuldade de conhecer o próprio corpo é um pouco maior [...], hoje eu vejo que [existe] pra todo mundo essa dificuldade de pesquisa de movimento. (Fantin, 2005)

Isso é que é bacana [...]. Você não consegue em corpos singulares, reproduzir no teu aquilo que é do outro. (Sério, 2005) 
Algumas dificuldades encontradas durante a pesquisa de movimentos também aconteceram no processo inicial de encontro dos corpos com e sem deficiência. Surgiram receios, dúvidas quanto às possibilidades e limites: "quando eu fui pegar uma coreografia que eu fazia com a Cláudia, era muito difícil pra mim, entender aquele corpo que era diferente do meu, sim. Então eu tinha um pouco de receio e eu comecei a aprender com essa diversidade corporal." (Bittencourt, 2005) Essas barreiras só foram quebradas no processo de interação.

Apesar de todas as dificuldades inerentes ao processo de criar e de conectar diferentes fisicalidades, o grupo não quer ser identificado, devido à sua característica de trabalhar a diversidade, como um grupo de dança inclusiva. Sobre esse assunto, Andréa Sério (2005) é categórica: “acho que na medida em que a gente precisa usar esse tipo de termo é porque a gente ainda não conseguiu compreender e vivenciar a dança contemporânea".

Além da questão da delimitação do campo de atuação do grupo, Andréa Sério também fala da incompreensão de muitos profissionais da área da dança quanto à sua proposta:

Há muitos anos atrás [...] iniciar esse assunto dentro de um curso superior de dança, parecia que você estava, assim, pirando. Sabe eu já escutei de gente bacana da dança coisas do tipo: mas o que você quer com isso, Andréa? Você quer virar a rainha dos deficientes? [...] pra mim estava muito claro o que eu queria e eu achava incompreensível que aquelas pessoas, que me ensinaram tanto sobre dança contemporânea, não conseguissem compreender aquilo que me parecia uma coisa tão lógica, tão natural da dança contemporânea [...]. O que é complicado que a gente vê, é que mesmo no âmbito da criação da dança contemporânea a gente ainda tem necessidade de se segregar. (Sério, 2005)

Essa consideração de Andréa Sério está em consonância com relatos de outros artistas, principalmente dos com deficiência, que enfatizam as barreiras culturais existentes na dança sobre quem pode ser bailarino e sobre o que é dança, como já foi citado no depoimento de David Toole.

Considero que uma mudança radical nesse cenário dependerá também do dançarino com deficiência perceber-se como uma voz ativa na dança, como 
um corpo político, que, liberando-se da maquiagem conceitual, hierárquica e estética que camufla a diferença, possa apresentar-se na dança a partir da singularidade de ser um dançarino com deficiência que dialoga com o contexto.

No que se refere à estética do grupo, durante a entrevista realizada, a diretora e coreógrafa Andréa Sério narrou a influência da dança moderna alemã no seu trabalho e afirmou que, ao longo desses anos, vem trabalhando com coreografias curtas, que são na maioria das vezes muito diferentes entre si, não possuindo um único viés estético.

A coreografia Passagens exemplifica bem a influência da estética expressionista. Nesse duo com música de John \& Vangelis, interpretado por Cláudia Fantin e Gustavo Lutke, as emoções são o foco central. O cenário é formado por dois bancos, com alturas diferenciadas, que são colocados no lado direito do palco e um banco mais alto, no lado esquerdo, com uma grinalda que fica estendida até o chão.

Os três bancos são alinhados na diagonal. A existência de dois focos, um para cada parte desse cenário, fortalece a questão imagética da cena que nos dá uma sensação de abandono.

Sobre o banco mais alto do lado direito está Cláudia Fantin, deitada lateralmente, vestindo um longo vestido branco. Quando a música começa a tocar a dançarina faz um movimento de sentar e deitar lateralmente, utilizando bastante o peso do seu corpo. Ao mesmo tempo o dançarino entra na diagonal do fundo rolando, recolhe para seu corpo a grinalda e, com movimentos contínuos de rolar e girar, sobe e desce do banco, continuando seu movimento até chegar ao local onde está a dançarina. Gustavo Lutke segura Cláudia Fantin pelas costas e realizam, de braços estendidos e mãos dadas, um movimento que remete a uma dança de salão que, contraditoriamente, fica presa a um lugar. Gustavo Lutke ocupa o banco ao lado de Cláudia Fantin e, juntos, realizam os mesmos movimentos de tronco e braços.

Apesar de o dançarino estar em cena o tempo todo, parece que Cláudia Fantin dança com um espectro. Eles seguem sobre o banco, entregando o peso de um corpo ao outro, alternadamente. Os corpos parecem não resistir e se extasiam no prazer do contato. Eles saem do banco e dançam no centro do palco realizando movimentos de dança de casais, agora sim com uso do 
espaço e com movimentos de passagem e carregas, lançando o corpo de Cláudia Fantin para frente e para trás do corpo do dançarino. Um corpo busca o outro e os movimentos oscilatórios extravasam a perda de eixo; estão fora de si, cheios de desejo. Lutke coloca Cláudia Fantin novamente sobre o banco e ela volta a fazer o primeiro movimento de deitar e sentar, utilizando o peso do seu corpo. O dançarino pega a grinalda e sai rolando do palco. A dançarina fica só, mas, com o corpo repleto de memórias inscritas na carne.

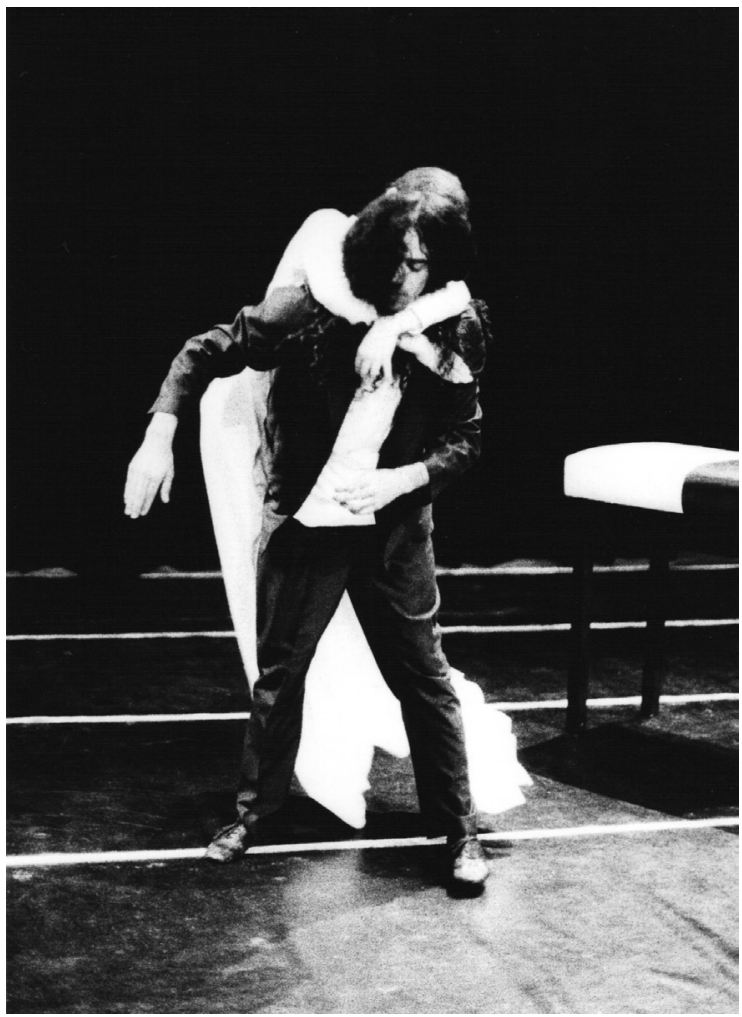

Figura 6. Coreografia Passagens. Limites Cia de Dança. Foto de divulgação.

Todos os exemplos aqui analisados das coreografias mostram o que Andréa Sério considera como uma estética em transformação. Em suas criações, ela tem uma preocupação central de não tornar o trabalho piegas ou paternalista em decorrência da inclusão de bailarinos com deficiência, e nem chocar o público com uma pesquisa estética mais radical. 
Apesar de Sério afirmar ter tido durante muitos anos uma preocupação em estabelecer um diálogo direto com o público, esse preceito está sendo revisto e, segundo a coreógrafa, ela começa a focar mais sua atenção no processo/produto artístico em si e na possibilidade futura de criação de um espetáculo com uma única concepção coreográfica.

Entretanto, aponto que as coreografias aqui analisadas, ao trazerem a priori preocupações sobre o entendimento do público da obra coreográfica e a preocupação com a apresentação de uma estética mais próxima das normas do "esteticamente correto" (SODRÉ; PAIVA, 2002), faz com que a Limites, por meio do excessivo polimento estético, muitas vezes apague as diferenças.

Vale registrar que essa excessiva preocupação com o entendimento do público pôde ser registrada durante a apreciação do espetáculo no Teatro José Maria Santos, em julho de 2005. Antes de cada coreografia, foi apresentado oralmente um breve release sobre a concepção da obra, o que acaba influenciando a "leitura" da obra de arte pelo público.

Como explana Pareyson (1993), a experiência estética é vital, tanto para a leitura da obra de arte, como para a reflexão filosófica, e essa relação não pode ser substituída por uma descrição da obra, já que "o valor teórico ou prático dessas obras não se me revela a não ser que eu veja, ao mesmo tempo, o seu valor estético." (PAREYSON, 1993, p. 23, grifo nosso) Complementando essa perspectiva, Susan Sontag (1987) defende a ideia da erótica da arte, de que devemos novamente aprender a olhar e a não criarmos de antemão uma leitura da obra de arte.

Nesse sentido, seria mais interessante que o produto coreográfico falasse primeiramente por si só, apresentando o pensamento do corpo que dança e que a apreciação em si fosse o elemento gerador de reflexões, podendo ser adotado o debate após a apresentação, numa perspectiva de favorecer a intermediação entre a obra, a plateia e os criadores-intérpretes.

Um segundo exemplo da evolução da concepção coreográfica da Cia. Limites pode ser percebido na coreografia Disforme (2002). Apesar dessa coreografia não ter feito parte do repertório selecionado para a apresentação no Teatro José Maria Santos, é importante salientar a presença de uma grande contaminação de informações do ambiente contemporâneo, 
resultando na exploração da fragmentação do movimento, na simultaneidade de ações em cena e na maior exposição das diferentes corporeidades, iniciando-se, assim, uma possibilidade de reconfiguração do material estético da companhia.

As análises das entrevistas e do repertório coreográfico dessa companhia possibilitaram perceber que ainda há um hiato entre as firmes posições apresentadas, principalmente, pela diretora do grupo, no que se refere à estética, ao papel do dançarino com deficiência, à postura política e ao resultado coreográfico.

Ao longo desses anos, os dançarinos adquiriram uma maturidade artística, tendo em seus corpos uma rede de informações sobre dança, o que possibilita que o grupo desenvolva uma pesquisa de movimento que coloque o corpo no centro da questão.

Esse tipo de busca poderá gerar no grupo a afirmação de uma assinatura pessoal da coreógrafa, distanciada da preocupação de que o produto artístico apresente signos de fácil compreensão, no intuito de facilitar o entendimento pelo público, preocupação esta citada na fala da diretora.

Além disso, essa perspectiva pode suscitar também uma estética singular do grupo, que abarque as diferenças presentes no seu âmago, o que possibilitará dialogar de uma forma mais autônoma com as influências da diversidade estética da própria dança, como foi enfatizado pela coreógrafa no início desta análise ao falar da presença em suas coreografias do trânsito “do expressionismo alemão até a pós-modernidade".

As competências artísticas desse grupo são evidentes, tendo o mesmo sido responsável por uma inovação no panorama nacional, ao colocar na cena dançarinos com e sem deficiência, apresentando produtos com qualidade artística. Além disso, a Limites influenciou outros artistas a trilharem caminhos similares, como veremos em depoimento de um membro da Pulsar Cia. de Dança.

As possibilidades aqui sugeridas podem trazer ao grupo uma profícua desestabilização. Como explana Morin ( I99I), a inovação provoca uma desorganização, que promove uma ação ligada ao princípio da reorganização, o que gerará novos pensamentos de dança no grupo. 
Assim, esse momento poderá facilitar a emergência de uma pesquisa mais centrada na alteridade e no pensamento das singularidades das diferentes paisagens corporais (DAMÁSIO, 1996) presentes nesse grupo e nas relações estabelecidas com o ambiente.

\section{Pulsar Cia. de Dança}

Teresa Taquechel - diretora, coreógrafa e dançarina da Pulsar ${ }^{14}$ - iniciou suas atividades na dança aos 14 anos de idade. Sua primeira graduação foi em química e só depois de passar uns anos no exterior, ao regressar ao Brasil, entrou na Faculdade Angel Vianna, no Rio de Janeiro, no intuito de realizar o curso de reabilitação motora.

Ao longo de sua formação acadêmica na Faculdade Angel Vianna, Teresa Taquechel foi ampliando seu interesse pela composição coreográfica. $O$ direcionamento de seu trabalho com pessoas com deficiência só foi aguçado já no final do curso por meio de um workshop de contact improvisation com Bruce Curtis, um dançarino cadeirante, membro da Paradox Dance Company, da Califórnia (USA).

A experiência desse workshop e o convívio com alguns dançarinos com deficiência geraram a formação de um grupo de estudos sobre dança com pessoas com deficiência na faculdade. Após um período de trabalho experimental, com a orientação da própria Angel Vianna, Teresa Taquechel e mais duas colegas começaram a atuar no Hospital do Aparelho Motor Sarah, com o trabalho de dança e consciência corporal no tratamento de portadores de lesões medular e cerebral. Teresa Taquechel atuou no Sarah de Brasília durante um ano (1994), e essa experiência mais próxima da terapia forneceu à Tereza um conhecimento teórico e prático sobre as possibilidades e limites do movimento do corpo com deficiência.

$\mathrm{Na}$ volta ao Rio de Janeiro, Taquechel fez parte, durante sete anos, como dançarina, diretora e assistente de direção, do grupo Ra Tame Tanz, dirigido em parceria com Alexandre Franco. Paralelamente a essa atividade ela prestava atendimento terapêutico para pessoas com deficiência. Nesse entre- 
meio, conheceu o trabalho de Bete Caetano, uma dançarina com deficiência e, juntas, começaram a pesquisar e oferecer cursos de dança para dançarinos com e sem deficiência.

Somente em 2000 é que Tereza Taquechel e mais três dançarinos - Rogério Andreolli, Andréa Chiesorin e Fernanda Rocha - fundam a Pulsar Cia. de Dança, uma companhia profissional de dança contemporânea que faz parte do Núcleo Coreográfico da Escola e da Faculdade Angel Viana. ${ }^{15}$ Inicialmente, o grupo começou a ensaiar no Liceu Escola de Dança, em Botafogo, e realizou algumas pesquisas no Serviço Social do Comércio (SESC) Copacabana. Em 2005, o Centro Coreográfico do Rio de Janeiro cedeu uma sala para ensaios, durante um período de quatro horas, duas vezes na semana, tornando a Pulsar um grupo residente do Centro Coreográfico.

Esse Centro é um espaço subvencionado pela Prefeitura Municipal do Rio de Janeiro e é "direcionado para a pesquisa, criação, desenvolvimento, apresentação, documentação e difusão da arte da dança, integrado ao movimento artístico e cultural do país e do mundo." (CENTRO COREOGRÁFICO, 2006) Vale ressaltar que o Centro Coreográfico é todo adaptado, o que possibilita a acessibilidade para os artistas e do público. A entrada da Pulsar nesse importante espaço de fomento à dança já demarca uma quebra de fronteiras e aponta um reconhecimento da qualidade artística da companhia.

Outro aspecto a ser registrado refere-se às influências do grupo. Além da marca da trajetória pessoal de Tereza Taquechel na concepção do grupo, Andréa Chiesorin, membro-fundadora da Pulsar, sinaliza a influência exercida pelo grupo Limites (PR), cuja empatia pela proposta artística foi um impulso para a busca de uma estética própria na dança. Em suas palavras:

Quando eu vi pela primeira vez um trabalho profissional que foi a Limites, eu me encantei com o trabalho, com aquela coreografia dos andaimes. Percebi que eu queria buscar essa pesquisa estética, que era possível dançar com a pessoa com deficiência e atingir um nível profissional. (Chiesorin, 2005) 
Em 2005, a Pulsar possuía dez componentes, entre bailarinos e atores (oito andantes e quatro cadeirantes), sendo um deles uma dançarina com paralisia cerebral.

Segundo consta nos releases do grupo, Rogério Andreolli, além de ser ator formado pela UniverCidade, em 2003, tornou-se o primeiro bailarino profissional em cadeira de rodas no Brasil.

É importante salientar que a Pulsar preferiu frisar em seu nome a identificação de ser uma companhia de dança para evitar a identificação com o termo dança inclusiva. Teresa Taquechel é taxativa:

Eu tenho dificuldade com essa palavra 'dança inclusiva'. Na verdade, eu já discuti com a Andréia isso bastante, eu não gosto. Não gosto porque eu entendo até o processo, até entendo que a gente tenha que passar, talvez, por essa ideia da 'dança inclusiva'. Mas eu tenho medo disso se estratificar e a gente perder muito tempo. No Brasil, principalmente, essa questão da dança com pessoas que tem deficiência está sendo tudo muito rápido; as pessoas não tem nem tempo pra rotular. Acho que é perda de tempo, porque você vai segregar. Na verdade, a ideia é que essa dança, dança inclusiva, faça parte da dança, faça parte do universo da dança e não que tenha um nome 'dança inclusiva' então é: ah, é dança com deficiente. Não. Eu quero que veja já como bailarino, um bailarino que por acaso é deficiente. (Taquechel, 2005, grifo nosso)

Apesar de Taquechel ter convicção com a inadequação desse termo, isso não é consenso no grupo. Andréa Chiesorin considera que não é um termo adequado para uma companhia, mas considera importante como processo.

[...] [vejo] a dança como um processo inclusivo, como um processo terapêutico. Essa dança vai permitir que as pessoas que se sintam excluídas de um processo, permita que elas venham a dançar. Mas eu não acho que isso deve ser nome pra dança em si, como um rótulo entende. (Chiesorin, 2005)

Vale ressaltar que Chiesorin é membro da diretoria da Associação Vida e Sensibilidade, tendo sido responsável, no ${ }^{\circ}$ Festival Internacional Arte sem 
Barreiras, em 2002, pela programação de dança e esse termo foi adotado nesse evento. Ainda no que se refere ao termo dança inclusiva, Rogério Andreolli (2005) tem um posicionamento dúbio:

[...] dança em cadeira de rodas, dança inclusiva, dança com portadores de deficiência, pra mim, é apenas uma nomenclatura, entendeu. O que importa, pra mim, é dançar. $O$ nome que se dá não importa; o que importa é como eu me sinto em relação a isso. Sou a parte realmente interessada; pouco [importa] enquanto deficiente o nome. Enquanto artista, eu fico 'puto' quando vai muito preconceito embutido.

Além das atividades artísticas, a Pulsar Cia. de Dança "vem ministrando palestras e workshops sobre dança e inclusão, com o objetivo de difundir suas experiências teórico-práticas e contribuir de forma ativa e atual na discussão da inclusão social.” (Pulsar, 2005) Nos cursos ministrados por Tereza Taquechel são abordados temas relacionados à dança contemporânea para dançarinos com e sem deficiência, e dança e recuperação motora através da conscientização do movimento.

A coreografia Pulsar, criada em 200I (a única versão completa montada até o primeiro semestre de 2006), ou partes desta, foi apresentada em diversas cidades do país, no Internacional Very Special Arts Festival (Washington, 2004), em festivais nacionais do Arte sem Barreiras e em vários festivais não segmentados, tais como: Dança em Trânsito (2005); Circuito SESC (2004); Circuito Carioca do Rio de Janeiro (2003), Novíssimos do Panorama RioArte (200I); Festival de Dança de Florianópolis (2002); Festival de Uberlândia (2002); Festival de Dança de Campina Grande (2003), dentre outros.

Outro aspecto a ser ressaltado refere-se à homenagem recebida pela Cia. Pulsar, em 2004, através da Ordem do Mérito Cultural, cujas insígnias foram recebidas das mãos do presidente Luis Inácio Lula da Silva e do Ministro da Cultura Gilberto Gil. Apesar do rápido reconhecimento atingido pelas instâncias governamentais e pelo público, a Pulsar tenta transpor todas as adversidades encontradas para a manutenção de um grupo de dança no Brasil, como por exemplo, a impossibilidade de uma remuneração 
mensal para seus dançarinos, sem a existência de um patrocínio fixo ou edital específico para sua manutenção.

Como toda companhia, a Pulsar também passou por mudanças no quadro de dançarinos, mas, para a diretora, a possibilidade de manter o mesmo elenco é essencial para o tipo de trabalho desenvolvido pelo grupo, já que sua pesquisa parte das diversas qualidades geradas pelos corpos diferentes e "isso só se consegue ao longo de um trabalho", necessitando assim de um processo contínuo e não pontual para a criação de um determinado espetáculo.

Até 2005, a falta de um apoio constante para a subsistência do próprio grupo acabou influenciando num menor investimento em novas criações, e optou-se pela manutenção do repertório Pulsar e a apresentação de partes desse espetáculo ou releituras denominadas como Bambu, Faixas e Pulsar Fragmentos. Isso acarretou uma fragilidade no grupo no que se refere a uma renovação criadora, bem como deixou a Pulsar distanciada de pólos artísticos que privilegiavam em suas programações a apresentação de obras inéditas. Somente no final de 2005 é que a companhia começou a criar uma nova coreografia, , sob a coordenação do coreógrafo convidado Alexandre Franco, naquela época professor e coordenador da Escola Angel Vianna.

$\mathrm{Na}$ entrevista grupal, quando abordamos questões específicas sobre a estética do grupo, o aspecto mais enfatizado foi a especificidade do corpo, como elemento gerador da estética da Pulsar:

[...] eu busco uma coisa muito sensorial, assim, trabalhar através da sensorialidade. Não são os movimentos por si só e não são movimentos que buscam uma coisa acrobática [...]. Acho que é muito mais uma coisa sensorial, de como o movimento percorre o corpo, qual a sensação que o bailarino tem ao dançar e como é que a gente passa isso pro público. Meu olhar passa muito através disso, dessa sensorialidade misturada com a plasticidade, que é muito estético. Realmente, acaba que surge uma estética muito específica. (Taquechel, 2005)

[...] a pesquisa estética que a gente desenvolve ela é extremante contemporânea, no que diz respeito ao que pode um corpo. A gente vê que um corpo pode muito, 
então, a pesquisa que [Teresa] desenvolve [...] busca o resultado no corpo da gente. Realmente, a gente fala muitas vezes de um exercício que é uma 'mola' que vai reverberar, que vai dar um contorno nesse corpo diferente, ou um movimento que a gente chama de 'água' que é todo um movimento pequeno no corpo e que vai resultar num outro movimento. A gente trabalha com muitas qualidades de movimento e como fazemos muita aula entre nós, bailarinos com e sem deficiência, [isso] nos dá um vocabulário estético muito interessante, um vocabulário de que o nosso corpo pode investigar outros caminhos. (Chiesorin, 2005)

Para que o grupo alcance essa estética almejada, o treinamento é um importante momento do trabalho coletivo. As aulas eram conduzidas por Andréa Malaguti, João Oliveira e a própria Tereza Taquechel e envolviam etapas de aquecimento, uso de técnicas de consciência corporal, Pilates e contact improvisation, para posteriormente entrarem no processo de criação.

Para Tereza Taquechel (2005) o trabalho de consciência corporal é fundamental:

[...] da Angel [Vianna] acho que existem várias técnicas de consciência [...]. Eu me identifico muito com a questão da consciência e da estrutura óssea, primeiramente, de como você lida com esses ossos. Como é que você, na verdade, tem a percepção interna desses ossos e, evidentemente, uma percepção articular. Depois disso, você tem o contorno que é a pele, que é por onde a gente recebe informações e por onde a gente dá informações. Na verdade [...] [a] consciência ti permite estar com os canais muito abertos, vários canais. E aí vem essa técnica de apoio, pressão, não é necessariamente você trabalhar só com a força, mas de pressionar e, como eu já estou sentindo sua tíbia, que eu já sinto seu volume. Por isso que eu falo precisa de uma pesquisa; isso você não adquire da noite pra o dia. Então as coreografias surgem a partir dessas técnicas que são preparadas nos laboratórios, no próprio aquecimento.

trabalho de consciência do movimento traz uma perspectiva diferenciada para o corpo do dançarino. Rogério Andreolli (2005) ressalta diferenças encontradas entre as aulas de técnica na faculdade de teatro e o trabalho na companhia: 
Eu lembro que eu tinha uma professora de expressão corporal [...] e que ela levou seis meses mais ou menos para me tocar. A gente começava com alongamento e lá pelas tantas ela passava a mão nas costas de um, para 'abrir' as costas e 'abrir' a musculatura e tal, e quando chegava na minha vez, ela pulava. Eu tinha um acordo, um 'pacto' com ela, de que eu faria aquilo que fosse possível, aquilo que não fosse, que fosse 'perigoso' eu me manteria fora do exercício. Até que um dia, teve uma brincadeira lá com bastões e ela me olhou com cara de quem 'não, você fica de fora', e eu olhei para ela de volta e 'não, eu quero fazer', e entrei. Como todos os outros eu levei bastonadas na cabeça, o bastão caiu no meu pé, aquela coisa, e isso aconteceu não só comigo, mas com todos os outros. Daí por diante eu comecei a ficar cada vez mais ousado.

[...] quando eu passei pra Pulsar é que eu comecei a tomar consciência do que era cada coisa [peso, base etc.], 'dar nomes aos bois' e aí comecei a entender melhor o mecanismo. Passou daquela coisa um pouco abstrata, meio intuitiva, pra uma coisa mais consciente, mais cerebral e isso, com certeza, mudou a minha postura, a minha visão sobre $a$ dança.

Ao abordar seu processo de criação, Teresa Taquechel afirma que não apresenta movimentos prontos para os dançarinos e que sua criação parte muito das informações geradas nos corpos dos dançarinos, ao que ela vai "lapidando e vendo o que é que interessa e aí eu boto determinada qualidade, determinado ritmo." (Taquechel, 2005)

Ainda discorrendo sobre as características do trabalho da Pulsar, essa coreógrafa afirma que os estímulos para a pesquisa do movimento são baseados em imagens, explorações do próprio movimento ou sensações, não usando o viés emocional para a constituição do movimento:

[Trabalho] muito mais em termos da sensorialidade daquele corpo e da resposta do movimento. No emocional, eu tenho uma dificuldade muito grande, não gosto [...]. Me encanta muito mais, eu sou apaixonada, como aquele movimento gera uma emoção. E eu sempre digo pro Rogério, que é ator: olha, não me bote um personagem. Não me bote uma emoção antes do movimento. Deixa esse movimento te impregnar. (Taquechel, 2005) 
Essa preocupação com a sensorialidade é perceptível no espetáculo homônimo do grupo. Esse primeiro espetáculo estreou em dezembro de 200I, com recursos do Programa de Incentivo às Artes da Secretaria Estadual de Cultura do Rio de Janeiro (ProCena); em 2002, voltou a cartaz no Conjunto Cultural da Caixa no Rio de Janeiro e, em 2003, com o apoio da Poupança da Caixa, esse grupo se apresentou no Distrito Federal.

No programa de Pulsar (2005) é indicada, como elemento gerador de suas pesquisas, a busca por "uma singularidade na diferença. $A$ identidade de cada intérprete é fonte de criação, um estímulo ao olhar em relação à multiplicidade do indivíduo".

No espetáculo são utilizadas técnicas circenses, dança contemporânea e os figurinos e cenários compõem a plasticidade e transformam-se em elementos compositivos do movimento nas cenas.

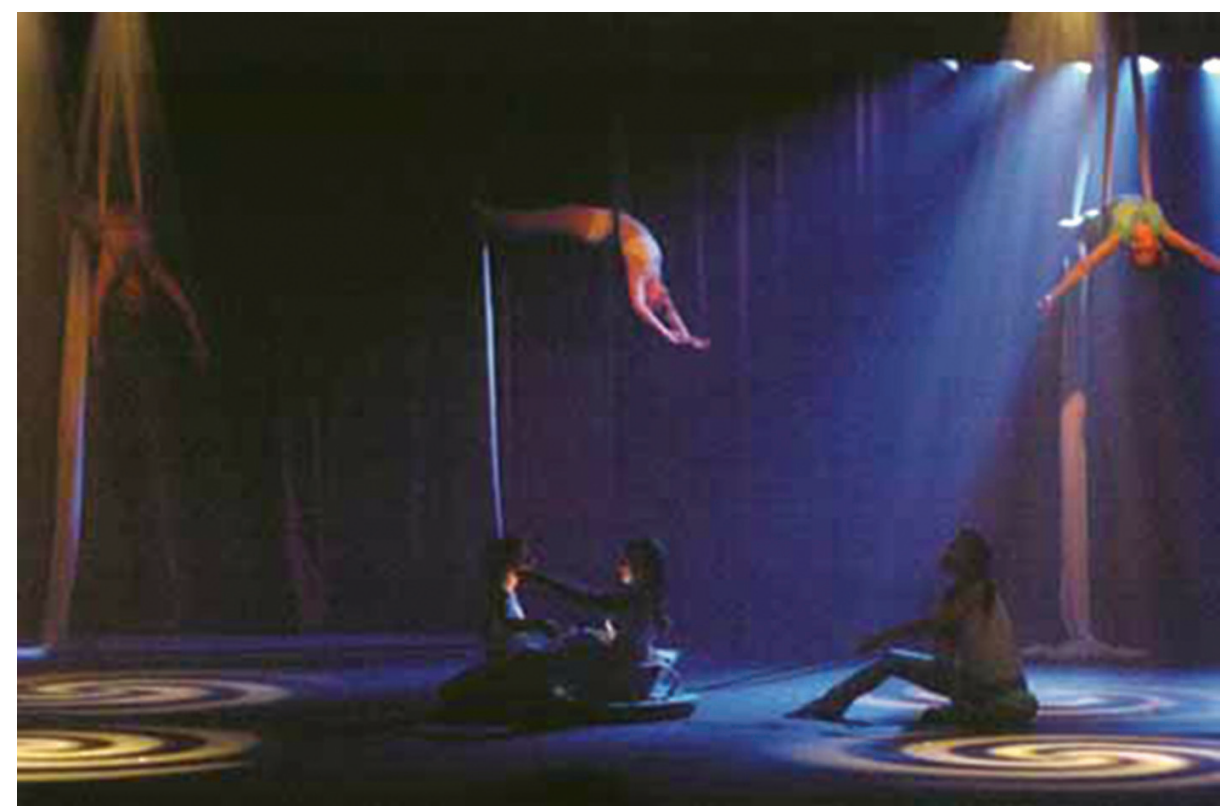

Figura 7. Coreografia: Haploos (a). Pulsar Cia. de Dança. Foto: Mauro Kury. 


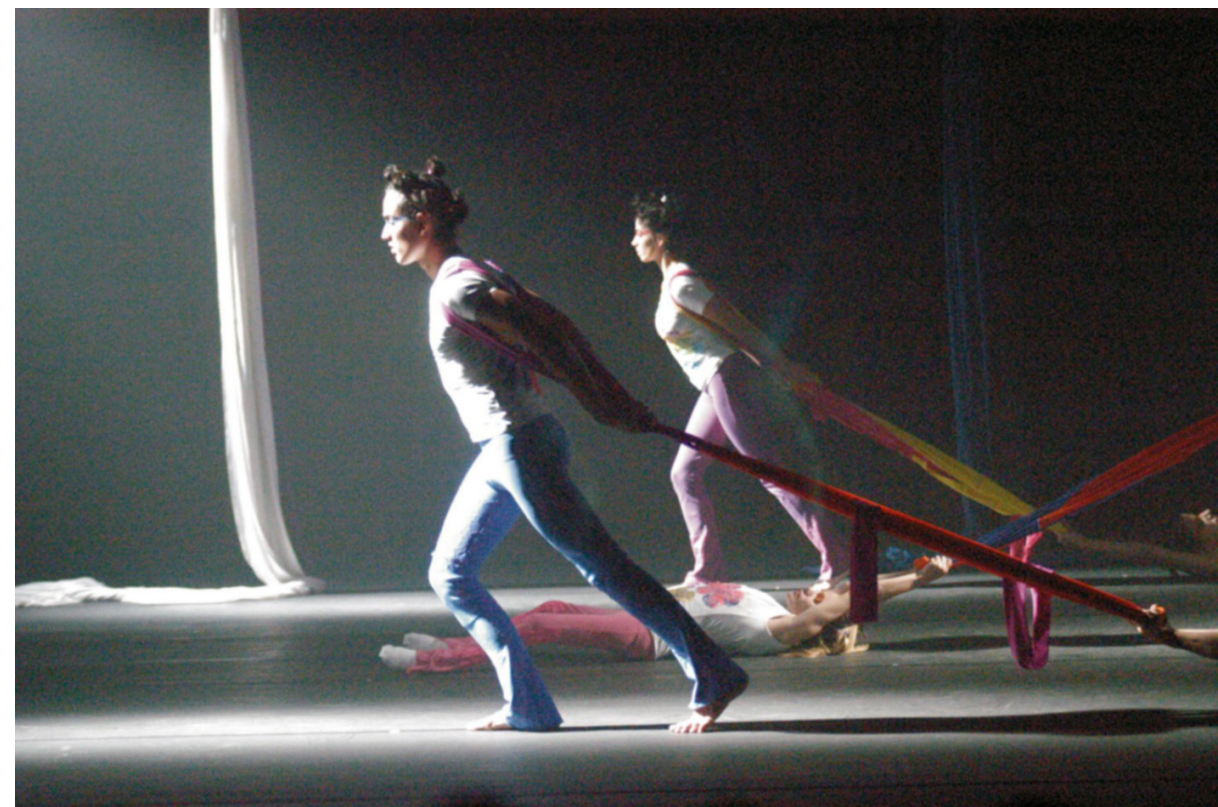

Figura 8. Coreografia: Haploos (b). Pulsar Cia. de Dança. Foto: Mauro Kury.

O processo de criação do espetáculo Pulsar teve que ser acelerado para dar conta do prazo de três meses estabelecidos no edital do ProCena para a realização do espetáculo. Por esse motivo, algumas mudanças precisaram ser feitas, como aponta a coreógrafa:

Na verdade, não era o que eu queria como primeiro espetáculo da companhia. Eu queria, na verdade, por exemplo, que aquele primeiro ato fosse um espetáculo só. A gente estava começando uma pesquisa de aéreos com eles. A questão da deficiência trabalhada em cima dos aéreos. (Taquechel, 2005)

A primeira parte do espetáculo é denominada de Haploos e tem 24 minutos de duração. Essa palavra de origem grega haplós ou haplóos significa simples, único sem artifício, e segundo consta no dicionário Houaiss (200I), esse termo foi muito usado como antepositivo nas ciências naturais, a partir do século XIX, para a definição de aspectos como a morfologia, por exemplo. 
Essa relação com a plasticidade da forma também está presente no espetáculo. A música concebida por Bernardo Gebara, com características eletrônicas, cria uma atmosfera que alude, na primeira parte da coreografia, à ambientação de filmes de ficção científica.

A coreografia inicia-se com três faixas dependuradas e três dançarinas arrastando-se pelo chão com movimentos contralaterais de braços e pernas, alternados com movimentos ondulatórios de tronco realizados na horizontal. Com o tronco sempre mais alto e com movimentos espinhais, elas continuam a arrastar-se até chegarem às faixas. Com a parte inferior do corpo anulado, as dançarinas se dependuram nas faixas, começam a escalar com os braços e as pernas retomam a sua funcionalidade. Enrolam-se no tecido, contribuindo para uma subida mais rápida. Quando chegam ao alto, organizam seu espaço e cada uma se coloca no meio da faixa, construindo um casulo.

Pelos dois lados do palco, começam a entrar em cena corpos-invólucros, cujas diferentes formas de conexões corporais instauradas dentro do tecido exploram diversos tipos de locomoção. As imagens geradas por esses corpos-invólucros se assemelham a movimentos de amebas, moluscos e anelídeos; o palco se enche de elementos telúricos, que normalmente são ignorados pela nossa visão. Cada dupla começa a apresentar a sua organização de movimento e aos poucos vai saindo do invólucro, ficando um corpo deitado no chão, preso ao corpo do outro dançarino que está em pé, por meio de faixas elásticas. Saem do palco, arrastando o corpo-teia.

Pela diagonal, entra uma dançarina que puxa uma grande prancha rolante com mais uma dupla de corpos-invólucros. Os dançarinos que estavam nos casulos-aéreos sentam-se na faixa e começam a apreciar os movimentos que ocorrem no chão; ao mesmo tempo, a iluminação imprime no palco imagens de espirais/caracóis em movimento. A dançarina Teresa Taquechel puxa a prancha rolante e começa a girá-la enquanto as duas dançarinas, Cláudia Pacheco e Renata Souza, que estão sentadas, começam a livrar-se do tecido que reveste seus corpos.

Ao contrário de uma mutação, como ocorre com a lagarta ao transformar-se em borboleta, os corpos se revelam nas suas singularidades e, como 
um sistema dinâmico, as alternâncias de controle/descontrole dos movimentos voluntários e dos espasmos presentes nos movimentos da dançarina Renata Souza se desvelam e contaminam o corpo da outra dançarina. $O$ foco de luz colocado no centro da prancha enfatiza a expressividade do movimento, as transições e interações pertinentes a esses dois corpos, que, como um corpo duplo, estão interligados em suas relações com o ambiente e, assim, dialogam agem/reagem e se afagam. Tereza Taquechel arrasta a prancha pelo espaço, as espirais vão sumindo e elas saem de cena.

É importante frisar que na pesquisa de movimentos realizada pela Pulsar o foco é a singularidade de cada corpo. Essa preocupação é uma constante na fala da coreógrafa:

Sempre me encantou esses corpos diferentes porque eles geram qualidades de movimento diferentes. Então, por exemplo, um braço de [Rogério] tem uma qualidade de peso; a gente pode ver que é um defeito, mas é qualidade! A primeira vez que eu vi, que eu percebi isso no Rogério fiquei encantada, falei "perai" Rogério repete isso, eu quero isso, [...] essa singularidade. Quando você vê essa singularidade através da arte, através de uma composição coreográfica isso gera um movimento interessantíssimo e, muitas vezes eu aproveito essa qualidade pra gente, [andantes], também aprender. (Taquechel, 2005)

[...] eu acredito também que não pode ficar só nas facilidades. Eu acho que o desafio é fundamental para as pessoas se sentirem motivadas e é o desafio que puxa coisas novas. Também não vou ficar só supervalorizando [referindo-se as qualidades do movimento dos corpos com deficiência], mas eu acho que as coisas existem, que você pode valorizar sim, o que é muito interessante, não precisa negar isso. A qualidade de peso de uma perna que você manipula [a gente trabalha muito com processo de manipulação]; como é manipular uma perna que tem peso específico, que não é ativa, como é que isso se dá, como é que você pode trabalhar esse peso, onde esse movimento vai gerar um outro movimento [...]. (Taquechel, 2005)

A observação da qualidade de movimento do corpo com deficiência é um dos aspectos centrais presentes na coreografia Pulsar. Na continuidade da cena anteriormente descrita, voltam ao palco quatro dançarinos andantes arrastando os corpos-teias até que soltam os elásticos, que atavam um corpo ao outro, e os abandonam no chão. 
As dançarinas das faixas, que estão de cabeça para baixo, escorregam vagarosamente e deitam no chão. Os dançarinos deitados em supino se locomovem no chão com pequenos movimentos sinuosos da coluna, enquanto os outros retornam ao palco com diferentes formas de se arrastar.

Todos estão deitados de costas, alguns com pernas estendidas e relaxadas, e outros com as pernas e braços semiflexionados, assumindo a posição de um bebê deitado, a qual é similar à posição corporal do cadeirante no chão.

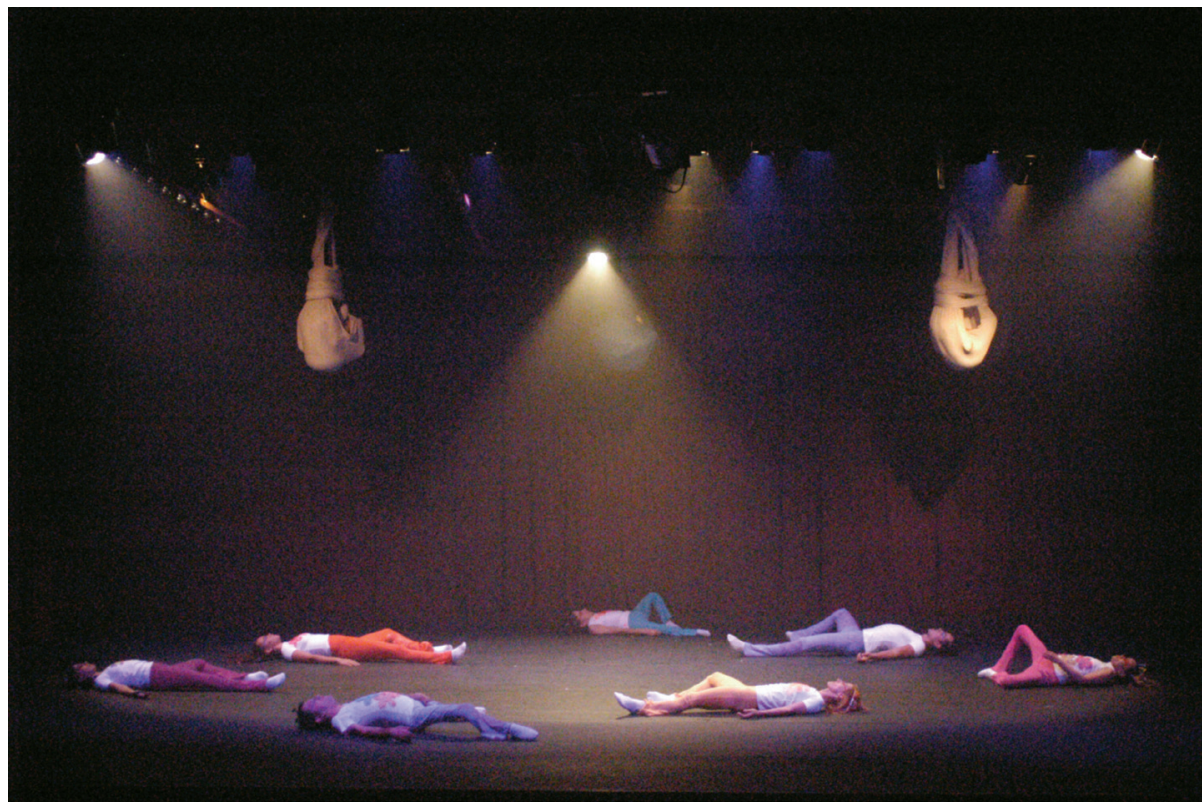

Figura 9. Coreografia Haploos (c). Pulsar Cia. de Dança. Foto de Mauro Kury.

A forma adquirida por esses corpos no chão evoca em minha memória uma foto de W. Eugene Smith denominada O banho de Tomoko (I 972). Essa foto em preto e branco estampa uma mãe com um olhar complacente e afetuoso, banhando o corpo nu de sua filha Tomoko Uemura.

Essa jovem de 16 anos está em uma espécie de ofurô, que abarca seu corpo, com os braços e pernas semiflexionados. Ela é cega e possui o corpo deformado, com atrofias nas pernas, nos braços e no tronco, em decorrência da poluição/envenenamento de mercúrio ocorrida na sua cidade natal Minamata, no Japão. 
Envolta no ambiente acolhedor da água, a foto estampa a relação de contingência de conter e ser contido, o contraste entre a paralisia corporal e a sensação de dor presentes no corpo de Tomoko e a forte relação corporal e afetiva presente no olhar de sua mãe.

Ao contrário do estado de suspensão presente na foto, os corpos em cena nos apresentam metáforas construídas a partir da diferença instaurada nos próprios corpos.

Nessa cena, surgem pequenos focos de luz e cada dançarino(a) começa a sacudir seu corpo no chão e, a partir de movimentos da bacia e dos ombros, a explorar impulsos de movimentos que citam estados corporais, como as ações reflexas, presentes no desenvolvimento neural de uma criança. São seis dançarinos que estão no palco e conjuntamente começam a executar uma sequência, cujo predomínio de qualidades de movimentos é a dos corpos dos dançarinos não andantes.

Simultaneamente, eles conduzem/manipulam o movimento de cruzar uma perna, explorando o peso desse membro; realizam transferências de peso do corpo da posição deitada para sentada a partir do apoio de cotovelos, antebraços e pulsos; sentam com as pernas flexionadas e exploram as oscilações de peso a partir da percepção da base nos quadris e das mudanças de pontos de apoio, aliadas a variações espaço-temporais, tudo feito de forma muito fragmentada. A realização desses movimentos distancia-se de uma simples mecanização e apresenta uma profunda conscientização de suas ações.

A busca pelas qualidades de movimentos de um corpo com deficiência não é algo comumente esperado pelos próprios dançarinos com deficiência, como pode ser percebido na fala de Rogério Andreolli:

[...] eu filmava cada cena que eu fazia na faculdade, depois eu ia pra casa, decupava cada cena e aí eu comecei a detectar que existia uma coisa que eu convencionei chamar de qualidade tetraplégica do movimento, ou seja, uma coisa meio sem jeito de fazer as coisas, que eu procurava até anular, cortar, botar de lado [...]. [Já na Pulsar] o que me encantava naquele momento era exatamente como o meu movimento podia ser útil pra companhia. Naquele momento, aquele jeito meio sem jeito de atender 
o celular era interessante para outra coisa, para uma dança, entendeu. Uma coisa que eu passei durante todo o tempo da faculdade limpando [... . . (Andreolli, 2005)

Em uma entrevista concedida a um jornal on-line (MENDES, 2006), Rogério Andreolli coloca que inicialmente "não gostava da ideia de explorar algo que considerava feio. $O$ deficiente tem uma forma de se movimentar diferente, e eu buscava adequar o meu movimento ao mais próximo, digamos, da normalidade". Ao narrar sua experiência na Pulsar, esse dançarino enfatiza que "foi a primeira vez que alguém manifestou interesse pelo que era genuíno do meu movimento, utilizando-o como matéria-prima para a criação".

A supremacia da normalidade aponta a dificuldade que um dançarino com deficiência pode enfrentar para encontrar em seu próprio corpo qualidades de movimentos, que, para muitas outras pessoas, principalmente aquelas presas à idealização do corpo, estariam mais próximos do dis/forme e do grotesco.

Além disso, esses depoimentos novamente apontam as lacunas existentes no ensino da dança para/com corpos diferenciados, e que somente uma mudança paradigmática do que é dança e corpo pode abrir espaços para caminhos mais profícuos de pesquisa de movimento.

Voltemos à análise da cena. Sentados e colocados diametricamente no meio do palco, cada dançarino começa a explorar o deslizar, giros e transferências de peso. Voltam a realizar conjuntamente uma sequência de movimentos de manipulação das pernas e transferência do peso do corpo para frente, lados e atrás, usando as mãos, pulsos e outros apoios.

Esses movimentos são realizados de uma forma decomposta, o que possibilita ao público perceber o circuito do movimento no corpo. Em seguida, deitam no chão de costas e voltam a explorar o sacudir. Essa sequência é repetida umas três vezes e, apesar de aparentemente ser realizada em conjunto, ela permite revelar o Si da repetição deleuziana. Os dançarinos sentam, cruzam as pernas e criam um movimento de locomoção a partir da alternância do movimento de empurrar a crista ilíaca para frente e para trás. Saem do palco, seguidos por dois dançarinos que ainda têm atrelado aos seus ombros os corpos-teias. 
A segunda coreografia Diploos, com 24 minutos de duração, apresenta, como o próprio nome sugere, relações duais. A coreografia inicia com uma música mais lenta, que cria uma ambiência melodiosa e lírica. Entram em cenas duas duplas, sendo que uma dançarina está sentada sobre as costas da outra, numa posição invertida de uso da cadeira de rodas. Há um rastro demarcado no chão, cortando a diagonal direita até o fundo do palco, dando prosseguimento a outra linha que acompanha a rotunda. Elas deslizam pelo palco e em determinado momento cada dupla pára em uma das metades do palco.

O corpo de Andréa Chiesorin está acoplado ao de Fernanda Rocha e o de Teresa Taquechel ao de Beatriz Monteiro. A dançarina que está em cima do corpo da outra escorrega lentamente em direção ao chão e mergulha seu tronco por debaixo do encosto da cadeira. A cadeira é inclinada e cada dançarina apóia as costas de sua parceira sobre a sua própria. Fernanda Rocha e Beatriz Monteiro, cada qual em sua cadeira de rodas, fazem movimentos de braços, com diferentes mudanças de posições do corpo na cadeira; a cada investida desses movimentos, deixam o peso dos braços ceder e abandonam o movimento, enquanto a cadeira é impulsionada pelo espaço pelas outras dançarinas.

Em um último impulso dado na cadeira, as dançarinas Teresa Taquechel e Andréa Chiesorin deitam no chão. Sem música, as duas dançarinas, que estão na cadeira de rodas, passam sobre o corpo de suas respectivas parceiras, demarcando a sua trilha. Começa a ser tocada a segunda música, que quebra o clima anterior ao explorar um andamento mais rápido. Os dançarinos em cadeiras de roda circulam pelo fundo do palco, enquanto a dançarina Andréa Chiesorin inicia uma sequência de movimentos na qual usa alavancas e mescla movimentos ativos e passivos, o que gera outros impulsos e qualidades de movimentos.

Em seguida, Teresa Taquechel também realiza a mesma célula de movimentos com Chiesorin, só que de forma acelerada. As quatro dançarinas, conjuntamente, repetem várias vezes movimentos que evidenciam o tornar ativo e passivo de braços, tronco e pernas. As duas dançarinas cadeirantes voltam a circular e só Andréa Chiesorin e Teresa Taquechel continuam exe- 
cutando a sequência, cada qual em seu tempo. As dançarinas cadeirantes aproximam-se de suas parceiras, acoplam novamente seus corpos em torno da cadeira e se locomovem, como um só corpo, até a coxia.

A próxima música demarca a entrada de outros dois duos. Andréa Chiesorin é empurrada na cadeira de rodas por Teresa Taquechel, enquanto Fablício Erivaldo carrega Rogério Andreolli em suas costas. Cada dupla direciona seu olhar para a outra dupla. Taquechel manipula o corpo de Andréa Chiesorin usando suas articulações, enquanto esta observa atentamente a outra dupla.

Rogério Andreolli é colocado no chão; ele veste botas pretas e um macacão curto que expõe suas finas e semiflertidas pernas, as quais normalmente são ocultadas no cotidiano. Andréa sai da cadeira e segue Teresa Taquechel em direção à coxia; a cadeira é ocupada por Erivaldo, que senta e passa a observar, juntamente com a plateia, o corpo de Rogério Andreolli no chão. Nesse momento, Rogério Andreolli começa a explorar, por meio de manipulações, movimentos em suas próprias pernas: mostra a amplitude de sua abertura, cria impulsos, levanta a perna e lança-a ao chão, balança as pernas a partir de movimentos gerados pelos quadris, beija seu pé. Contrariando a expectativa da norma, ele torna ativo o que aparentemente se espera ser passivo: o baixo ventre de uma pessoa com paraplegia.

Teresa Taquechel retorna ao palco e por trás de Erivaldo começa a tentar bloquear a atenção/apreciação sobre o corpo do dançarino Rogério Andreolli. Erivaldo reage, desvencilha-se do movimento de Taquechel e continua a mostrar seu interesse pelos movimentos criados pelo dançarino que está no chão: levanta-se da cadeira e vai em sua direção. Começa nesse momento uma manipulação no corpo de Rogério por meio de alavancas com as mãos ou os pés, explorando a imobilidade/mobilidade da sua coluna.

A cada toque, empurrão, puxão, toque com os pés, o corpo aparentemente frágil de Andreolli mostra-se pronto para apresentar suas configurações de movimentos. Erivaldo carrega Andreolli, vira-o de ponta cabeça, o traz para seu colo e balança seu corpo, ativando movimentos em suas pernas. Vagarosamente, Rogério Andreolli rola pelo chão a partir do impulso gerado pelos pés de Erivaldo. 

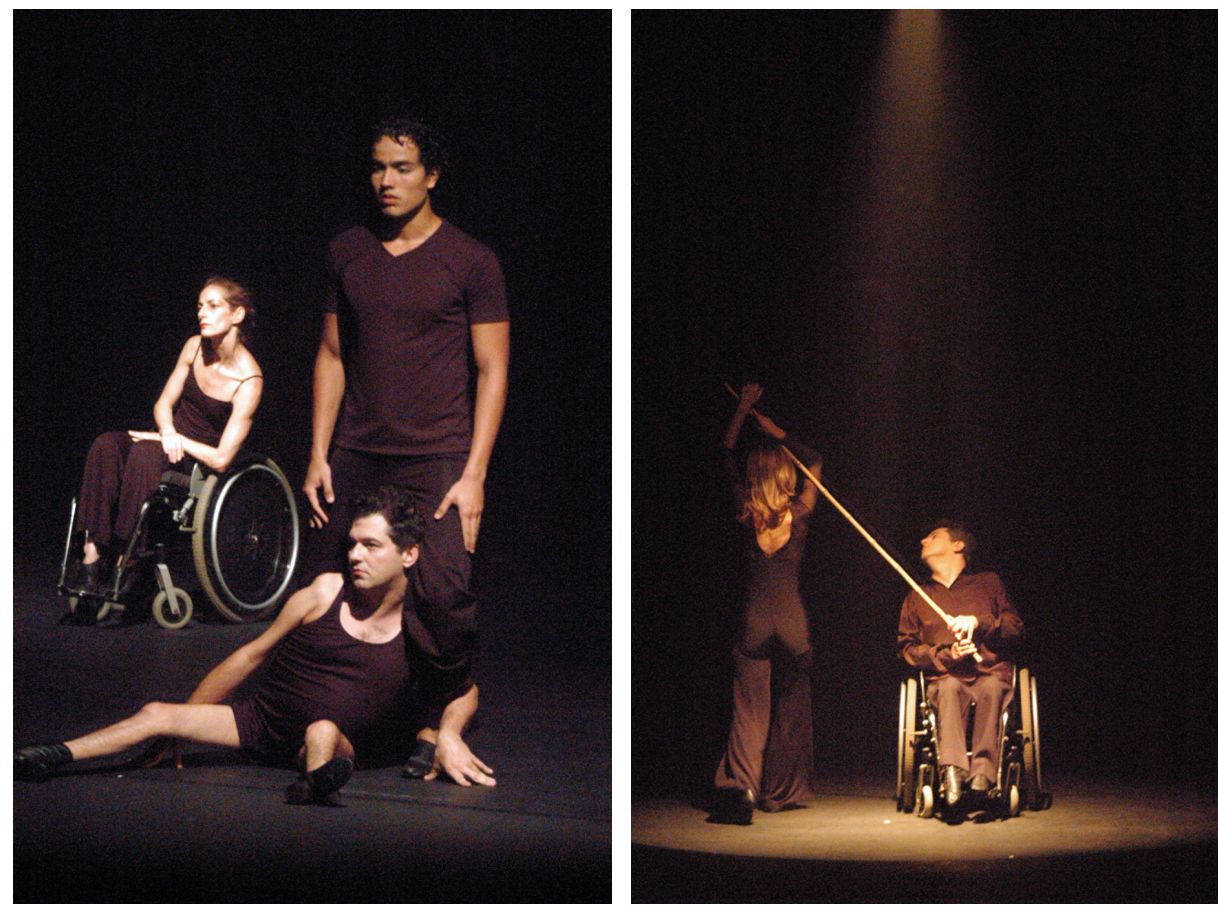

Figuras 10 e I I. Coreografia Diploos (a) e (b). Pulsar Cia. de Dança. Fotos: Mauro Kury

O primeiro inverte o domínio e puxa o outro dançarino para o chão e começam por meio de contatos a explorarem impulsos, equilíbrios e desequilíbrios. Erivaldo volta à cadeira de rodas e Andreolli continua a expor/ compor seus movimentos. No final, Erivaldo carrega Rogério Andréa para a cadeira de rodas e Teresa Taquechel retorna ao palco e o retira da cena.

Em seguida ocorre um duo entre Andréa Chiesorin e Erivaldo que, por meio dos impulsos, equilíbrios e desequilíbrios, exploram formas de interação e locomoção no chão. Os dois também estão impregnados de qualidades de movimentos do corpo dos cadeirantes, o que pode suscitar dúvidas na plateia sobre suas reais fisicalidades. Entretanto, o importante aqui é perceber que nesses corpos flutuantes, cujas identidades multifacetadas navegam nos fluxos oriundos das trocas de informações, são geradas novas paisagens corporais. 
Os dois dançarinos atravessam a lateral do palco até que progressivamente vão descolando do chão e explorando, por meio da contact improvisation, os pontos de contatos, equilíbrios e desequilíbrios.

$\mathrm{Na}$ última cena, Andreolli volta ao palco - desta vez sentado na cadeira de rodas e com uma grande vara de bambu - conduzindo os movimentos de Tereza Taquechel no seu entorno, tornando-se, nesse momento, o controlador das relações de movimento, espaço e tempo estabelecidas no corpo da dançarina. Em um momento, eles largam o bambu e realizam - movimentos, os quais alternam os papéis de estar como manipulador/manipulado. No final, pegam o bambu e como num teste de forças giram em torno de si próprios, contendo e sendo contidos pelo poder do outro.

Considero essa parte da coreografia como uma das mais interessantes para o propósito desta investigação. Nela se instauram, de uma forma muito clara, relações de poder através do ver/ser visto, conduzir/ser conduzido, manipular/ ser manipulado, agir/ter reação. Ao jogar a condição do spectatore, daquele que observa, para dentro da cena, Taquechel possibilita um duplo viés do olhar: o daqueles que estão nesse espaço para a apreciação - a plateia - e o dos próprios dançarinos sobre as singularidades presentes na própria cena.

$\mathrm{Na}$ dança, o olhar exerce um importante papel, já que ele é um elemento fundamental na percepção da experiência somática e na apreciação, seja através das sensações produzidas no próprio corpo quando se assiste a um espetáculo de dança, seja pelas percepções do meu corpo e do corpo do outro quando em movimento. (MATOS, 1998)

Ao tirar de foco o olhar narcisista do dançarino e direcioná-lo ao outro, à alteridade, Taquechel remete essa cena ao espaço do entre. $O$ trânsito de informações estabelecido entre os diferentes corpos - na cena e com a plateia - permite que se perceba, num viés deleuziano, que as repetições travestidas são desveladas, diferindo a diferença. Apesar da coreografia Pulsar enfatizar muito mais as qualidades presentes no corpo do dançarino com deficiência, os processos generativos presentes nessa criação abrem um fértil terreno para que nas próximas criações haja um maior intercâmbio entre as informações presentes nos corpos dos dançarinos com e sem 
deficiência, o que gerará ressignificados na relação do eu com o outro e ampliará os rizomas desses novos territórios estéticos, que surgem na dança contemporânea brasileira.

\section{Grupo X de Improvisação em Dança}

O Grupo Xis ${ }^{16}$, fundado em 1998, é fruto das investigações tecidas pelos coreógrafos e professores da Escola de Dança da UFBA, Fátima Daltro, conhecida no meio artístico como Fafá Daltro e David lannitelli. Inicialmente o projeto se estruturou como um projeto de extensão permanente e depois passou a ser um grupo independente.

Fátima Daltro é licenciada em dança, mestre em artes cênicas pela UFBA, e em 2005, era doutoranda da PUC-SP. Atua desde 1994 na Escola de Dança da UFBA. O professor David lannitelli é americano, com formação na área de comunicação (rádio e cinema) e mestrado em coreografia, ambos pela Temple University, e contribuiu com o Grupo X no período de 1998 a 2002. A parceria desses dois professores surgiu a partir do interesse de ambos nos processos de criação coreográfica e a contact improvisation. ${ }^{17}$

O Grupo X, até 2002, não possuía elenco fixo, pois era composto por alunos de graduação da Escola de Dança e da comunidade externa, sendo aceitas pessoas com ou sem nenhum referencial de dança, o que favoreceu que emergisse, assim, uma pluralidade de corpos em cena. Um dos objetivos iniciais do grupo visava a explorar as possibilidades poéticas do corpo que improvisa e o caráter único de cada apresentação, a partir da improvisação de contato. Para Fafá Daltro, o contact improvisation é

[...] uma dança no aqui e agora. Algo está acontecendo naquele instante, sua realização é viva, autônoma e original. A empatia entre os parceiros da dança é alimentada pelo auto-conhecimento. Quanto mais conscientes estivermos acerca de nossos próprios movimentos e das emoções que são transmitidas por eles, mais facilmente poderemos perceber e entender os impulsos recebidos do parceiro. (UFBA, 2004) 
Esses aspectos também são enfatizados por Steven Paxton, criador do contact improvisation. Para ele, essa técnica de improvisação alia a comunicação de dois ou mais corpos através do contato, dos sentidos, das percepções, da exploração do peso corporal e das relações estabelecidas com a gravidade. No processo de improvisar, acontecem escolhas e o intérprete inventa a sua partitura no processo de interagir e decifrar as improvisações do parceiro.

No livro Choreographing difference, Ann Cooper Albright (1997) explana que o contact improvisation - quando realizado com dançarinos com e sem deficiência - redefine o corpo na dança e revela a possibilidade de podermos olhá-lo como um corpo em processo, o que chamo de um vir-a-ser. Nesse sentido, a ênfase dada pelo grupo na inserção de diferentes singularidades não se restringe apenas à questão da inclusão de um dançarino com deficiência, como é o caso do dançarino cadeirante Eduardo Oliveira - Edu O., que iniciou sua carreira no grupo Sobre rodas...? e, desde 1998, vem se aprimorando como dançarino.

A perspectiva adotada pelo $X$ faz com que a singularidade de cada corpo, explorado na improvisação em cena, gere uma estética própria, baseada na especificidade da fisicalidade do corpo que dança, como, por exemplo, o corpo alto, com longas pernas e braços do bailarino Hugo Leonardo; a maturidade expressiva e artística de Fafá Daltro; a rapidez de Jamille Antunes; e a mobilidade muito particular do corpo de Edu Oliveira.

A entrada de Edu O. no universo da dança através do Sobre rodas...?, em 1997, deu-se em decorrência da continuidade da investigação feita pela coreógrafa Rita Spinelli, no curso de especialização em coreografia da Escola de Dança (UFBA). Essa coreógrafa foi uma das pioneiras na pesquisa da dança contemporânea com dançarinos com e sem deficiência em Salvador.

Nesse grupo, havia uma preocupação com o preparo técnico, com foco no alongamento, dos três dançarinos com deficiência física, principalmente por eles estarem se aproximando da dança pela primeira vez. Foi por meio dessas atividades que Edu Oliveira começou a perceber as potencialidades do movimento de seu corpo e, posteriormente, passou a frequentar as oficinas de contact improvisation realizadas por David lannitelli e Fafá Daltro, o que culminou em sua entrada no Grupo X.18 
Em seu depoimento, Edu Oliveira narra que nunca fez aulas em estúdios de dança e o que ele conhece como técnica de dança é a improvisação de contato e o pilates, técnica esta que o ajudou no condicionamento físico.

Por outro lado, é interessante salientar que Edu O., na maioria das coreografias, dança a maior parte do tempo fora da cadeira de rodas e explora as possibilidades de movimentos do seu corpo demonstrando uma grande mobilidade, tanto com a cadeira de rodas, como fora dela, além de uma consciência corporal refinada. Para esse dançarino, apesar de considerar a cadeira de rodas como extensão do seu corpo - já que ela é usada para sua locomoção e facilitar seu dia a dia - na pesquisa coreográfica ele prefere explorar as possibilidades de seu corpo sem a cadeira, já que esta, em muitos momentos, restringe os movimentos.

A partir de 2003, o Grupo Xis, com a direção coreográfica de Fafá Daltro, muda o perfil do seu elenco, passando a ser formado por dançarinos profissionais de diferentes faixas etárias (entre 18 e 50 anos), tendo como elenco fixo os dançarinos Hugo Leonardo, Edu Oliveira, Fafá Daltro, Juliana Rocha, Jamille Antunes e a participação de dançarinos convidados, como Clênio Magalhães. Além dos dançarinos, o grupo conta com uma contribuição contínua de artistas de outras áreas, como a cantora Andréa Daltro e o músico Ricardo Bordini.

Com essas mudanças, o grupo passa a adotar apenas a letra $X$ para a sua identificação. Na proposta delineada para essa segunda fase, eles mantêm a exploração da improvisação em cena e têm como foco a "investigação e análise das possibilidades e potencialidades do movimento e processos de criação em dança”,(Grupo X, 2005) sendo destacada "a poética do corpo dançante."(Daltro, 2005)

Nesse contexto, apesar do $X$ apresentar-se como um grupo de dança contemporânea, encontrei em alguns releases e programas referências à dança inclusiva, seja através do uso dessa nomenclatura e de outras, como portadores de cuidados especiais, ${ }^{19}$ ou cadeirante, termo este destinado para a identificação do dançarino Edu O., no programa do espetáculo O canto de cada um. 
$\mathrm{Na}$ entrevista realizada com o grupo em 2005, ao indagá-los sobre a adoção do termo dança inclusiva e de todos os seus desdobramentos, a diretora e os dançarinos foram enfáticos em afirmar que preferem ser identificados como um grupo de dança contemporânea e que o uso dessa nomenclatura algumas vezes entrou em projetos na tentativa de obtenção de recursos financeiros destinados para a área de inclusão.

Ao mesmo tempo, o dançarino Edu salienta que se sente incomodado com o uso desse termo, por ser um enorme guarda-chuva. Nas suas palavras, quando um grupo "tem dançarino deficiente, é dança inclusiva. Então não se preza a qualidade da dança, do movimento, do artista. Basta ser deficiente, botar no palco, todo mundo está lá, chorando, achando lindo". Por outro lado, apesar de não gostar dessa nomenclatura, Edu ressalta que há também um caráter político e social na adoção desse termo, em decorrência das barreiras sociais que as pessoas com deficiência enfrentam no seu cotidiano. Como exemplo prático, ele cita que quando participava do grupo Sobre rodas...?, o projeto Quarta que dança ${ }^{20}$ rejeitou a proposta de apresentação da coreografia do grupo por achar que as pessoas poderiam ficar chocadas ao verem muitos "deficientes" no palco. Esse quadro foi revertido em 2004, quando o $X$ apresentou-se nesse mesmo projeto como um dos grupos selecionados.

Outro exemplo citado por Oliveira refere-se ao período em que já fazia parte do $X$. O grupo havia sido convidado por uma empresa de telefonia para se apresentar em um de seus eventos. Somente após a elaboração do convite é que a empresa ficou sabendo que Edu O., um dançarino com deficiência, fazia parte do grupo. Isso foi motivo para que a empresa, de uma forma preconceituosa, descartasse a participação do grupo.

Abordando ainda a questão da inclusão, mais especificamente no cotidiano do Grupo $X$, os entrevistados enfatizaram que Edu não é o foco do grupo e que, mesmo quando ele ou qualquer outro dançarino se ausenta dos ensaios, a rotina não é quebrada. Para a diretora, a entrada de Edu no $X$ não foi com a intenção de se captar uma pessoa com deficiência para o grupo, mas, ao contrário, ele se apresentou como um dançarino interessado no contact improvisation. 
Como o grupo sempre explorou corpos múltiplos, a participação de Edu trouxe contribuições significativas, já que o $X$ se interessa pelo corpo dançante como "um corpo que dialoga com as coisas que estão ao seu redor; como ele mantém as relações com o ambiente, com a situação daquele momento, a capacidade de cada um". Dessa forma, o grupo não tem como foco "a capacidade do contorno da deficiência do Edu" (Daltro, 2005).

Para favorecer uma maior integração entre seus dançarinos, o grupo mantinha uma regularidade de três encontros semanais, intensificados no período final da montagem. É interessante assinalar que cada dançarino era responsável pelo seu preparo técnico, realizado fora do horário de ensaios. Como a maioria era estudante da Escola de Dança da UFBA, eles faziam aulas práticas na graduação, as quais eram acrescidas de outras técnicas, que refletiam interesses pessoais como capoeira, pilates e dança contemporânea, dentre outras. Somente Edu Oliveira não cursava a Escola de Dança, e utilizava seu fazer cotidiano como artista plástico (formado pela UFBA) e arte-educador como preparo corporal, aliado às parcas atividades de fisioterapia e de pilates.

Nas questões da entrevista que giraram sobre o treinamento corporal, o grupo salientou ser necessário o treinamento para que se possa ter qualidade na performance artística, já que a improvisação pede um estado de prontidão que precisa de atenção, confiança e de afinidade entre os corpos, para que se possa estabelecer, com os erros, acertos e acasos, "uma rede nas relações de movimentos”, (Daltro, 2005) que visa a não deixar nenhum dos corpos dançantes numa "zona de conforto." (Leonardo, 2005)

Além disso, tanto Fafá Daltro, quanto Hugo Leonardo ressaltam que a improvisação precisa desse treino, pois ela exige alguns princípios para que o movimento saia com a ideia que se quer transmitir.

Os entrevistados salientaram que, no início do processo dos ensaios, o qual é denominado pela diretora como ensaios-aquecedores, o treinamento estava presente, já que exploravam princípios da dança contemporânea e da improvisação e, nessa estética escolhida pelo grupo, a improvisação é o próprio treino para a percepção do outro. 
Nos ensaios realizados pelo $X$, que incluíam jogos e brincadeiras, o grupo aproveitava ao máximo os elementos e ideias geradas pelo improviso, mesmo que fossem esbarrões, atropelos ou histórias pessoais. A constância das apresentações de improvisação em cena foi outro fator positivo ressaltado pelo grupo para proporcionar a afinidade e a confiança entre os bailarinos e a disponibilidade de criar com o outro. Acrescido a isso Fafá Daltro (2005) comenta que na improvisação em cena em grupo

[...] a gente tem que estar em dois mundos ao mesmo tempo. No seu mundo de performance que você tem que criar, acreditar e fazer o movimento vir poético e estar [também] com o seu corpo olhando pra os outros corpos que estão ao seu redor. Você nunca está só.

É interessante ressaltar que, ao abordar questões sobre o processo de criação e a estrutura dos espetáculos, o grupo salienta que, no início do processo de criação, não há uma ideia totalmente estruturada e que, aos poucos, os elementos vão se organizando, criando uma coesão interna. Além disso, dois aspectos foram apontados como elementos de permanência nos espetáculos. Um refere-se à trilha sonora, a qual é assinalada como um “colchão”, que apóia o processo de improvisar, e o segundo aspecto remete a padrões variáveis de movimentos.

Abordando especificamente o espetáculo $O$ canto de cada um, a diretora coreográfica narra que, no processo de pesquisa, foram surgindo alguns padrões de movimentos, os quais demarcaram apenas o esqueleto de algumas cenas, mas, que, por alguma questão, no momento da apresentação poderiam acabar não acontecendo da forma esperada e, nesse momento, o dançarino precisa ser oportunista e aproveitar o movimento da forma como ele vem.

Além disso, por assumir um duplo papel como diretora e dançarina-criadora, Fafá Daltro (2005) observa que se coloca sempre em estado de alerta para evitar que a performance se perca. Em suas palavras: 
Muitas vezes [...] quando estou dançando em cena e vejo que o momento está andando para aquela parte do 'minhocão', em que todo mundo está fazendo a mesma coisa que não dá em nada, sabe, e entra aquele caos total. Aí eu, geralmente, saio do grupo faço algumas coisas explosivas pra poder desvincular e desmanchar aquele padrão que está levando a performance pra baixo. Na improvisação acontece muito isso; a gente tem que estar muito atento ao que está fazendo.

Esse estado de prontidão necessário no contact improvisation resulta na disponibilidade do dançarino para perceber os sentidos do corpo, o controle corporal, a energia, o fluxo do movimento e o contato corporal e visual com o seu parceiro. Assim, vários exercícios propostos por essa técnica de improvisação visam a aumentar a "percepção de vigília - ou watching your attention (observando sua atenção) - como estratégia de afinação entre o dançarino, seu próprio corpo e o grupo". (IANNITELLI, 2000, p. 66)

Esses aspectos trazem uma diferença prática e conceitual em relação a outras abordagens de improvisação, que a encaram como um processo de liberação de movimento, como um verdadeiro laisse faire, sem nenhuma intencionalidade. Essa perspectiva tem contribuído para um entendimento mais complexo do que é improvisação.

Ao analisarem o processo de criação do espetáculo $O$ canto de cada um, algumas noções-chave do seu processo de criação são apresentadas pelo grupo. As ideias geradoras do espetáculo foram lançadas pela diretora sem que a mesma explicitasse suas intenções pessoais, visto que muitas vezes suas ideias foram desestruturadas e transformadas pelas respostas dos dançarinos-criadores. Algumas vezes surgiram estruturas de movimentos que foram designadas posteriormente para algumas cenas específicas. Essas cenas passam a ter aqueles padrões variáveis de movimentos, o que acaba gerando "uma taxa de conservação, que dá unidade ao espetáculo." (Leonardo, 2005) Como diretora coreográfica, Fafá Daltro assume o papel de conectar as partes estruturadas pelos dançarinos-criadores no processo da pesquisa, retirar os excessos e deixar aquilo que ela e o grupo, em comum acordo, consideram importantes para uma configuração mais significativa da poética do trabalho. 
As singularidades de cada corpo que dança e as relações que são estabelecidas entre esses corpos também são outros fatores ressaltados pelo grupo. Tanto Hugo Leonardo, como Edu O., narram que a adaptação é mútua entre os corpos, o que leva a um conhecimento das qualidades de movimentos específicas de cada dançarino, e esse é um elemento essencial na criação. Como exemplo, o dançarino Hugo Leonardo acrescenta que alguns movimentos gerados nas improvisações em cenas, como um duo realizado entre ele e Edu, só foram possíveis entre eles: "não é possível com mais ninguém; ainda, radicalizando, só era possível naquele momento."

Esses aspectos salientados pelos dançarinos-criadores retratam a importância da singularidade do corpo e o caráter único de cada apresentação. Algumas cenas exploram tanto a especificidade dos corpos que dançam, emergindo uma poética tão específica no momento em que ocorre a improvisação de contato, que fica sem sentido pensar em outra pessoa executando os mesmos movimentos. Este não é um tipo de "coreografia” a ser reproduzida por outros corpos; se isso ocorresse geraria, provavelmente, outra poética e outra qualidade de movimentos, que poderiam ser completamente diferentes da proposta inicialmente explorada.

No que tange à especificidade do corpo, Edu O. ressalta que algumas pessoas que passaram pelo grupo, no início, mantinham certo "receio" em trabalhar com a sua aparente "fragilidade" corporal. Queriam instruções de como pegar, em que parte tocar, o que fazer. Esses receios aos poucos foram sumindo, principalmente a partir do momento em que a pessoa permitia experimentar o movimento, o que gerava, por exemplo, a percepção do peso do corpo do outro e de suas qualidades de movimento. Hugo Leonardo salienta que, quando o grupo já está integrado, como o elenco de 2005 , todos se sentem à vontade em lidar com a especificidade do corpo de Edu Oliveira. Além disso, esse dançarino afirma que na pesquisa coreográfica "não devemos anular nenhuma parte, valorizando outra; dançando exerço minha completude nas questões físicas, existenciais e psicológicas; não saberia menosprezar nenhuma delas. Minha dança é um exercício político." (Oliveira, 2005) 
Como observadora de ensaios e apresentações, considero que a esse fator deve ser acrescentado o dado de que Edu O., como dançarino, está frequentemente em estado de disponibilidade, pronto a explorar os limites e possibilidades de movimentos do seu próprio corpo e deste em relação a outros corpos. Nesse sentido, Oliveira afirma: "eu me considero um dançarino e quero ser criticado como tal, não porque tenho uma deficiência; se meu trabalho tiver qualidade, me elogie, se estiver ruim, diga que está muito ruim pra eu tentar melhorar a minha dança, não a minha deficiência."

Esse aspecto também é salientado por esse dançarino no que se refere à percepção da plateia. Para Edu Oliveira, em seu caso específico, a maioria da plateia ainda se apega primeiramente à questão da deficiência. Todavia, ele ressalta que o Grupo $X$, exatamente por não ter o foco na deficiência, acaba assumindo um importante papel ao favorecer a que a plateia aprecie múltiplos corpos dançantes e, assim, reeduque seu olhar para a dança. Por outro lado, ele menciona que se sente fracassado como dançarino quando, por exemplo, após a apresentação ouve comentários de pessoas que falam que se comoveram ou choraram ao vê-lo em cena, sendo que a coreografia apresentada explorava aspectos da comicidade.

A postura desse dançarino revela a presença de um corpo político na dança, engajado com a questão da diferença. Na concepção de Wolff (1997, p. 96, tradução nossa) qualquer corpo político "deve falar sobre o corpo forçando/acentuando sua materialidade e sua construção discursiva e social, ao mesmo tempo como disruptura e subversão dos sistemas de representação existentes."

Nesse sentido, para Albright (1997), o corpo com deficiência nega ser embrulhado como uma metáfora linguística e, para a pessoa com deficiência, a dança torna o corpo visível na representação de si próprio, não ficando assim dentro de uma ou de outra categoria, mas fica inbetween (dentro do entre), na fronteira. Já Kuppers (2003) ressalta que enquanto para a sociedade majoritária o conceito de deficiência é visto como um discurso secundário (periférico e relacionado ao anormal), para as pessoas com deficiência a deficiência não é secundária, ela é a normalidade da 
própria pessoa e suas experiências são incorporadas, ambas, como primária e secundária ao mesmo tempo, uma experiência vivida que resiste às estruturas linguísticas e, no caso de dançarinos, pode refletir também no processo de criação.

No que se refere à apreciação do público especializado de dança e dos críticos, os entrevistados salientam que o espetáculo 0 canto de cada um tornou-se um divisor de águas para o grupo e que os colegas da área enfatizam agora muito mais a qualidade artística da obra do que a questão da inclusão do dançarino com deficiência. No que tange à crítica especializada, o grupo lamenta que os poucos críticos de arte que existem em Salvador sequer publicaram qualquer comentário sobre o espetáculo, mesmo tendo sido um trabalho premiado em 2003 pelo Projeto EnCena, da Fundação Cultural Gregório de Mattos, realizando oito apresentações em Salvador e ainda uma segunda versão, com trechos do espetáculo e workshops, apresentados na Europa (Ilha da Madeira e Lisboa, em Portugal, e La Seyne Sur Mer, na França). Somente dois comentários verbais - positivos - foram realizados por especialistas da área. ${ }^{21}$

Apesar de considerarem profissional o resultado artístico do grupo, seus componentes enfatizam que as condições de trabalho os colocam também como um grupo mambembe e amador, pela falta de apoio e de recursos financeiros. A diretora frisa que o que promove a permanência do grupo são os subsídios próprios do grupo, ou seja, "as nossas vontades e os nossos desejos, e o espaço da Escola de Dança no qual a gente trabalha. É a única coisa que a gente tem".

Na perspectiva dos integrantes do $X$, a política cultural da área de dança, prevalente até 2005, valoriza a execução de mega projetos, o que implica a quase inexistência de editais para grupos pequenos, seja para manutenção ou montagem. Esse é um dos motivos que levou o grupo a tentar recursos em editais relacionados à inclusão social, sendo a maioria deles ofertados pela área de educação ou assistência social.

Outro dado ressaltado pelo grupo refere-se ao enfoque prioritário da produção artística de dança no eixo Sul-Sudeste. Com isso, grupos de outros Estados têm uma presença menor ou praticamente nula na mídia 
nacional, o que dificulta o reconhecimento de importantes produções artísticas que vêm sendo feitas fora desse eixo.

Considero que, a despeito de todas as dificuldades encontradas pelo grupo, sua produção artística vem sendo cada vez mais reconhecida. A improvisação em cena, da forma como é abordada pelo Grupo X, leva os bailarinos a apresentarem seus corpos como eles são, isto é, valida a noção do eu-sujeito proposto por Morin (1996), pois cada corpo apresenta uma paisagem corporal específica, na qual estão enredadas a "história da espécie, a história pessoal" (GREINER, 1999b, p. 68) e esses referenciais passam a ser os pontos de conexão das ações e retroações do próprio espetáculo.

Assim, os dançarinos-coreógrafos aguçam sua consciência, propriocepção e demais sentidos, já que a fisicalidade/expressividade do corpo que dança é o ponto central da cena. Nesse sentido, cada um está no todo e o todo está em cada um no processo de ser coreógrafo-dançarino. Isso nos leva a perceber que os princípios organizadores e estruturais que são eleitos por cada corpo em cena partem de suas singularidades e diferenças somáticas e culturais, e isso possibilita que possam estar na dialogia das partes com o todo e do todo com as partes, rumo à composição da obra em cena.

Aliado a essas características do trabalho de improvisação em cena, o papel da emoção é um dos aspectos a serem apontados na análise do espetáculo "O canto de cada um". É importante ressaltar que o espetáculo foi visto, por duas vezes, em diferentes espaços teatrais,e a análise aqui a ser apresentada baseia-se, centralmente, no registro em vídeo, e não serão consideradas as variáveis existentes na improvisação em cena observadas em cada apresentação in loco.

\section{Cantos}

O espetáculo $O$ canto de cada um foi montado no ano de 2003, graças aos recursos obtidos com a premiação do EnCena, projeto municipal de incentivo à dança e teatro vinculado à Fundação Cultural Gregório de Mattos. 
O espetáculo estreou, no dia 19 de novembro de 2003, numa primeira versão, no Teatro Vila Velha, com 55 minutos de duração. O elenco foi formado por Fafá Daltro, Juliana Rocha, Hugo Leonardo, Jamille Antunes e Edu Oliveira, sendo este o único dançarino cadeirante. Foram convidados para essa montagem o dançarino Clênio Magalhães, o músico Ricardo Bordini, a cantora Andréa Daltro e o videomaker Victor Venas.

No processo de criação, o espetáculo foi todo delineado para a especificidade do espaço do Teatro Vila Velha, o que possibilitou uma configuração espacial $^{22}$ não tradicional, favorecendo maior proximidade com a plateia. Como cenário, um enorme desenho de jogo da velha é preso ao chão, o qual parece levitar em muitos momentos do espetáculo.

$O$ canto de cada um se caracteriza por ser um espetáculo de um ato, mas no processo de análise identifiquei 16 cenas, as quais podem ser definidas como elos dramatúrgicos, alinhavados por claras mudanças, assumindo a música um papel de "colchão" do espetáculo, que oferece um sentido de organização estrutural, não significando, porém, uma subserviência do movimento ao estímulo musical.

De uma forma geral, o espetáculo explora o universo das relações humanas e, por meio de um viés lírico, aborda aspectos mnêmicos e volitivos dos sentimentos e das emoções, muitas vezes ocultos nas entranhas da carne. As emoções nessa obra são abordadas a partir da evocação de diferentes imagens, símbolos, percepções e estados corporais. Para Damásio (1996, p. I75) a emoção é um "conjunto de alterações no estado do corpo associadas a certas imagens mentais que ativaram um sistema cerebral". Analogicamente, para a diretora Fafá Daltro, nesse tipo de trabalho desenvolvido pelo grupo não é tarefa fácil,

tomar consciência dos meios e caminhos que nos levam ao coração, com o livre arbítrio para construir poeticamente utilizando a improvisação como elemento facilitador e gerador deste processo [...]. Exige do coreógrafo/dançarino a disponibilidade pessoal para entrar em contato com os poderes criativos e descobrir as infinitas possibilidades de associação que podem acontecer quando estamos emocionalmente envolvidos com a forma de linguagem escolhida. 
Esta tarefa intrigante requer uma boa dose de paciência, muita paixão, identificação, persistência e humor do coreógrafo/dançarino para alcançar seus objetivos de forma clara, transparente e significante. (UFBA, 2006)

Nesse sentido, consideramos que, no espetáculo $O$ canto de cada um, - Grupo X explora a singularidade de cada corpo que dança e suas multiplicidades de estados corporais. Não há uma preocupação pela busca de uma resposta uníssona; repercutem no palco diferentes experiências, sentimentos e inscrições corporais, que dialogam entre si e com o ambiente, gerando novos impulsos e novas configurações compositivas.

O espetáculo inicia com o jogo da velha evidenciado no espaço. Quando a plateia entra, dois dançarinos e o músico já estão em cena. Na lateral do palco, são exibidas imagens do videodança Sinais vitais, feito por Vitor Venas. Esse vídeo mostra cenas do trânsito, filmadas em uma faixa de pedestres, na qual os dançarinos se misturam aos demais transeuntes (enquanto os espectadores ocupam seus espaços na plateia) e "se tornam uma espécie de anjos vagando por lá, como as estátuas, oniscientes dos pensamentos dos transeuntes [espectadores]". (Leonardo, 2005)

Os dois dançarinos permanecem sentados em um dos cantos do palco/ tabuleiro até que o músico, colocado no centro do jogo da velha, aumenta a intensidade do som emitido pelo violino e os demais dançarinos entram em cena. Eles zanzam entre os quadrantes do jogo, num estranhamento coletivo, na tentativa de desvencilhar-se um do outro, até que cada um acha, temporariamente, o seu espaço. As três dançarinas sentam sobre baldes e respondem à melodia do violino apenas com a respiração e pequenos movimentos deslizantes.

Edu Oliveira e Hugo Leonardo respondem completamente ao estímulo do instrumento, realizando locomoções e quedas, como num jogo de perguntas e respostas. $\mathrm{O}$ som parece penetrar nos poros desses dois dançarinos e eles não respondem mais pelo audível, mas pelo cinestésico, com vibrações corporais.

Em certo momento, Hugo Leonardo tenta conter o movimento trêmulo de Edu O. e pega-o no colo, permanecendo ainda um resíduo do tre- 
mor das suas mãos. Edu é carregado até a mesa, onde o dançarino Clênio Magalhães já se encontra, em frente, deitado no chão.

Em volta da mesa os três dançarinos realizam movimentos de passagem e começam a trocar papéis, similares a cartas, cujas mensagens parecem escorrer em seus corpos.

As três dançarinas, Fafá Daltro, Jamille Antunes e Juliana Rocha, que estavam sentadas sobre os baldes, começam a ampliar seus movimentos, dançando cada uma com um colar de bolas e, no jogo do acaso de suas memórias corporais, cada uma cria movimentos de lançar e entrelaçar seus próprios corpos.

A cantora Andréia Daltro entra na cena, sentada na cadeira de rodas, locomovendo-se com os pés apoiados no chão. Enquanto canta, vai passando de uma taça para outras várias bolinhas e, aos poucos, começa a deixá-las cair no chão. As bolinhas continuam caindo pelo palco e as dançarinas realizam um movimento de ir e vir na direção da cantora, dando a impressão de que querem responder a cada queda de uma bola. As três dançarinas se juntam no quadrante do fundo e começam, poeticamente, a criar pontos de contato com o movimento da outra, criando encontros consigo mesmo e com o peso corporal do outro. Elas saem de cena entrando outro dançarino, Clênio Magalhães, que ocupa um dos quadrantes do jogo da velha. foco da cantora passa a ser esse dançarino; ela lança sobre seu corpo mais bolinhas e sai do palco.

Entra uma música que, em determinados momentos, apresenta a frase não claramente articulada, "olhe para mim". Apesar de toda a plateia ter seu olhar totalmente direcionado para o único dançarino em cena, Clênio Magalhães, ele parece procurar um outro olhar, uma outra relação. Ele dança sozinho e mais bolas são lançadas da coxia sobre seu corpo, desta vez, de uma forma contínua e forte. Essa cena é interrompida com um som de bate pés. Aparece Fafá Daltro vestida com asas de anjo, a luz se abre e há cinco objetos colocados em diagonal no palco: duas cadeiras de rodas - uma delas ocupada por Edu O. - e mais três bancos.

Contrapondo-se ao senso comum que afirma que o sexo dos anjos não é discutível e cuja representação é mais próxima ao universo masculino, o 
anjo feminino que rompe a cena, de forma barulhenta e com ar espevitado, quebra o foco sobre Clênio Magalhães e o expulsa da cena. Ao mesmo tempo, começa a bater palmas e busca chamar a atenção dos demais dançarinos que retornam ao palco. Clênio Magalhães volta vestido também com asas e, segurando uma corda, começa a escalá-la derrubando aviõezinhos de papel de suas asas. Já situado num plano superior, flutuando no espaço, inicia uma alternância de movimentos entre andares e corridas, que nos remetem aos movimentos dos desenhos animados.

Edu Oliveira continua sentado na cadeira de rodas, realizando uma sequência de movimentos que envolve braços e tronco. Outros dançarinos começam a ocupar as demais cadeiras e, a cada sentar, repetem a sequência de movimentos gerada por Edu, o que faz com que a cena se torne potencializada pela repetição, num sentido deleuziano, através do deslocamento e do disfarce.

Essa célula de movimento deflagra uma brincadeira, que remete ao jogo das cadeiras, onde esses objetos ficam fixos no espaço e os corpos transitam entre eles. Nesse momento, Edu Oliveira acaba ficando "fora" desse jogo que apresenta uma rápida mobilidade.

Cada vez que a sequência de movimentos tem a interferência da brincadeira, Edu O. permanece em sua cadeira de rodas, fingindo não estar atento, mas uma impaciência é desvelada por um sacudir de mãos, que ocorre enquanto a interferência do jogo acontece.

Fica claro aqui um duplo sentido da cena: por um lado apresenta a clara dificuldade de inserção da pessoa com deficiência física nas brincadeiras dos andantes, caso não seja feita uma adaptação para que outros referenciais de movimento sejam incorporados.

O segundo aspecto refere-se à dupla "função" da cadeira: para a maioria, um objeto feito para sentar, sem necessidade de uma marca pessoal; para alguns cadeirantes ela torna-se a extensão do corpo, seu meio de locomoção, com sua inscrição pessoal.

Assim, como brincar no jogo das cadeiras, nos moldes tradicionais, se esse objeto é a própria marca do caminhar para o cadeirante? Nessa cena, Edu O. opta pela imobilidade/estabilidade da cadeira já que sua particulari- 
dade do "andar", ou seja, sua mobilidade sobre rodas, não foca as pernas como o andante. Há aqui uma outra organização corporal, que causa estranhamento à pessoa sem deficiência.

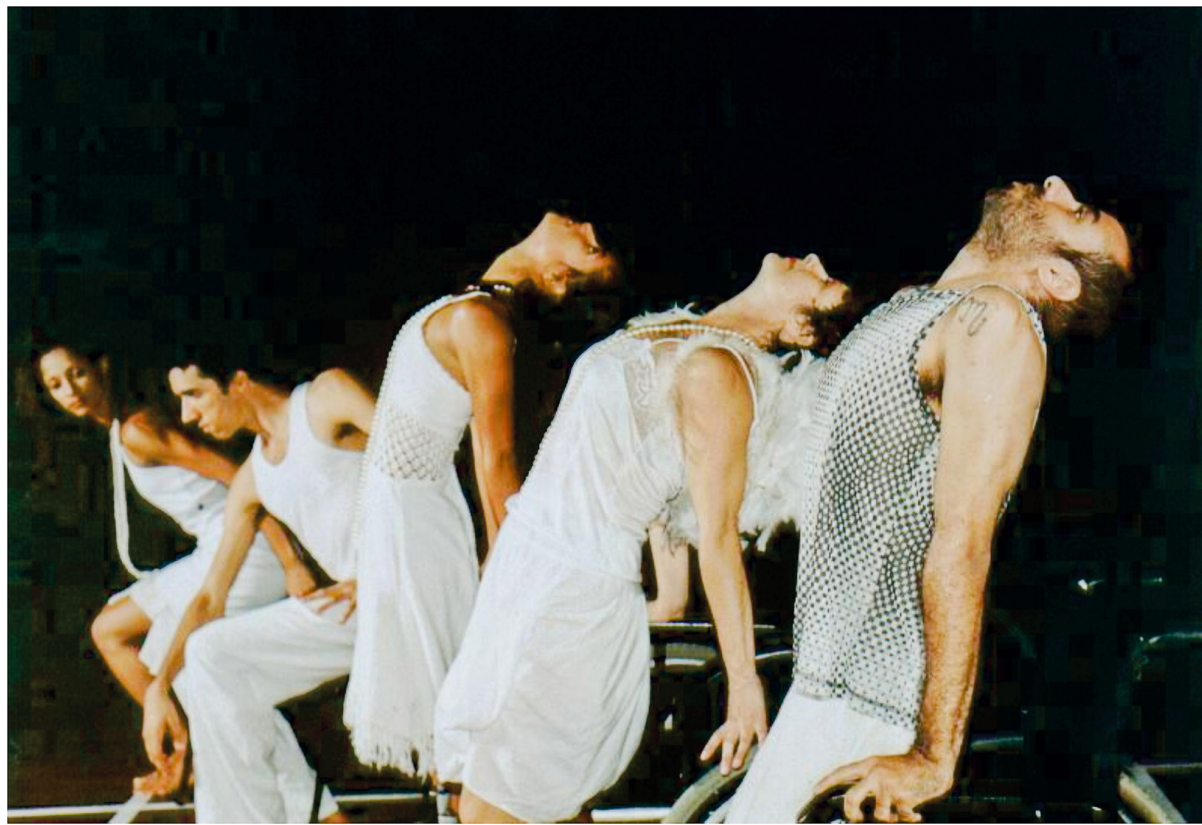

Figura I2. O Canto de Cada um (a). Grupo X de Improvisação em Dança. Foto de Andréa Vianna.

A mesma cena descrita acima dá continuidade com a descida do anjo da corda, e este, sem música, começa a pegar no chão do palco os aviõezinhos que havia derrubado e começa a arremessá-los na plateia. Ao mesmo tempo, Fafá Daltro e Edu Oliveira transitam no palco cada qual em uma cadeira de rodas.

O violinista volta à cena e o dançarino Hugo Leonardo começa novamente a responder corporalmente ao estímulo sonoro, tentando tapar os ouvidos para não ouvir. Acaba vencido pela resposta do corpo e começa a replicar os acordes musicais com movimentos alusivos a passos de dança folclórica e depois a um twist.

Leonardo sai de cena e volta carregando uma das dançarinas, vestida com um tutu preto e botas pretas, e a larga no chão em um dos quadrados do jogo da velha. Mais uma vez ele volta a responder, enfaticamente, 
com movimentos estereotipados, ao comando do violino e fica clara a alusão à existência da repetição na dança como uma repetição de padrões de movimento que estão introjetados na memória corporal, aproximando-se do condicionamento apontado por Skinner em seus experimentos da Psicologia Experimental.

Enquanto esse dançarino atende ao comando da música, a dançarina Jamille, que foi largada no chão, tenta fugir, escondendo-se na plateia, mas, ao perceber essa ação, o dançarino volta a buscá-la, carrega-a e a coloca no mesmo lugar. Nessa cena, percebemos um contínuo fugir versus buscar, estímulo musical versus resposta-padrão de movimento, até que o dançarino interrompe o movimento, cochicha algo para o músico e sai da cena.

Nesse momento, inverte-se a relação. Surge um foco só em Jamille Antunes, que dança explorando o espaço do seu quadrante, procurando dominá-lo e descobrir seus limites, uma parte de cada vez.

Quando a dançarina cai no chão, a luz abre-se para o jogo e, ao mesmo tempo, outros dançarinos caem em outros quadrantes. Nesse momento, começam a surgir, misturados à melodia da música, os nomes dos dançarinos, como num jogo infantil de descoberta de sons, algumas vezes distorcidos, outras vezes reduzidos e transformados numa espécie de mantra, numa autocontemplação. Será o eu de cada um, com suas diferentes identidades desveladas? Chamam a si próprios, remetem-nos às suas singularidades.

Com o ecoar de seus nomes, os demais dançarinos também exploram seus espaços, seus "cantos”, o que é ressaltado pela luz que delimita e mostra cada um em seu quadrante. Esse espaço é totalmente pessoal e ele é ampliado e reduzido conforme as estratégias de seleção de movimentos por eles escolhidas. Aos poucos, iniciam-se interações - vocais e corporais - num sutil compartilhar/disputar do espaço: há abandonos, disputas, afetividades e interações entre os corpos.

Essa cena desemboca na próxima, na qual são abordados trechos do poema Tereza. O poema de Manuel Bandeira (1970, p. I7) principia com um olhar analítico e distanciado de Tereza e, depois de tantos olhares, acaba desaguando em uma paixão surreal. $\bigcirc$ poema diz: 
A primeira vez que vi Tereza

Achei que tinhas pernas estúpidas

Achei também que a cara parecia uma perna

Quando vi Tereza de novo

Achei que os olhos eram muito mais velhos do que o resto do corpo

[...]

Da terceira vez não vi mais nada

Os céus se misturaram com a terra

E o espírito de Deus voltou a se mover sobre a face das águas.

$\mathrm{Na}$ abordagem do espetáculo, trechos desse poema são elementos geradores para um solilóquio conectado com a resposta corporal dos demais dançarinos em cena. Enquanto Hugo Leonardo comenta o tema do poema, os demais dançarinos realizam um "cortejo" em torno da cadeira de rodas, sendo esta empurrada por duas dançarinas vestidas com tutu branco, que exibem sua esbelta e despidas pernas. Outro dançarino adota o personagem de cachorro, um poodle, que se torna - adotando o termo usado no espetáculo - o "nó terapêutico" da cena.

Apesar das pernas das dançarinas - estarem em evidência, com um andar bem feminino de sedução, surge uma referência dúbia. As pernas em questão são mesmo as torneadas pernas das dançarinas ou se aponta também para a deficiência das pernas de Edu, nas quais o público usualmente foca seu olhar? Surge aqui a questão da falta, tão frequentemente relacionada ao corpo do $\underline{\mathbf{d}} /$ eficiente.

Esse sentido dual - a falta e a completude - está presente na leitura realizada pelo olhar normalizador de uma plateia formada, em sua maioria, por pessoas sem deficiência, o que a leva ao confronto com seus reais limites e seu possível devir por meio "do corpo do outro [que] reflete a imagem do meu corpo como num espelho". (GIL, 1994, p. 140) Para muitos, a falta é algo a ser ocultado. Quando se retira o véu da normalidade e surge o corpo dançante da pessoa com deficiência na sua mais crua materialidade, a arte/ dança esgarça as expectativas das normas sociais e revela, no corpo sem fronteiras, a poética da imperfeição. 
Vale ressaltar que na entrevista realizada com o grupo, este sinalizou que, no processo de criação, as pernas em questão referiam-se as da dançarina Fafá Daltro. Esse fato aponta também para uma quebra de modelo do corpo idealizado: a referência é feita às pernas de uma mulher de 50 anos e não as das jovens dançarinas.

Essa cena desmancha-se com a entrada de uma música - um tango - que sugere a interação entre pares, mas, cada dançarino, meio esquizofrenicamente, interage consigo próprio. Nesse mesmo momento, são projetadas novas imagens do videodança, desta vez filmados em uma passarela de rua. Paradoxalmente, nessa cena, apesar de a música sugerir um clima de atração, nos momentos em que ocorrem encontros com outros corpos há diferentes reações: desvios, repulsas, desencontros e interações.

Aos poucos, um corpo começa a seduzir/contaminar o outro, mas, muitas vezes a reação é de combate à invasão afetiva. Os gestos, como os de adeus dado para o vazio, são usados como forma de exagerar-se o sentido social da dança de salão. O único casal que apresenta um clima de sedução é formado pelos dançarinos Edu Oliveira e Fafá Daltro e, assim, ao contrário do que o senso comum tem como expectativa para o corpo com deficiência, nessa cena, esse corpo torna-se um corpo desejado.

$\mathrm{Na}$ cena seguinte, apenas dois dançarinos permanecem no palco e passam de um espaço ao outro, procurando encontrar conexões. Na meia-luz, tateiam o espaço, mas, nada acham; agarram o ar em busca de si próprios e do outro que não está mais. Como coloca Bavcar (2003), o ser humano não pode se ver com seus próprios olhos.

Os dois dançarinos saem de cena e entram outros casais. Tudo fica sinuoso, só há desencontros, falta de apoio. Todos correm pelo espaço e os encontros são novamente de passagem. Afinal, a regra do jogo da velha não é encontrar seus pares para fechar a linha? Uma linha reta que não dá opções de formas, apenas de posicionamento no espaço? Como no próprio jogo da vida, no qual tentamos a todo custo sobreviver até mesmo negando nossa possibilidade mais concreta que é a morte, esse jogo aparenta ser sem fim.

A mesa volta à cena. $O$ foco está nesse objeto e não importa a diferença existente entre os personagens que estão ao redor - um alto, um mediano 
e Edu, sem sua cadeira de rodas, colocado ao lado da mesa, parecendo uma criança ou um anão. Com batidas sobre a mesa, todos disputam; um lance leva a um contra-lance e quem ganha, não ganha nada; todos ganham o movimento. $O$ desafio está na batida, no poder da definição.

Essa cena é interrompida pela entrada de uma cadeira de rodas, que é empurrada vazia para dentro da cena. Edu revela mais uma estratégia de locomoção e vai engatinhando até ela.

$O$ desenho do jogo da velha se transforma num trilho. Duas cadeiras de rodas acompanham esse trilho e deixam as suas marcas simbólicas. Edu O., fora da cadeira, arrasta-se também no espaço e impulsiona sua cadeira com as mãos no chão. Ele interage com a outra cadeira, vazia, apenas travestida com as asas do anjo. Será um anjo da guarda, invisível, sem sexo, corpo e face definida? Ou será então o anjo do progresso apresentado por Benjamin ( 1985), ao abordar sua tese sobre a história? Esse anjo, com as asas abertas, que avança e recua ao mesmo tempo, em direção ao futuro com o olhar conectado ao passado, arrasta tanto as mazelas humanas como os banidos, aqui representado pelo corpo do deficiente. Similar à pintura do anjo de Paul Klee, que "avança recuando", a imagem desse anjo ao mesmo tempo em que evoca a proteção nos oculta os olhares para o espelho da história. (BAVCAR, 2003)

Edu O. abandona a cadeira e, encontrando uma nova possibilidade de estabilidade/locomoção, sai literalmente andando com as mãos apoiadas nos pés e se coloca no canto do jogo. Enquanto isso, Andréa Daltro volta a cantar e um dançarino, na terceira cadeira de rodas, circula ao redor dela, contemplando a obra e a intérprete.

$\mathrm{Na}$ cena seguinte, três chapéus enormes, femininos e elegantes, estão na cabeça de três pessoas sentadas nas cadeiras de rodas, que realizam um balanceio da frente para trás. Esse movimento oscilatório dá uma amplitude ao movimento da cadeira, modificando sua característica de deslocamento linear frontal para a oscilação do símbolo do infinito, passeando livremente pelo espaço.

Os chapéus amplos, com véus, retiram a percepção de gênero dos corpos que ocupam as cadeiras. Esses chapéus nos remetem à obra de Oliver 
Sacks - O homem que confundiu sua mulher com um chapéu -, na qual um dos pacientes desse neurologista, ao tentar pegar seu chapéu, segura o corpo da própria mulher, devido à existência de problemas neurais relacionados à percepção. Analogicamente, neste trecho coreográfico, a proposital confusão de percepção gerada pelo objeto, que leva a uma associação direta com corpos femininos, é demonstrada no momento em que as três pessoas tiram os chapéus e se identificam como homens.

Nesse momento, eles assumem o papel do poder, comumente designado ao sexo masculino, e iniciam uma sutil disputa espacial, que acontece sobre rodas, após cada giro e esbarro lançado no espaço. Nessa cena, mesmo os dançarinos sendo dois andantes e um cadeirante, não há relação hierárquica direta entre dominador/dominado, deficiente/não deficiente. Eles são colocados no mesmo patamar de disputa, inversamente ao que acontece no dia-a-dia de grupos minoritários, como o das pessoas com deficiência, nos quais oslas ditam as regras.

Esses três dançarinos alinham suas cadeiras no lado direito do fundo do palco. Fafá Daltro dependurada em uma corda, "voa" ao redor deles, e os imobiliza, um a um, em cada ação de troca de chapéus, sendo estes, desta vez, masculinos. No lado oposto, uma dançarina deitada no chão preenche de palavras o seu espaço, num contínuo escrever e apagar.

Dois dançarinos saem da cadeira de rodas e começam a explorar modos de andar. É demarcado o andar normal, o com as mãos e o da cadeira. A dançarina continua escrevendo e o foco de luz enfatiza sua ação até que outros dançarinos começam a interferir. Palavras aparecem e são apagadas pelo movimento do seu corpo. Edu Oliveira entra na cena e começa também a apagar as palavras com seu corpo. Ele e Hugo Leonardo iniciam um duo, substituindo o escrever palavras pelo mover-se e conectar-se. Afinal, esses corpos não precisam de palavras, já estão cheios de significados.

As três dançarinas retornam com seus baldes e cada uma ocupa um dos espaços do jogo, sem conseguirem ou quererem fechar a linha do jogo da velha. As três se colocam na parte central do jogo e começam a repetir células individuais de movimento, mas que possuem princípios em comum como peso, suspensão, leveza e força. 
Em seguida, Hugo entra carregando um balde cheio de bolas. Fafá Daltro e Edu Oliveira se locomovem, mudando a oposição espacial, como numa brincadeira de esconde-esconde/sedução, estando aqui em questão a relação emotiva. A dançarina passa de um quadrante ao outro, carregando o balde com bolas e é perseguida pelo dançarino Edu O., até que Fafá Daltro senta e começa a dançar com as bolas entre as mãos, lançando-as no espaço. Simultaneamente, essa ação é projetada em um telão no lado direito do palco, com o foco nas mãos da dançarina. $O$ dançarino tenta freneticamente conter as bolas/afetos e, aos poucos, muda seu estado de corpo para uma sensação de diversão.

Fafá Daltro continua a empurrar/jogar as bolas e Edu Oliveira faz malabarismos, mostrando um controle/descontrole sobre o corpo; por fim, coloca um nariz de palhaço, assumindo uma atitude clown.

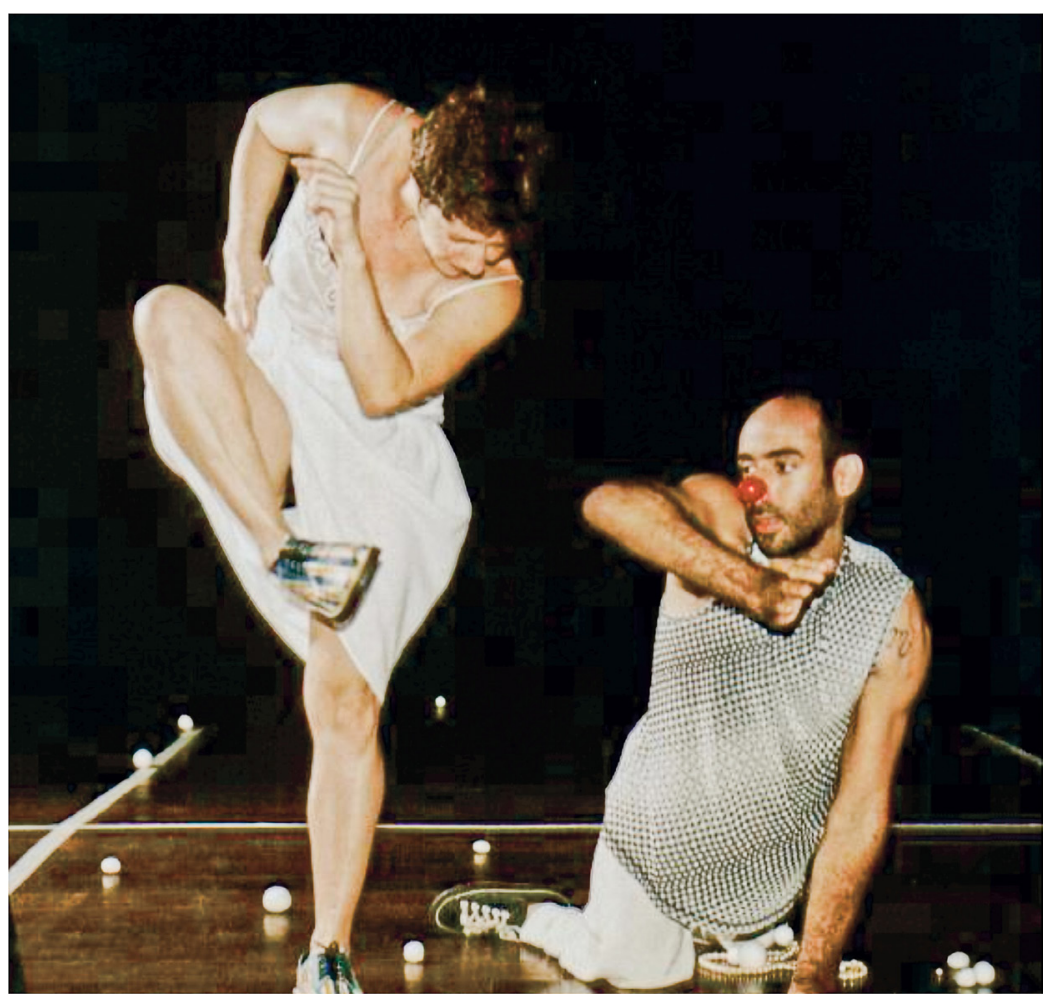

Figura I3. $\bigcirc$ Canto de Cada um (b). Grupo X de Improvisação em Dança. Foto de Andréa Vianna 
Fafá Daltro brinca com Edu Oliveira, fingindo oferecer um balde que acaba não cedendo. Eles se aproximam e começam a interagir, acompanhados por uma música francesa que nos remete a temas circenses. Em alguns momentos, os movimentos de Fafá estão apoiados no corpo de Edu e vice-versa. Acontecem aqui transferências de peso/carícias a partir da improvisação de contato.

Embora o clima clown sugira uma aparente ingenuidade, esta cena transgride a visão da deficiência como passividade. Aqui, Edu Oliveira ri da expectativa dos andantes sobre o seu corpo e sua mobilidade, em decorrência da expectativa da inexistência de movimento de suas finas pernas, sem tônus muscular. Ele cria estratégias, agita suas pernas, mostrando que pode andar sobre as mãos, sustentando seu corpo, brincando com a quebra de limites de seu próprio corpo.

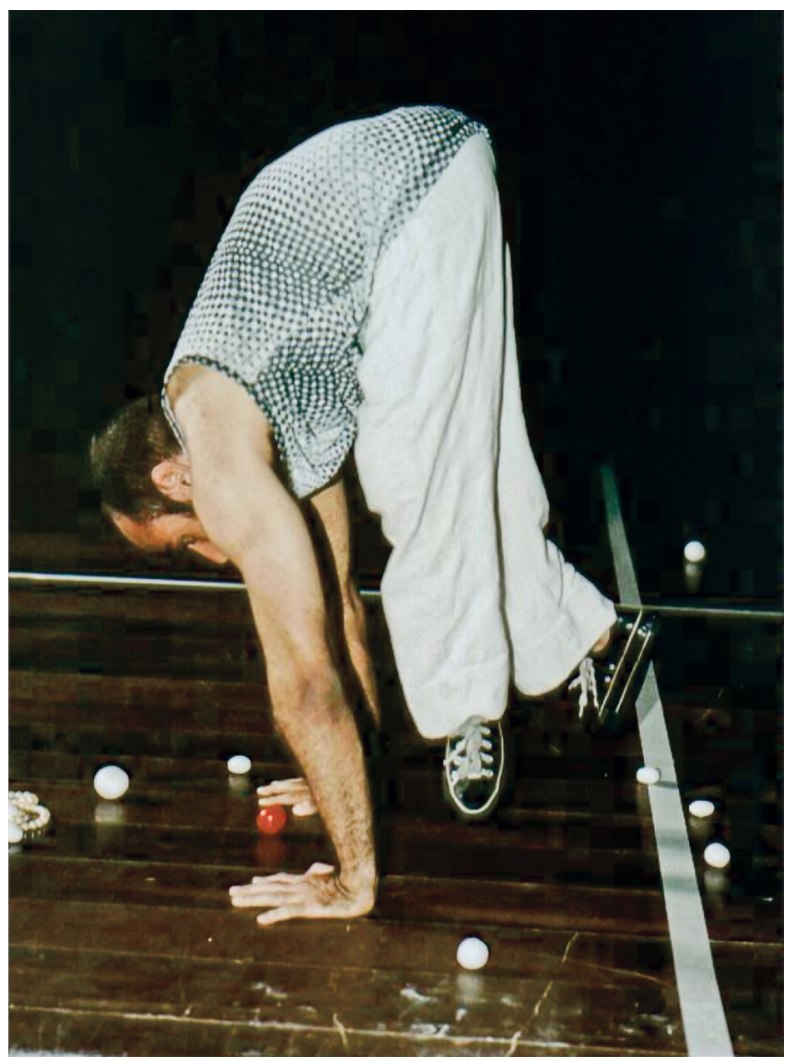

Figura 14. O Canto de Cada um (c). Grupo X de improvisação em Dança.

Foto de Andréa Vianna 
Esse casal de dançarinos continua à frente da cena $e$, ao fundo, alguns casais começam a ser mostrados: discutem, declaram-se, um se entrega ao comando do outro. Fafá e Edu continuam a improvisar, encontrando formas de carregar e arrastar. Seus corpos, em alguns momentos, tornam-se uno.

Volta à cena a estória de Tereza e o cortejo sendo que, agora, Edu Oliveira se junta a Clênio Magalhães para assumir a postura do personagem cachorro (poodle). Hugo Leonardo comanda o monólogo e a direção da locomoção do cortejo. Todos atendem ao seu comando e congelam o movimento na frase: poodle é um saco! Há aí a instauração da brincadeira de estátua, na qual um tema (o poema de Tereza) gera o movimento de cortejo e um refrão - poodle é um saco! - gera a imobilidade.

A cantora que ocupava no cortejo a cadeira de rodas levanta-se e começa a cantar a cantiga Se essa rua fosse minha, tocando os dançarinos, um de cada vez, retirando-os do estado de congelamento. A cantora e o violinista prosseguem até os espectadores e se tornam anônimos na plateia.

A cena é interrompida pela entrada de uma música acelerada, percussiva, e cada dançarino ocupa um espaço no jogo da velha, tentando dominá-lo. A dança é mais energética: rolam, lançam-se de um espaço a outro com a mesma intencionalidade, mas com serenidade. Às vezes, começam a interagir com o outro no mesmo espaço. Todos no mesmo espaço, cada um no seu espaço pessoal. Cada qual em seu canto... Acontecem várias possibilidades de intersecções para o jogo da velha, fecham-se várias combinações, mas este é um jogo sem fim, afinal nossas emoções existem enquanto estivermos vivos. No fim da música, estão todos no chão. Foco no centro do jogo. Ao fundo, o som do violino retorna à cena e os corpos estremecem. Há respostas... "o corpo ainda pulsa". ${ }^{23}$

A análise aqui apresentada da coreografia $O$ canto de cada um, partiu das metáforas emanadas pelos corpos em cena e, a partir delas, abriu-se para que, no processo de interpretar, outras metáforas fossem incluídas. Greiner (2005, p. 48) afirma que o estudo das metáforas, 
Entendidas como metáforas do pensamento, nos ajuda também a compreender que as mudanças de nomeação do corpo, no decorrer de sua história, apontam para questões que seguem além das classificações gerais, destacando também o modo singular como o entendimento do corpo e das suas relações com o ambiente, os sujeitos, a consciência, a linguagem e o conhecimento, vêm sendo rediscutidos e redimensionados.

Sobre esse assunto, Susan Foster em seu artigo Kinesthetic empathies and politics of compassion, de 1998, aponta que o sentido de metáforas na dança pode ser abordado apenas como efeito de um processo de descrever e comunicar uma experiência e a inexatidão desse processo ou, então, de uma forma radical, colocar o corpo como o foco central da dança. Dessa forma, podemos perceber que aprendemos dança com o corpo do outro e experimentamos, simultaneamente, as igualdades e diferenças.

Esse aprendizado possibilita perceber qual tipo de relação é feita a partir do outro e como o poder se move, onde é consolidado e quando é dispersado. Foster (1998, p. 30) ainda enfatiza que o corpo tem que ser privilegiado como foco central da dança e "quando o seu sistema de metáforas desmorona, nós podemos não mais dançar".

Por essa via, as metáforas construídas em "O canto de cada um", tornaram-se essenciais para o entendimento da dança produzida por esse grupo. Nesse espetáculo, o Grupo X, a partir de sua opção pela improvisação em cena como processo de investigação e resultado cênico, alterna, em sua composição coreográfica, estruturas flutuantes e outras rizomáticas e, ao trabalhar a fisicalidade a partir do contact improvisation, faz com que sejam incorporados ao seu trabalho conceitos como singularidade, acaso, associação, desorganização e consciência.

Desse modo, o $\mathrm{X}$, ao explorar os diálogos empáticos com o outro e a alteridade somática de cada um de seus dançarinos, possibilita que o corpo em cena, longe de promover a comoção, apresente ao olhar da audiência o corpo com deficiência em seus próprios termos. Nesse sentido, vale a pena reinscrever as palavras de Edu O.: "Dançando exerço minha completude 
nas questões físicas, existenciais e psicológicas, não saberia menosprezar nenhuma delas. Minha dança é um exercício político”.

\section{Notas}

I Foram enviados formulários por correio e e-mail a instituições e profissionais que trabalham diretamente com pessoas com deficiências. Também foram enviados formulários para Universidades e docentes ligados à formação em Dança.

2 Dados obtidos a partir da auto-identificação de cada grupo ou de dados colocados em programas de espetáculos.

3 Maiores detalhamentos sobre a metodologia da pesquisa de doutorado, ver Matos (2006).

4 Em 2006, a Cia Ekilíbrio apresentou os espetáculos "Sente-se e Sem Nome” em uma mini-temporada no Teatro Cacilda Becker, no Rio de Janeiro. Nesse mesmo ano foi contemplada com o Prêmio "Funarte Além dos Limites". Em 2007, por meio de uma nova pesquisa estreia o espetáculo "Cotidiano Imaginário”, com o qual circula, até 2008, por várias cidades brasileiras. Em 2009, ocorre o falecimento da dançarina Cássia Guedes. Em 2010 o grupo se reconfigura e cria o espetáculo “e agora...”. Atualmente desenvolve uma parceria com a Faculdade de Medicina e de Educação da Universidade Federal de Juiz de Fora (UFJF), na execução de um projeto de extensão. Mais informações no site: www.ekilibrio.art.br

5 No programa do grupo, não consta nenhuma referência aos créditos musicais e, desse modo, só citaremos as músicas pela sua ordem de ocorrência.

6 Adotamos o termo alunos-dançarinos por serem alguns deles amadores, com exceção de Christine Sílmor e Sílvia Renhe, respectivamente diretora e coreógrafa, e do dançarino Ricardo Visciano.

7 Ambos são portadores de retinose pigmentar severa, associada a deficiência intelectual e auditiva. O termo deficiência intelectual vem sendo adotado no lugar de deficiência mental, já que o primeiro termo refere-se "ao funcionamento do intelecto especificamente e não ao funcionamento da mente como um todo" (SASSAKI, 2005). A adoção desse termo também foi sinalizada na Declaração de Montreal sobre Deficiência Intelectual (2004).

8 Esses alunos não possuem deficiência física. Suas dificuldades motoras estão aliadas à deficiência intelectual e afeta aspectos de coordenação motora global. Pela falta de um campo de visão amplo, por causa da retinose pigmentar, eles apresentam dificuldade de locomoção (percepção de distância etc). 
9 Tive a oportunidade de participar desse workshop, cuja proposta inicial era de ser exclusivo para os componentes da Cia. Ekilíbrio. Compartilharam também, como convidados, as atividades desse workshop os dançarinos Edu Oliveira (Grupo X-BA), Rogério Andreolli e Fabrício Erivaldo (Cia. Pulsar - RJ).

10 Gardner (1995) considera a inteligência como uma rede de organizações cerebrais, que podem ser diferenciadas em oito potenciais: linguística, musical, lógica-matemática, espacial, corporal-cinestésica, intrapessoal, interpessoal e naturalista.

I I A Limites continua seu trabalho, tendo apresentado suas coreografias, dentre elas a Disforme, em vários teatros. Em 2007, como comemoração dos 15 anos da companhia, foi produzido o projeto Limites em movimento: registro fotográfico e videográfico, o qual foi selecionado em 2008 pela curadoria do Centro de Criatividade de Curitiba e Soho Gallery de Nova lorque. Em 2009, deu início ao projeto Affordances: proporcionamento do corpo ao ambiente liquido; pesquisa corporal e aproximação do trabalho da Limites com a linguagem da videodanca, apresentando os resultados no Paraná e na Letônia.Em 20I I, a Companhia passa a ser dirigida por Claudia Fantin e Thaís Catharin, contando ainda com o apoio do Centro Cultural Teatro Guaíra e da Associação dos Deficientes Físicos do Paraná. Em 20I I, Andréa Sério assume a direção do Balé Teatro Guaíra.

12 Termo utilizado pelos dançarinos na sua apresentação. Nota-se que no eixo SulSudeste do Brasil há uma grande tendência ao uso da nomenclatura bailarino em detrimento de dançarino, mesmo quando se trata de dança contemporânea. Como possíveis explicações, podem ser consideradas a forte influência do ballet clássico e a busca por uma distinção de status social com outras dançarinas, como as de prostíbulos.

13 Proposta ainda não publicada.

I 4 A Pulsar continua com o apoio do Centro Coreográfico da Cidade do Rio de Janeiro, onde realiza seus ensaios. A Companhia sogfreu pequenas alterações em seu elenco e hoje, além de Teresa Taquechel, Rogério Andreolli, Andréia Chiesorin, Reanata Souza, também conta com a participação de Beth Caetano, Gabriela Alcachofra e Frederico Baptista.Em 2006 estreo o espetáculo "O corpo do outro", coreografado por Alexandre Franco. Em 2008 e 2009 recebe o apoio da Caixa Cultural para a realização do Festival Corpos Ímpares. Em 2010 estreia o espetáculo "Indefinidamente Indivisível”, contemplado no Prêmio FUNARTE de Dança Klauss Vianna. Teresa Taquechel ministra cursos de "Consciência Corporal e Dança" no Teatro Cacilda Becker. Maiores informações: http://www.pulsardanca.art.br

I5 Apesar de o grupo ter sido gerado no âmago da Escola e Faculdade Angel Vianna, nem sempre os ensaios foram realizados lá por falta de disponibilidade de salas. Além disso, a escola e a faculdade funcionam num casarão com diferentes níveis, em Botafogo, o que dificulta o acesso de pessoas com deficiência física e a realiza- 
ção dos ensaios da Pulsar nesse espaço. A escola já tem há alguns anos um projeto de adaptação, mas que depende da obtenção de recursos financeiros para sua concretização.

16 Os primeiros folders do grupo aparecem com essa escrita. Posteriormente, adotaram apenas a letra $X$. O Grupo $X$ continua desenvolvendo suas atividades artísticas, tendo sido contemplado em diversos editais estaduais e nacionais para apoio à montagem e circulação, com espetáculos como "Pequetitas coisas entre Nós Mesmos"(201I,com audiodescrição), "Vestido curto na alma de dentro" (2010) e "Os 3 audíveis- Ana, Judite e Priscila" (2008). Em 2004, inaugura o Projeto Euphorico, objetivando residências artísticas anuais com a Cia Artmacadan (França), parceira essa que se mantém ativa. Organiza em 2010 e 201 I edições do Encontro de Dança Inclusiva, de abrangência nacional, congregando artistas, educadores e pesquisadores interessados nessa temática.

17 Usarei daqui em diante o termo contact improvisation ou a tradução improvisação de contato.

I8 Paralelamente ao trabalho com o Grupo X, Edu participou do grupo Rodarte (2002) e de performances com Clênio Magalhães (2005).

19 Nomenclatura adotada pelo grupo.

20 O Quarta que Dança é realizado no espaço Xisto Bahia, que foi coordenado, nesse período, por Marize Queiroz e Sérgio Sobreira. Esse projeto faz parte das ações desenvolvidas pela Fundação Cultural do Estado da Bahia, no intuito de fomentar a produção coreográfica, o surgimento de novos profissionais e a formação de plateias para a dança.

2 I As especialistas citadas na entrevista são Helena Katz e Dulce Aquino.

22 Apesar do espetáculo ter sido construído para um teatro não convencional, aconteceram posteriormente duas apresentações em palcos italianos: uma no Teatro ISBA, e outra no Espaço Xisto Bahia.

23 Adaptação da frase "o pulso ainda pulsa”, da música $O$ pulso, dos Titãs. 


\section{UMA CARTOGRAFIA MUTANTE PARA TRANSITÓRIAS CONCLUSÕES}

Os entrecruzares realizados no processo investigativo, que resultou neste livro, a partir da polifonia de vozes disseminadas pela análise dos produtos coreográficos, pela voz dos pesquisados, pela abertura das valises de pensamento dos teóricos que acompanharam esta jornada e pela voz da pesquisadora, proporcionaram adentrar por espaços irregulares, na busca de entender a complexidade do fenômeno estudado e sua tessitura na ambiência contemporânea.

Desse modo, consideramos que a ideia de extrapolar terrenos fractais e buscar articulações rizomáticas possibilita, imageticamente, perceber que os aspectos apresentados neste trabalho, a partir de eventos pontuais, servem para desvelar, como uma potente lente de aumento, características topológicas de uma parte do cenário da dança contemporânea, que também se reflete no seu todo e nos seus emaranhados de ações, interações e retroações. (MORIN, 1996) Ao configurar esta cartografia como um mapa mutante, foi possível apresentar alguns descentramentos, disjunções e conjunções presentes, neste momento, no fenômeno estudado. 
Ao rastrear a presença de múltiplos corpos na dança, por meio da articulação de trabalhos coreográficos com dançarinos com e sem deficiência, pode-se primeiramente perceber que esse fato não acontece de maneira isolada, sendo decorrente principalmente da existência de políticas de inclusão social e da busca pelos direitos civis das pessoas com deficiência.

Entretanto, por estarmos em um período de transição, nota-se uma ânsia pela busca de rápidas soluções para o atendimento à proposta inclusiva, o que não deixa de ser necessário dada à falta de atendimento às questões básicas dos direitos civis das pessoas com deficiência. Por outro lado, essas soluções acarretam um desordenamento, desconsiderando-se, muitas vezes, as especificidades, funções e competências profissionais das diferentes áreas de conhecimento que devem contribuir para esse processo.

Trabalhar com pessoas com deficiência na dança não é um sinônimo correlato de terapia ou de ação educativa, como pensam alguns olhares desavisados. Desse modo, faz-se necessário que barreiras sejam quebradas no intuito de garantir, tanto o acesso físico, quanto uma sólida formação artística, para que pessoas com deficiência possam se inserir no mercado e, desse modo, produzirem danças, textos e contextos sobre dança, diferença e deficiência, também como autores.

Enquanto isso não se efetiva na prática, abrem-se caminhos para que espaços destinados à promoção da saúde ou da educação, por exemplo, tentem ampliar seus leques de atuação promovendo, de uma forma ainda assistencialista, o ensino e a produção artística em dança.

Nessas instâncias, muitas vezes, assume o papel de professor de dança ou coreógrafo um terapeuta e/ou professor, despreparado para tal função e com uma ínfima formação e informação do que é dança e arte, mas como "dono do saber" do que é deficiência, coloca-se como o promotor de boas ações para a pessoa com deficiência. Isso faz com que visões estanques sobre dança, corpo e arte, e até mesmo sobre o que é deficiência, sejam perpetuadas: embebem-se esses corpos no paradigma da normalidade através de um disciplinamento corporal e, principalmente, pela exploração de um viés emocional de suas ações. 
Nesse senso comum, dança é movimento e expressão universal, e a abordagem estampada nos trabalhos coreográficos distancia-se do cruzamento cultural, torna-se monofônica, e não explora os elementos constitutivos da dança. Assim, equivocadamente, o corpo como mídia dessa arte é tratado como um instrumento que se direciona para um grande apelo do seu significado emotivo. Ao mesmo tempo, essa perspectiva é uma via em que a inclusão se direciona apenas a uma concessão espacial - e faz com que o próprio estigma da deficiência se dissimule e continue a ressoar em seus corpos-grutas.

A dança inclusiva, como conceito e da forma como vem sendo apresentada no Brasil, inclui pessoas com e sem deficiência na mesma relação espaço-temporal, mas não modifica o pensamento de dança e nem compreende a diferença na alteridade. (DELEUZE, 1998) Esses aspectos, aqui apresentados, tornam-se indícios para que novas investigações sejam feitas nessa área buscando mapear, de uma forma mais ampla, as práticas realizadas no campo dessa chamada dança inclusiva, que aqui prefirimos colocar provisoriamente inclusiva, esperando que, em breve, essa nomenclatura não precise ser mais utilizada.

Por outra via, torna-se importante também pensarmos que é urgente a necessidade de uma inclusão cultural, para que a pessoa com deficiência tenha acesso à produção artística como criador, apreciador e freqüentador de espaços que promovem a difusão da arte. Tais espaços precisam tornar-se acessíveis ao fazer/conhecer arte de modo que acarretem também um pensamento de dança que abarque as diferenças e a possibilidade do artista com deficiência ser um criador, fazendo emergir seus pensamentos em arte. Esse viés da arte/dança, enquanto área de conhecimento, pode e deve também estar presente em espaços educacionais, desde que seja conduzido por pessoas especializadas na área.

Algumas dessas questões acima puderam ser percebidas na análise do $I^{\circ}$ Festival Internacional da Arte sem Barreiras (CONGRESSO, 2002). As produções presentes nessa mostra, em sua grande maioria, apresentaram, nos seus produtos, clichês do que é dança. Por meio de uma visão instrumental da dança e do uso de estereótipos de movimento, essas coreografias repetem, de forma nua, no sentido deleuziano, no corpo com 
deficiência, os padrões de normalidade esperado na dança para um corpo dançante sem deficiência.

Dessa forma, a identidade da pessoa com deficiência é mediatizada pelo padrão de normalidade, cuja representação deixa sua identidade presa ao lugar social (HALL, 1997) e se estabelece então uma clara hierarquia de poder da pessoa sem deficiência sobre a pessoa com deficiência. Além disso, nesse falsa relação de simetria ou de tentativa de conciliação entre contrários - deficiente/não deficiente - busca-se aproximar os corpos dançantes com deficiência do paradigma idealizado de beleza, numa clara associação entre belo e bom, ignorando suas especificidades. (VÁSQUEZ, 1999) Nesse sentido, aflora-se a poética do fragmento, ressaltada por Coli (2002), e busca-se dar um sentido de completude, por meio da adoção de normas estéticas já esperadas em dança, ao que muitos consideram como uma im/perfeição.

Por meio desse viés da dança esconde-se a diferença, e o corpo com deficiência, em exposição, torna-se um corpo errante, sem pertencimento, e inserido em um spetaculum: rompe seus limites, supera sua deficiência, torna-se herói de si mesmo e co/move uma segmentada platéia que espera ser comovida. Dessa forma, os significados contidos nessas danças não promovem aos corpos e identidades se tornarem flutuantes, ficando estes enraizados, presos a um sistema viciado pelas mesmas informações.

Assim, esses corpos são supostamente incluídos, mas, sem conseguirem ultrapassar o limite da fronteira de seus guetos e nem terem voz ativa no processo de construir significações na dança. Nesse viés aqui sinalizado, apesar de percebermos a emersão dos corpos com deficiência na dança, finge-se não perceber suas diferenças, não se reeduca o olhar da platéia por meio do trânsito de novas informações e os corpos dançantes com deficiência ainda continuam acoplados ao que estamos chamando de superfícies dissimuladas.

Por outro lado, é importante sinalizar algumas questões pertinentes à área da dança. Como foi ilustrado por meio de um recorte temático que conectou pontuais eventos históricos, a presença de corpos não-idealizados na dança sempre esteve muito mais relacionada a representações de um grotesco teratológico, abordando aspectos do cômico e do burlesco. Com a dança moderna, o corpo dramaticamente expressivo assume determinados 
aspectos da representação identitária do outro, cujo diálogo se dá no trânsito de informações com o ambiente; todavia, o corpo que o apresenta é o corpo esperado como mídia da dança.

Somente com a incorporação de corpos não-treinados e não-idealizados da dança pós-moderna e algumas produções de dança contemporânea como as de Maguy Marin, Win Vanderkeybus, CandoCo, Grupo X, Pulsar Cia de Dança, dentre outros, é que se pode perceber a perspectiva de diálogos entre diferentes corporalidades, provocadoras de estranhamentos na platéia. Aqui o grotesco crítico afirma intensamente a diferença pelo excesso (DELEUZE, 1998) e desvela ao público o que antes se tentava ocultar.

O panorama feito no segundo capítulo aponta a necessidade de um aprofundamento na pesquisa histórica, a partir do recorte temático da presença do corpo grotesco na dança, perspectiva essa que não foi encontrada no levantamento bibliográfico realizado até 2006.

Outro aspecto a ser salientado refere-se a alguns abalos que começam a despontar nesse cenário, apesar da permanência de superfícies dissimuladas. Esses abalos nos permitem assegurar que reconfigurações territoriais estão sendo delineadas na dança contemporânea. Na cartografia realizada para a pesquisa de Doutorado, foi possível detectarmos pequenas alterações nesse ambiente, nos diálogos estabelecidos em algumas das produções dos grupos aqui analisados, nos quais o corpo assume uma identidade movimentante (CUNHA E SILVA, 1999b), transgride os espaços e difere, criando novas metáforas na dança.

Como um sistema dinâmico e complexo, o pensamento de dança começa a ser reconfigurado pela influência de alguns grupos que trabalham com bailarinos com e sem deficiência, salvaguardando aqui as singularidades de cada grupo. Por meio da produção artística e/ou educativa de grupos como Ekilíbrio, Limites, Pulsar e Xis, pode ser percebido - de uma forma ainda embrionária em dois deles e de uma forma mais sedimentada nos demais que os diálogos desses corposmídias da dança têm possibilitado uma construção estética, que pode assumir um caráter transgressor e crítico.

Assim, esses grupos apresentam em seus produtos a especificidade de cada corpo e as teias de relações que podem ser criadas e pesquisadas, 
criando zonas de estranhamento, de encontros e desencontros. A sensação desse estranhamento é perceptível no ambiente, seja pela reação de uma platéia de leigos ou de especialistas em dança, seja no apagamento da memória dos críticos especializados que, muitas vezes, negam em seus textos espaço para dialogar com a diferença, por puro preconceito ou desconhecimento da qualidade artística desses trabalhos.

Mesmo com a dança contemporânea abarcando corpos heterogêneos, as práticas corporais usualmente presentes nas salas de dança, em sua maioria, ainda se encontram arraigadas a um corpo idealizado. Nesse sentido, para que os treinamentos corporais e os processos criativos não sejam abordados por meio de uma única perspectiva de corpo, a inclusão das pessoas com deficiência precisa ser vista como uma possibilidade de arejamento dessas práticas e de busca por processos generativos de criação em dança que coloquem o corpo e a diferença como focos centrais da investigação, a partir do trânsito de informações presentes nos corpos com e sem deficiência, bem como no ambiente.

Algumas iniciativas começam a ser delineadas pela Cia. Limites e pela Pulsar Cia. de Dança, as quais têm buscado encontrar caminhos metodológicos para o treinamento em dança que, ao abarcar corpos diferentes, não busquem transpor para estes a estrutura do corpo idealizado na dança ou do contexto tradicional do ensino de técnicas corporais.

Este é um profícuo e amplo campo de pesquisa, que abre perspectivas para o acompanhamento de aulas e de processos de criação, no intuito de identificar os processos generativos de práticas que trabalhem com diferentes corporalidades e abarquem conceitos como diálogo cultural, pluralismo estético, alteridade e diferença na dança contemporânea.

A presença da diferença se amplia nas produções contemporâneas internacionais como as do DV-8, CandoCo, DIN A I3, dentre outros, e, no cenário nacional, companhias como o Grupo X de Improvisação em Dança e a Pulsar Cia. de Dança. Tais companhias promovem a incorporação de novos pensamentos em dança, sendo que, nestes casos, os corpos dos dançarinos com e sem deficiência, como mídias de si mesmos, são elementos essenciais para o processo generativo da criação. 
Esse aspecto pode ser também ressaltado na especificidade de cada corpo dançante com deficiência, pois, mesmo nos casos onde o tipo de deficiência é comum a mais de um grupo, como a questão da deficiência física, cada dançarino apresenta sua singularidade, sua concepção sobre ser deficiente e suas estratégias de criação na dança.

Como corpos, espaços e pensamentos nômades, a forma descentrada com que se dá a produção artística desses grupos possibilita que a diferença se instaure nos agenciamentos, na transitividade de informações presentes nesses corpos, gerando processos de desterritorialização e apresentando metáforas construídas no/pelo corpo. Essa perspectiva possibilita perceber que as sínteses disjuntivas instauradas pelo pensamento hegemônico e iluminista, as quais são baseadas na separação e exclusão, podem ser transgredidas por síntesse transitivas, construídas a partir da relação com o outro, com a alteridade, com a diferença, resultando numa relação de pertencimento e numa reconfiguração social, espacial e política. É por esse viés que no pensamento deleuziano o ser se diz na diferença, no Si da repetição.

É nesse sentido que, com esta cartografia mutante, pudemos retroagir ao ponto de origem desta publicação - a investigação desenvolvida no Doutorado e, com um olhar atento sobre o processo de conhecer, apresentar algumas conclusões e lacunas pertinentes àquela investigação. Assim, apresentamos nestas linhas possibilidades relacionadas à ambiência da dança e do corpo na contemporaneidade, a partir dos diálogos estabelecidos entre corpos de dançarinos com e sem deficiência na dança, tendo como eixo norteador o conceito chave da diferença presente no pensamento de Gilles Deleuze.

Desse modo, podemos, na transitoriedade desta conclusão, afirmar que algumas produções de dança contemporânea com dançarinos com e sem deficiências têm possibilitado a instauração de novos pensamentos na dança contemporânea. Esses pensamentos do corpo vêm provocando um deslocamento de territórios na dança, e por meio dessa pluralidade movimentante fissuras são instauradas, anunciando novas configurações territoriais e corporais na dança contemporânea brasileira, baseadas na poética da im/perfeição. 



\section{REFERÊNCIAS}

ALBRIGHT, Ann Cooper. Choreographing difference. Hanover: Wesleyan University Press, 1997.

AMARAL, Lígia Assumpção. Sobre crocodilos e avestruzes: falando de diferenças físicas, preconceitos e sua superação. In: AQUINO, Júlio Groppi (Org.). Diferenças e preconceito na escola: alternativas teóricas e práticas. São Paulo: Summus, 1998. p. II-30.

ANIMATED. Magazine of the Foundation for Community Dance. London, spring, 2002.

ASSMAN, Hugo. Paradigmas educacionais e corporeidade. Piracicaba: UNIMEP, 1995.

AUSLANDER, Phillipe.; SANDHAL, Carrie. Bodies in commotion: disability and performance. Michigan: Michigan Press, 2005.

BAKTHIN, Mikhail. A cultura popular na Idade média e no renascimento: o contexto de Rabelais. São Paulo: HUCITEC, 1993.

BALLET TANZ. Berlim, n. 55092, nov. 2001.

BANDEIRA, Manuel. Tereza. In: . Estrela da Vida inteira. Rio de Janeiro:

Olympio, 1970.

BANES, Sally. Terpsichore in sneakers. Boston: Houghton Mifflin, 1980. 
BANES, Sally. Writing dancing in the age of postmodernism. Hanover: Wesleyan University Press, 1994.

BARNES, Colin. Disability studies: what's the point? In: THEORY, POLICY AND PRACTICE CONFERENCE. . Anais... Lancaster: University of Lancaster, 2003. Notes of a verbal presentation at the Disability Studies. Disponível em <http://www.leeds. ac.uk/disability-studies/archiveuk/archframe.htm >. Acesso em: fev. 2005.

BARTALOTTI, Celina. A Terapia Ocupacional e a atenção à pessoa com deficiência mental. O Mundo da Saúde: revista do Centro Universitário São Camilo, São Paulo, ano 25 , v. 25 n. 4 , out./dez. 200 I.

BAUER, Martin, GASKELL (Ed.) Pesquisa qualitativa com texto, imagem e som: um manual prático. Petrópolis, RJ: Vozes, 2002.

BAVCAR, Evgen. O corpo, espelho partido da história. IN: NOVAES, Adauto. O homem-máquina: a ciência manipula o corpo. São Paulo: Cia das Letras, 2003.

BENJAMIN, Adam. Making an entrance: theory and practice for disabled and nondisabled dancers. London: Routledge, 2002.

BENJAMIN, Walter. Magia e técnica, arte e política. São Paulo: Brasiliense, 1985. (Obras escolhidas, I v.).

BIANCHETTI, Lucídio. Aspectos históricos da apreensão e da educação dos considerados deficientes. In: BIANCHETTI, L.; FREIRE, Ida. Um olhar sobre a diferença: interação, trabalho e cidadania. Campinas, São Paulo: Papirus, 1998.

BORDO, Susan.; JAGGAR, Alison M. Gênero, corpo e conhecimento. Rio de Janeiro: Record; Rosa dos Tempos, 1997.

BOURCIER, Paul. História da dança no ocidente. São Paulo: Martins Fontes, 1987.

BROWN, Peter. Corpo e sociedade: o homem, a mulher e a renúncia sexual no início do cristianismo. Rio de Janeiro: Jorge Zahar, 1990.

CENTRO COREOGRÁFICO da Cidade do Rio de Janeiro. Disponível em: http:// centrocoreografico.blogspot.com/. Capturado em 2 fevereiro de 2006.

COLI, Jorge. O fascínio de Frankstein. Folha de São Paulo, São Paulo, jun. 2002. Caderno Mais 2, p. II.

CONGRESSO INTERNACIONAL DE ARTES SEM BARREIRAS, I.; FESTIVAL ARTES SEM BARREIRAS, I., 2002, Belo Horizonte. Anais... Belo Horizonte: PUC- MG, 2002.

CROCE, Arlene. Discussing the undiscussable. The New Yorker. New York, p. 55, 26 dez. 1994.

HUGO, Vitor. CROMWELL: tradução do prefácio de Cromwell. In: . Do grotesco ao sublime: tradução do prefácio de Cromwell. São Paulo: Perspectiva, 1988, 90 p. 
CUNHA E SILVA, Paulo. O corpo que dança: uma abordagem bioestética do movimento. In: TËRCIO, Daniel (Ed.). CONTINENTES EM MOVIMENTO. O Encontro de Culturas na História da Dança. Actas. Cruz Quebrada, PT: Faculdade de Motricidade Humana, 1999a. p. 23-26. Piaget, 1999b.

O lugar do corpo: elementos para uma cartografia fractal. Lisboa: Instituto

DALY, Ann. Classical ballet: a discourse of difference. In: DESMOND, Jane (Ed.). Meaning in motion: new cultural studies of dance. Durhan: Duke University Press, 1997, p.III-II9.

DAMÁSIO, António R. O erro de Descartes: emoção, razão e o cérebro humano. São Paulo: Companhia das Letras, 1996. . O mistério da consciência. São Paulo: Companhia das Letras, 2000.

DEL PRIORE, Mary Lucy M. A história do corpo e a nova história: uma autópsia. Revista USP, São Paulo, n. 23, p. 48-55, set./out./nov. 1994.

DELEUZE, Gilles. Diferença e repetição. Rio de Janeiro: Graal, 1988.

DESMOND, Jane C. (Ed.). Meaning in motion: new cultural studies of dance. Durham: Duke University Press, 1997.

DINIZ, Débora.; MEDEIROS, Marcelo. Envelhecimento e deficiência. Disponível em: $<$ http://www.anis.org.br/serie/visualizar_serie.cfm?ldSerie=42>.Acesso em: 25 jul. 2004.

ESCOSTEGUY, Ana Carolina. Estudos Culturais: uma introdução. In: SILVA, Tomáz Tadeu (Org.). Identidade e diferença: a perspectiva do Estudos Culturais. Petrópolis: Vozes, 2000.

FERNANDES, Ciane. Escrevendançando: teoria e prática na pesquisa em artes cênicas. In: Bião, Armindo et al. (Org.). Temas em contemporaneidade, imaginário e teatralidade. Salvador: GIPE-CIT; São Paulo: Annablume, 2000a, p. 229-246.

. Pina Bausch e o Wuppertal Dança-Teatro: repetições e transformações. São Paulo: HUCITEC, 2000b.

. Transgressões em Harmonia: Algumas Contribuições Brasileiras à DançaTeatro de Rudolf Laban. LOGOS - Comunicação e Universidade: revista da Faculdade de Comunicação Social da UERJ, Rio de Janeiro, ano I0, n. I8, 60-8I, semestral, 2003.

FONTES, Maria. Corpos canônicos e corpos dissonantes: uma abordagem do corpo feminine em oposição aos padrões corporais idealizados vigentes nos meios de comunicação de massa. 2004. 222 f. Tese (Doutorado em Comunicação) Faculdade de Comunicação, Universidade Federal da Bahia, Salvador, 2004. 
FONTES, Maria. Um outro corpo em cena: a deficiência física sob a lógica do espetáculo. 1999. I 40 f.Dissertação (Mestrado em Comunicação). Faculdade de Comunicação, Universidade Federal da Bahia, Salvador, 1999.

FOSTER, Susan. Corporealities. New York: Routledge, 1996.

(Ed.). Dancing bodies. In: DESMOND, Jane C. (Ed.). Meaning in motion: new cultural studies of dance. Durham: Duke University Press, 1997.

. Kinesthetic empathies and politics of compassion . In: TÉRCIO, Daniel (Ed.). CONTINENTS IN MOVIMENT, - O encontro de culturas na História da Dança, 1998. Lisboa. Atas... Lisboba: Gráfica 2000; Faculdade de Motricidade Humana, 1999. p.27-30.

FOUCAULT, Michel. Vigiar e punir: nascimento da prisão. Petrópolis: Vozes, 1987.

FRACTAIS. In: HOUAISS, Antônio; VILLAR, Mauro Salles. Dicionário Houaiss da Língua Portuguesa. Rio de Janeiro: Objetiva, $200 \mathrm{I}$.

FUNDAÇÃO NACIONAL DE ARTES. Ministério da Cultura - FUNARTE- MINC. PROGRAMA Arte sem Barreiras. Notícias. 2005. Disponível em: <www.funarte.gov. br>. Acesso em: 21 dez. 2005.

FUNDAÇÃO NACIONAL DE ARTES. Ministério da Cultura - FUNARTE- MINC. PROGRAMA Arte sem Barreiras. Notícias. 2006. Disponível em: <www. funarte.gov. br>. Acesso em: 25 maio 2006.

FRALEIGH, Sondra Horton. Dance and the lived body. Pittsburgh: University of Pittsburgh Press, 1987.

FRALEIGH, Sondra; HASTEIN, Penelope (Ed.). Researching dance: envolving modes of inquiry. Pittsburgh: Pittsburgh Press, 1999.

GARDNER, Howard. Inteligências Múltiplas: a teoria na prática. Porto Alegre: Artes Médicas, 1995.

GIL, José. Metamorfoses do corpo. Lisboa: Relógio D’água, 1997. Monstros. Lisboa: Quetzal, 1994.

GOFFMAN, Erving. $O$ estigma: notas sobre a manipulação da identidade deteriorada.

Rio de Janeiro, RJ: Guanabara, 1988.

GREEN, J.; STINSON, S. Postpositivist research in dance. In: FRALEIGH, Sondra; HANSTEIN, Penelope (Ed.). Researching dance: envolving modes of inquiry.

Pittsburgh, Pa: University of Pittisburgh Press, 1999. 368 p.

GREINER, Christine. O corpo: pistas para estudos indisciplinares. São Paulo: Annablume, 2005. 
GREINER, Christine. Corpos em crise, uma in-tradução. Revista Repertório: Teatro \& Dança, Salvador, ano 2, n. 2, p. 7-II, semestral 1999a.

. A cultura e as novas dramaturgias do corpo que dança. Cadernos do GIPE-CIT: Grupo Interdisciplinar de Pesquisa e Extensão em Contemporaneidade, Imaginário e Teatralidade, Salvador, n. 8, p. 65-70, dez. 1999b.

. A dança e seus novos corpos. Repertório: Teatro \& Dança. Salvador, ano 7, n. 7, p. 54-63, semestral 2004.

. Por uma dramaturgia da carne: o corpo como mídia da arte. In: Bião, Armindo et al.(Org.). Temas em contemporaneidade, imaginário e teatralidade. São Paulo: Annablume; Salvador: GIPE-CIT, 2000, p. 353-364.

GREINER, Christine; AMORIM, Cláudia (Org.). Leituras do corpo. São Paulo: Annablume, 2003.

; KATZ, Helena. Corpo e Processo de Comunicação. Revista Fronteiras: estudos midiáticos, São Leopoldo, RS, v. 3, n. 2, dez. 2001.

. Por uma teoria do corpo-midia. In: GREINER, Christine; AMORIM, Cláudia (Org.). Leituras do corpo. São Paulo: Annablume, 2003.

GUATARRI, Félix; RONILK, Suely. Micropolítica: cartografias do desejo. Petrópolis, RJ: Vozes, 1993.

. Caosmose: um novo paradigma estético. São Paulo: Editora 34, 1992.

HALL, Stuart. Quem precisa de identidade? In: SILVA, Tomáz T. (Org.). Identidade e diferença: a perspectiva dos Estudos Culturais. Petrópolis: Vozes, 2000.

. A identidade cultural na pós-modernidade. Rio de Janeiro: DP\&A, 1997.

HARVEY, David. Condição pós-moderna. São Paulo: Loyola, 1992.

HOUAISS, Antônio e VILLAR, Mauro Salles. Dicionário Houaiss da Língua Portuguesa. Rio de Janeiro: Objetiva, 200I.

HUMAN imperfect. Ballet Tanz, Berlim, n. 55092, p. 64-66, nov. 200I,

HUTCHEON, Linda; HUTCHEON, Michael. O corpo perigoso (The body dangerous: Salome dance). Revista Estudos Feministas, Florianópolis, SC, v. II, n. I, jan./Jun. 2003.

IANNITELLI, David. Steve Paxton e Lisa Nelson em São Paulo. Cadernos do GIPE-CIT, Salvador, n. 10, p. 62 -70. jun. 2000.

IANNITELLI, Leda M.. Dramaturgia corporal. In: CONGRESSO BRASILEIRO DE PESQUISA E PÓS-GRADUAÇÃO EM ARTES CÊNICAS (Memórias Abrace 5), 2. 2002, Salvador. Anais... Salvador: Associação Brasileira de Pesquisa e Pós-Graduação em Artes Cênicas - ABRACE, 2002, p. 538-543. 
IANNITELLI, Leda M.. Técnica da dança: redimensionamentos metodológicos. Repertório: Teatro e Dança, Salvador, ano 7, n. 7, p. 30-37, semestral 2004.

JAMESON, Fredric. Pós-Modernismo: a lógica cultural do capitalismo tardio. São Paulo: Ática, 1996.

JOHNSTONE, Christopher. Disability and identity: personal constructions and formalized support. In: Disability studies quartely, Fall, v. 24, n. 4, 2004. Disponível em: <http://dsq-sds.org/>. Acesso em: 27 out. 2004.

KATZ, Helena. Todo corpo é corpomídia. Com Ciência: Revista eletrônica de jornalismo científico, n. 74, 10 mar. 2006. Disponível em: <http://www.comciencia. $\mathrm{br} /$ comciencia/?section =8\&edicao $=1 \mathrm{I} \& \mathrm{id}=87>$. Acesso em: 15 abr. 2006.

. Um, dois, três... Dança é o pensamento do corpo. 1994. I9I f.Tese (Doutorado em Comunicação) - Programa de Estudos Pós-Graduados em Comunicação e Semiótica, Pontífice Universidade Católica - PUC, São Paulo, 1994.

KAYSER, Wolfgang. O grotesco. São Paulo: Perspectiva, 2003.

KUPPERS, Petra. Disability and contemporary performance. London: Routdlege, 2004.

LAPIERRE, André; AUCUTURIER, Bernard. A simbologia do movimento: psicomotricidade e educação. Porto Alegre: Artes Médica, 1986.

LE-QUÉAU, P. A arte da interpretação: introdução ao artigo de W. Dilthey sobre 'o nascimento da hermenêutica'. Tradução de P. Le-Quéau. [200-?]. Mimeo.

LEPECKI, André. Dance of Diferences. Ballet-Tanz, July 1998. First published in Ballet-Tanz Disponível em: <http://www.sarma.be/nieuw/critics/lepecki.htm>. Acesso em: 10 jan. 2005.

LIPOVETSKY, Gilles. A era do vazio. Lisboa: Relógio D’Água, 1989.

LOIZOS, Peter. Vídeo, filme e fotografias como documentos de pesquisa. In: BAUER, Martin, GASKELL, George (Ed.). Pesquisa qualitativa com texto, imagem e som: um manual prático. Petrópolis, RJ: Vozes, 2002.

LYOTARD, Jean-François. A condição pós-moderna. Rio de Janeiro: José Olímpio, 2000. . O Pós-moderno explicado às crianças. Lisboa: Dom Quixote, 1993.

MAFFESOLI, Michel. O conhecimento comum: compêndio de sociologia compreensiva. São Paulo: Brasiliense, 1983.

. Mediações simbólicas: a imagem como vínculo social. Revista Famaco, Porto Alegre, n. 8, jul. 1998, p. 7-14.

MATOS, Lúcia. Writing in the Flesh: body, Identity, Disability and Difference In: SHAPIRO, Sherry (ed). Dance in a world of change: reflections on globalization and cultural difference. Champaign: Human Kinetics, 2008, p. 7I-92.. 
MATOS, Lúcia. Cartografando múltiplos corpos dançantes: a construção de novos territórios corporais e estéticos na dança contemporânea. 2006. 2I4p. Tese (Doutorado em Artes Cênicas). Escolas de Dança e Teatro, Universidade Federal da Bahia.

Corpos que dançam: diferença e deficiência. In: Revista Diálogos Possíveis: revista da Faculdade social da Bahia - FSBA. Salvador, v. I, p. I77-|85. 2002.

. Múltiplos corpos dançantes: diferença e deficiência. In: BIÃO, Armindo et al. (Org.). Temas em contemporaneidade, imaginário e teatralidade. São Paulo: Annablume: Salvador: GIPE-CIT, 2000, p. 213-228.

. Múltiplos olhares sobre o corposurdo: a corporeidade do adolescente surdo no ensino da dança. 1998. I87f. Dissertação (Mestrado em Educação). Faculdade de Educação, Universidade Federal da Bahia, 1998.

MCLAREN, Peter. Multiculturalismo crítico. São Paulo: Cortez, 1997.

. Schooling the postmodern body: critical pedagogy and the politics of enfleshment. In: GIROUX, Henry (Ed.). Postmodernism, feminism and cultural politics: redrawing educational boundaries. New York: State University of New York Press, 1991.

MCNAMARA, J. Dance in the hermeneutic circle. In: FRALEIGH, Sondra \& HANSTEIN, Penelope (Ed.). Researching dance: envolving modes of inquiry. Pittsburgh, Pa: University of Pittisburgh Press, 1999. 368 p.

MENDES, João L. Pacheco. Entrevista com a Pulsar Companhia de Dança Contemporânea. Disponível em: <http://www.blocosonline.com.br/entrevista/pop_ artistas/pulsar.php>. Acesso em: 5 maio 2006.

MEYER, M.C. Psicomotricidade, memória corporal e educação. In: HERMANT, G. O corpo e sua memória. São Paulo: Manole, 1988, p. 89-94.

MINAYO, Maria Cecília de S. O desafio do conhecimento: pesquisa qualitativa em saúde. São Paulo: Hucitec; Rio de Janeiro: Abrasco, 1992.

MORIN, Edgar. Epistemologia da complexidade. In: SCHINITMAN, Dora Fried (Org.). Novos paradigmas, cultura e subjetividade. Porto Alegre: Artes Médicas, 1996, p. 274-289.

. O paradigma perdido: a natureza humana. Lisboa: Europa-América, |99|.

MURCHO, Desidério. A consciência do corpo. Entrevista realizada com António

Damásio. Disponível em: <http://www.criticanarede.com/entr_damasio.html>. Acesso em 5 de Abril de 2006.

NERI et al. Retratos da deficiência no Brasil. Rio de Janeiro: FGV, 2003. 
OLIVEIRA, Ana Cláudia. Sentidos do corpo ou corpo sentido? IN: SILVA, Ignácio (Org.). Corpo e sentido: a escuta do sensível. São Paulo: Editora da Universidade Estadual Paulista, 1996.

ORGANIZAÇÃO das Nações Unidas - ONU. Convenção sobre os Direitos das Pessoas com Deficiência. Tradução oficial - Brasil. Brasília, DF, 2006.

ORGANIZAÇÃO das Nações Unidas - ONU. Declaração de Montreal sobre Deficiência Intelectual. Montreal, CA, 2004.

PAREYSON, Luigi. Estética: teoria da formatividade. Petrópolis, RJ: Vozes, 1993.

PEALBART, PETER PÁL. Um mundo no qual acreditar. Disponível em: <http:// geocities.yahoo.com.br/guaikuru0003/deleuze_doss.html>. Acesso em: I2 nov. 2004.

PICK, Jane. Why have there been no great disabled artists? In: Disability Arts Magazine, v. 2, n. 4, p. 19-23, winter issue 1992.

PORTINARI, Maribel. História da dança. Rio de Janeiro: Nova Fronteira, 1989.

PRADO JR., Bento. Bento Prado Jr. analisa Deleuze. Entrevista concedida a Carlos Cássio. Folha de São Paulo, São Paulo, 2 jun. 1996. Disponível em: <http://geocities. yahoo.com.br/guaikuru0003/deleuze_doss.html>. Acesso em: 2 I mar. 2005.

PROGRAMA ARTE SEM BARREIRAS. Disponível em: <http://www.cultura.gov.br>. Acesso em: 12 nov. 2004.

ROSE, Diana. Análise de imagens em movimento. In: BAUER, Martin, GASKELL, George (Ed.). Pesquisa qualitativa com texto, imagem e som: um manual prático. Petrópolis, RJ: Vozes, 2002.

RUMOS DANÇA. Base de dados do RUMOS DANÇA do Itaú Cultural de 2000, 200 I e 2003. Disponível em: <http://www.itaucultural.org.br> Acesso em: 5 maio 2003.

RUSSO, Mary. O grotesco feminino: risco, excesso e modernidade. São Paulo: Rocco, 2000.

RUBIDGE, Sarah. Change and identity. In: PROCEEDINGS of Continents in Movement: new trends in dance teaching. Oeiras, PT: Universidade Técnica de Lisboa, Faculdade de Motricidade Humana, Departamento de Dança, 1998.

SACKS, Oliver. Um homem que confundiu sua mulher com um chapéu. São Paulo: Companhia das letras, 1997.

SASSAKI, Romeu K. Atualizações semânticas na inclusão de pessoas: deficiência mental ou intelectual? Doença ou transtorno mental? In: Revista Nacional de Reabilitação, São Paulo, no 9., n. 43, p. 9-10, mar./abr. 2005,

SCHLICHER, Susanne. O corpo conceitual: tendências performáticas na dança contemporânea. Tradução Ciane Fernandez. Repertório: Teatro \& Dança. Salvador, $200 \mathrm{I}$, ano 4, n. 5, p. 30-36 
SCHNITMAN, Dora (Org.). Novos paradigmas, cultura e subjetividade. Porto Alegre: Artes Médicas, 1996.

SCHÖPKE, Regina. Por uma filosofia da diferença: Gilles Deleuze, o pensador nômade. Rio de Janeiro: Contraponto; São Paulo: Edusp, 2004.

SCHULMAN, Norma. O Centre for Contemporary Studies da Universidade de Birmingham: uma história intelectual. In: SILVA, Tomaz T. (Org.). O que é, afinal, Estudos Culturais? Belo Horizonte: Autêntica, 1999.

SCHULMAN, Nathalie. Paradoxos do intérprete e de suas interpretações. In: DOSSIÊ: Dança e dramaturgia. São Paulo: PUC, [200-]. Mimeo.

SHAKEASPEARE, Tom. Disability, identity and difference. In: BARNES, Colin; MERCER, Geof. Exploring the divide. England: Leeds, 1996, p. 94-II 3.

SILVA, Tomáz T. (Org.). Identidade e diferença: a perspectiva do Estudos Culturais. Petrópolis: Vozes, 2000. . (Org.). O que é, afinal, Estudos Culturais? Belo Horizonte: Autêntica, 1999.

SILVA, Ignácio (Org.). Corpo e sentido: a escuta do sensível. São Paulo: Editora da Universidade Estadual paulista, 1996.

SKLIAR, Carlos (Org.). Atualidade da educação bilíngüe para surdos. Porto Alegre: Mediação, v. I e 2, 1999.

STINSON, Susan. W. Body of knowledge. Educational Theory, Champaign, USA, ano 45 n. I, p. 43-45, winter, 1995.

SODRÉ, Muniz; PAIVA, Raquel. O império do grotesco. Rio de Janeiro: Mauad, 2002.

SONTAG, Susan. Contra a interpretação. PortoAlegre: LMP, 1987.

TAYLOR, Sherry. Dança em uma época de crise social: em direção a uma visão transformadora de dança-educação. Revista Comunicação e Artes, São Paulo, v. 17 n. 28, p. 65-74, jan./abr. 1994.

THE HUMAN Rights Act 1998. In: Disability Alliance Organization. Disponível em: <www.disabilityalliance.org. > Acesso em: 2 fev. 2010.

THOMAS, Helen. Dance: modernity and culture. London: Routledge, 1995.

TUCHERMAN, leda. Breve história do corpo e de seus monstros. Lisboa: Vega / Passagens, 1999.

UFBA. DEPOIMENTO de Fátima Daltro sobre contact improvisation. 2004. Disponível em: http://www.facom.ufba.br/com024/contact/depoimento2.html. Acesso em: 10 fev. 2006.

VÁSQUEZ, Adolfo Sánchez. Convite À Estética. Rio de Janeiro: Civilização Brasileira, 1999. 
VILLAÇA, Nízia; GÓES, Fred; KOSOVSKY, Ester (Org.). Que corpo é esse? RJ: Mauad, 1999.

VILLAÇA, Nízia; GÓES, Fred. Em nome do corpo. Rio de janeiro: Rocco, 1998.

WHITE, Hayden. Bodies and their plots. In: FOSTER, Susan L. (Ed.). Choreographing history. Bloomington and Indianapolis: Indiana University Press, 1995.

WOLFF, Janet. Reinstating corporeality: feminism and body politics. In: DESMOND, Jane C. (Ed.). Meaning in motion: new cultural studies of dance. Durham and London: Duke University Press, 1997.

\section{ENTREVISTAS}

CIA DE DANÇA EKILÍBRIO. Entrevista coletiva concedida em julho 2005, na Ekilíbrio, Juiz de Fora, MG. Juiz de Fora, MG: [s. n.], 2005.

GRUPO X. Entrevista coletiva concedida em ago. 2005, na Escola de Dança da UFBA, em Salvador, Ba. Salvador, BA: [s. n.], 2005.

LIMITES CIA DE DANÇA. Entrevista coletiva concedida em julho 2005, no Shopping Cristal Plaza, em Curitiba, PR. Curitiba, PR: [s. n.], 2005.

PULSAR CIA DE DANÇA. Entrevista coletiva concedida em set. 2005, na Faculdade Angel Vianna, no Rio de Janeiro, RJ. Rio de Janeiro, RJ: [s. n.], 2005. 



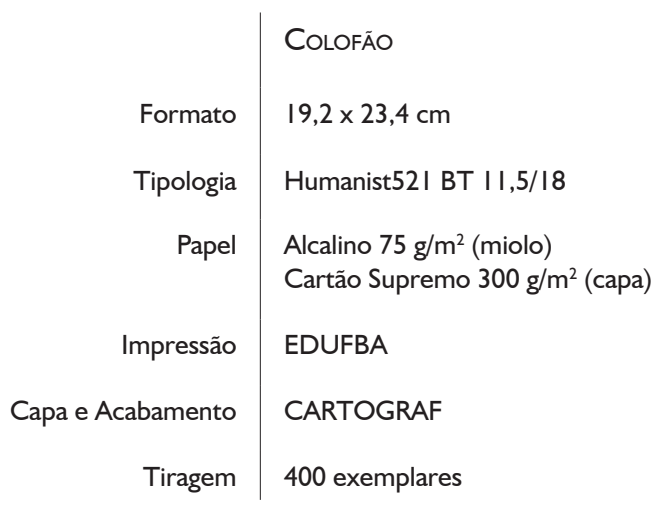




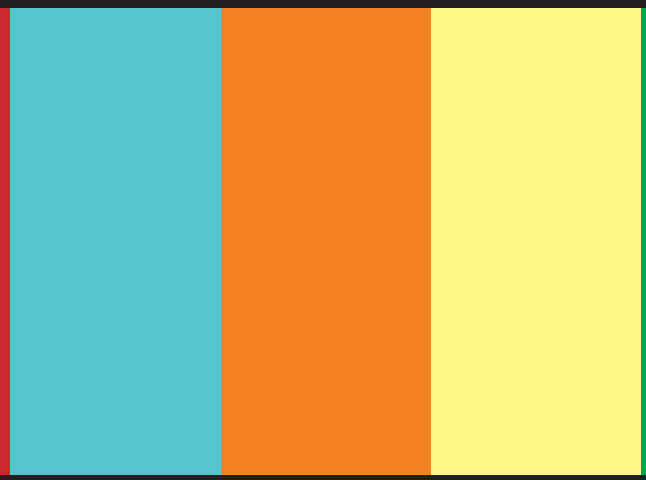

A Coleção Pesquisa em Artes é direcionada à publicação de textos que problematizam aspectos diversos dos fazeres artísticos e suas complexas relações com a sociedade, a contemporaneidade e o conhecimento.

Abranje, particularmente, pesquisas nas áreas de Dança, Música, Teatro, Artes Plásticas, que são aéreas de tradição e referência na Universidade Federal da Bahia. 